\title{
The Dynamic Life of an Oceanic Plate
}

\author{
Fabio Crameri ${ }^{1}$, Clinton P. Conrad ${ }^{1}$, Laurent Montési ${ }^{2}$, Carolina R. \\ Lithgow-Bertelloni ${ }^{3}$ \\ ${ }^{1}$ Centre for Earth Dynamics and Evolution (CEED), University of Oslo, Norway \\ ${ }^{2}$ Department of Geology, University of Maryland, College Park, USA \\ ${ }^{3}$ Department of Earth Sciences, University College London, United Kingdom
}

\begin{abstract}
As the Earth's primary mode of planetary cooling, the oceanic plate is created at mid-ocean ridges, transported across the planet's surface, and destroyed at subduction zones. The evolution of its buoyancy and rheology during its lifespan maintains the coherence of the plate as a distinct geological entity and controls the localised deformation and vertical material exchange at plate boundaries, which enables the horizontal ocean-plate movements. These motions intimately link the oceanic plate to the overarching overturn of Earth's mantle: The plate forms out of rising mantle material at spreading ridges; it cools the Earth's interior as the cold thermal boundary layer to mantle convection; and its sinking portions drive not only the plate itself but also dominate global flow in the mantle. We scrutinise here the entire life cycle of the oceanic plate, starting with its birth at the mid-ocean ridge, including the thermal, rheological, and chemical conditions of initiation, followed by plate maturation as it ages and cools while crossing the seafloor, and finishing with the dynamics of plate destruction as it retires at the subduction zone to become a deeper part of Earth's convective system. We find that the full range of dynamic behaviour of the oceanic plate, including its forcing and overall framework within Earth's convecting system, is not fully captured by the existing concept of Plate Tectonics, which describes solely the horizontal surface kinematics of all plates. Therefore, we introduce a more specific and at the same time more integral concept named "Ocean-Plate Tectonics" that more specifically describes the dynamic life of the oceanic plate and accounts for the knowledge gained during the past fifty years. This "OceanPlate Tectonics" must have emerged on Earth at least 1 Billion years ago, and dominates Earth's dynamics today.
\end{abstract}


Keywords: Oceanic Plate, Plate Tectonics, Mantle Convection, Ocean-Plate Tectonics, Mid-Ocean-Ridge, Seafloor, Subduction

\section{Contents}

1 Overview 3

2 Ocean-Plate Formation $\quad \mathbf{6}$

2.1 The building blocks: Spreading, upwelling, and melting . . . . 7

2.1.1 Kinematics of spreading . . . . . . . . . . . . . 7

2.1.2 Upwelling .................. . . . . 8

2.2 Melting processes .................. . . . . 11

2.2.1 Melt generation . . . . . . . . . . . . 11

2.2.2 Melt focusing . . . . . . . . . . . . . . . . . . . 12

2.3 Preparing the plate: Near-axis modification . . . . . . . . . 14

2.4 Spreading-ridge inheritance . . . . . . . . . . . . . . 17

3 Ocean-Plate Cooling $\quad 19$

3.1 Heat flow and subsidence of the oceanic plates . . . . . . . 20

3.2 Basin evolution over geologic time . . . . . . . . . . . . 22

3.3 Preparation for subduction . . . . . . . . . . . . . . . 24

4 Ocean-Plate Destruction $\quad \mathbf{2 5}$

4.1 Necessities for subduction . . . . . . . . . . . . . . 26

4.1.1 Why the plate sinks . . . . . . . . . . 26

4.1.2 Will the plate sink? . . . . . . . . . . . . 26

4.2 Sinking-plate characteristics . . . . . . . . . . . . . . . . 29

4.3 The dynamic diversity of subduction . . . . . . . . . . . 32

4.4 Consequences of the sinking plate . . . . . . . . . . . . . 36

4.4.1 Consequences of the shallow slab . . . . . . . . 36

4.4.2 Consequences of the deep slab . . . . . . . . . . . 40

5 Ocean-Plate Tectonics $\quad 41$

5.1 A more specific, more integral concept . . . . . . . . . . . 41

5.2 Emergence . . . . . . . . . . . . . . . . . 43

5.3 Closing . . . . . . . . . . . . . . . . . . 44 


\section{Overview}

An oft-repeated phrase defines our planet as a heat engine. It is perhaps tired, but nonetheless true. Our planet loses the heat of formation and that generated by radioactivity every day. The physical processes by which that heat is transferred, from crystallisation of the inner core due to secular cooling, fluxing of heat into the mantle, the transport of heat to the surface by convection currents, and heat loss by conduction at ridges, define the dynamics of our planet. The most clearly visible surface manifestation of this process is the oceanic plate: it is the engine that drives plate tectonics and the top thermal boundary layer of Earth's convecting system.

Oceanic plates outperform the bottom boundary layer in terms of heat transfer and contain most of the thermal energy driving convection, which is deposited there by the cooling of the planet (e.g., Zhong, 2006). The oceanic plate also contains, by virtue of its formation, the engine of chemical differentiation that melting of the mantle at the ridge enables. In short, oceanic plates are the engine of continuous generation of chemical and thermal differentiation of the planet.

Partial melting of peridotite at shallow depths (Section 2) creates a basaltic crust and its complementary residuum, a depleted mantle. The relative thickness of these layers is a function of Earth's potential temperature and the degree of partial melt. From petrological, geochemical, and geophysical constraints (Klein and Langmuir, 1987; Workman and Hart, 2005; Dalton et al., 2014), we infer that $1600 \pm 50 \mathrm{~K}$ is the potential temperature of the mantle. The resulting intersection of that geotherm with the melting curve of peridotite produces 10-20\% partial melt over roughly $80 \mathrm{~km}$ depth, which results in $\sim 7 \mathrm{~km}$ of basaltic crust. Left behind is a complementary residuum of depleted mantle (e.g., harzburgite) that comprises a layer $4-6$ times thicker than the melting product. The rest of the oceanic plate that composes the oceanic lithosphere is the thermally accreted peridotite that may be cold enough to be mechanically strong. That base is thermally defined by the $1600 \mathrm{~K}$ isotherm that nearly outcrops at the ridge and defines the potential temperature of normal, if not average, mantle.

What is described above has set the canonical definition for the thickness of the oceanic plate from birth to death. It is also that potential temperature and the difference with the temperature at the Earth's surface that sets the thermal content of the oceanic plate and the thermal energy of Earth's convecting system. This is equivalent to a gravitational energy per unit 
volume of $\sim 3 \times 10^{9} \mathrm{~J} / \mathrm{m}^{3}$ and a density contrast of $\delta \rho>2 \%$ with respect to the underlying mantle. This would encapsulate most of the energy in the mantle-convection system, if the mantle was purely heated by radioactive decay. However, core cooling can be a significant contributor, perhaps as much as $50 \%$ of the total energy budget (Lay et al., 2008), making the bottom boundary layer almost as important as the oceanic plate.

The thermal contrast between the interior of the Earth and its surface is distributed over a finite thickness as the plate cools, a plate thickness that grows as the plate moves away from the ridge. As the plate ages, it interacts with transform faults and develops fracture zones, and it is pinpricked by magma generating seamounts and volcanoes that load it and deform it. In other words, during its growth phase, the oceanic plate is fundamentally altered in composition by magmatism and, most importantly, by water interacting with the basaltic crust and uppermost mantle as well as plate deformation, cracking, and fracturing. These chemical and mechanical alterations fundamentally modify the nature of the oceanic plate after formation so that it becomes rheologically heterogeneous.

This suggests a different definition of the thickness or base of the oceanic plate. This one is not defined thermally by the $1600 \mathrm{~K}$ isotherm, but rather by mechanical strength, which may be most useful in the context of the platemantle system. That is, the plate is defined as that part of the lithosphere mechanically strong enough not to be convectively unstable. We may envision the plate as consisting of the crust and the depleted mantle (and perhaps the very coldest undepleted mantle), both cold enough and rheologically distinct from what is underneath and governed by a rheology stiff enough to remain coherent throughout the remaining lifetime of the plate.

During the partial melting process, we expect water to move from the solid to the melt (Asimow et al., 2001), and hence be accumulated into the crust, while depleting the residuum of water, making it drier and stronger (Karato and Jung, 1998). The oceanic plate would then consist, from its very birth, of a wetter weaker crust, underlain by a drier, stronger, chemically depleted core that is in turn underlain by a cold, but less strong, undepleted mantle. The process of cooling and growth of the oceanic lithosphere with hydrothermal cooling at the ridge axis and interactions at transforms faults and fracture zones would further alter the hydration of the crust and perhaps plate as a whole, affecting the plate rheology. This process would be further aided by compositional alteration and mechanical loading by seamounts. This gives us a picture of an oceanic plate that not only contains a great thermal en- 
ergy and is compositionally differentiated, but one with large variations in mechanical properties.

The thermally, compositionally, and mechanically heterogeneous oceanic plate reaches its ultimate fate at subduction zones where its properties, particularly rheology, determine subduction-zone dynamics (Garel et al., 2014), the morphology of the plate (slab) in the mantle (e.g., Royden and Husson, 2006), and, most important for society, the coupling with the overriding plate, which may significantly impact earthquake hazards (e.g., Herrendorfer et al., 2015). Indeed, the very weakness of the crust seems essential for subduction (Lenardic and Kaula, 1994; Gerya et al., 2008; Crameri and Tackley, 2015).

A momentous phenomenon happens during the birth of the oceanic plate. After eruption, the basaltic lavas acquire information about the Earth's magnetic field as they cool below the Curie temperature. In doing so, oceanic plates become the most accurate recorders of Earth's kinematic history. Without this record, we would not have been able to develop the plate tectonics paradigm or connect Earth's internal dynamics to surface processes (Vine and Matthews, 1963). It is in this kinematic record, and its implications for both plate tectonics (Seton et al., 2012) and the link between plate history and mantle dynamics (e.g., Torsvik et al., 2014; Domeier et al., 2016), that Trond Torsvik's contributions have been fundamental to the fields of both Paleomagnetism and of Geodynamics. It seems fitting then to dedicate this paean to the oceanic plate to him.

The oceanic plate, from its formation at the ridge to its destruction at subduction zones, is the engine that drives plate tectonics, even though largescale mantle upwellings may contribute on regional scales (Lithgow-Bertelloni and Silver, 1998; Cande and Stegman, 2011; Becker and Faccenna, 2011) or by enhancing global convection cells that are primarily organised by downwellings (Steiner and Conrad, 2007; Faccenna et al., 2013). Plate formation by partial melting of mantle rocks and their subsequent cooling, leads to a compositionally differentiated boundary lithosphere that carries thermal, rheological and chemical heterogeneity back into the convecting system. It is this heterogeneity that we image with seismic waves. The details of these processes, the formation at ridges, the growth via cooling as the plate spreads, and its destruction at subduction zones, are the subject of the subsequent sections of this paper and are illustrated in Figure 1. Our motivation is to review these three stages of the oceanic plate and to illustrate the fundamental nature of the oceanic plate for plate tectonics (and mantle convection) on Earth, the only planet where oceanic plates are found. 


\section{Ocean-Plate Formation}

A central element of the global tectonic regime of our planet is the MidOcean Ridge (MOR) system, where plates diverge and where new oceanic lithosphere, including its crust, is formed (e.g., Parsons, 1981). A MOR is where the Earth turns itself inside out and gives birth to the oceanic plate. Spreading ridges are crucial to the Earth system: Magmatic activity and faulting at the ridge axis combine to drive hydrothermal circulation, which chemically processes seawater, focuses heat to hydrothermal vent sites, where abundant biological activity can be found, and precipitates valuable mineral deposits (Wolery and Sleep, 1976; Humphris et al., 1995; Lowell et al., 2008). With regards to plate tectonics, a MOR acts to initialise the oceanic lithosphere and prepare it for its later evolution (e.g., Williams and Von Herzen, 1974; Stein and Stein, 1994). The nascent plate must be described in terms of its dynamics, which cover thermal and mechanical processes, and its structure, which includes chemical composition and zones of mechanical damage that are permanently inscribed into the evolving lithosphere.

At lithospheric scales, a MOR can be seen as a rather simple system because preexisting conditions can essentially be ignored: To first order, ridges are in steady state and continually renewed; mantle rises up and melts; the melt collects to form the crust; the thermal lithosphere grows progressively as the plate cools; plate motion evacuates the growing lithosphere, allowing the process to continue ad infinitum; there is no inheritance. On the other hand, the ridge is a rapidly evolving system characterised by strong lateral gradients, both perpendicular and parallel to the ridge axis (Lin and Morgan, 1992; Magde et al., 1997; Sinha and Evans, 2004): Transform faults are an important source of complexity (Morgan and Forsyth, 1988; Behn et al., 2007; Gregg et al., 2009; Weatherley and Katz, 2010; Bai and Montési, 2015); melting and melt extraction are still not fully understood (Kelemen et al., 1997; Katz, 2008; Keller et al., 2017); recent studies have revealed traces of preexisting lithosphere (Torsvik et al., 2014, 2015).

Here, we focus on these recent developments. After a quick overview of the fundamental geodynamic building blocks active at MORs, we discuss how they interact with each other and influence melt extraction, what the structure of the plate that exits the MOR system is, and finally review the evidence for some degree of inheritance at MORs. 


\subsection{The building blocks: Spreading, upwelling, and melting}

\subsubsection{Kinematics of spreading}

The first-order kinematics of a MOR were first identified after geophysical investigations revealed stripes of normal or reverse magnetic polarity on the seafloor. Each polarity reversal marks a discrete time during which the oceanic crust formed. The symmetry of reversal patterns about the ridge axis is most easily explained by the plate carrying away newly formed oceanic crust. Although it had previously been proposed that MORs are the location where plates move away from one another (Dietz, 1961; Hess, 1962), the link with a magnetic time scale (Vine, 1966) made it possible to reconstruct former plate motions by removing the oceanic plate formed since a given epoch (e.g., Torsvik and Cocks, 2016b).

Unlike what is commonly described in textbooks, seafloor spreading is rarely perfectly symmetric. Instead, one plate moves away from the ridge axis slightly faster than the other (Müller et al., 1998; Müller et al., 2008). If the velocities of each plate away from the ridge axis are $V_{1}$ and $V_{2}$, the spreading rate, or plate-divergence rate, is $V_{D}=V_{1}+V_{2}$ (see Figure 2). Depending on the reference frame considered, the asymmetry of spreading can be regarded either as the difference in plate motion with respect to the ridge axis or as the velocity at which the ridge migrates away from a fictitious point remaining halfway between the two plates: $V_{R}=\left(V_{1}-V_{2}\right) / 2$. Globally, the degree of asymmetry, defined here as $\left|V_{1}-V_{2}\right| /\left(V_{1}+V_{2}\right)$, is $13 \pm 10 \%$, and it rarely exceeds $20 \%$ (Figure $3 \mathrm{a}$ ). The most asymmetric segments also tend to be the slowest.

The spreading rate, which can vary from $V_{D} \approx 10 \mathrm{~mm} / \mathrm{yr}$ to $V_{D} \approx 150$ $\mathrm{mm} / \mathrm{yr}$, is associated with systematic variations in ridge axis morphology and along-axis segmentation (Schouten et al., 1985; Macdonald et al., 1988). Most ridges are broken into segments separated by transform faults parallel to the spreading direction (see Figure 1). Opening obliquely to the azimuth of transform faults requires the transform fault to be under transtension or transpression, or to rotate at an angle from the ridge axis, and is therefore not favoured. Seismic investigations have suggested that the uppermost mantle may move at an angle from surface plate motions (Toomey et al., 2007). Although the cause for this "skew" remains a mystery, it is possible that the shear it imposes on the ridge axis causes reorientation of ridge segments and formation of new discontinuities (Van der Beek et al., 2016).

When the spreading rate decreases to the range of ultraslow spreading 
centres $\left(V_{D} \leq 15 \mathrm{~mm} / \mathrm{yr}\right)$, transform faults become increasingly rare (Grindlay et al., 1998; Dick et al., 2003; Michael et al., 2003). Instead it becomes increasingly common for the ridge axis to be oblique to the spreading-normal direction (Taylor et al., 1994; Dick et al., 2003). Such axes are under transtension, which can be sustained over long periods in the absence of major ridge axis discontinuities. From a structural and thermal viewpoint, it is useful to decompose plate motion into a ridge-normal, or effective, spreading rate, $V_{E}=\frac{1}{2} V_{D} \sin \gamma$, and a ridge-parallel velocity, $V_{S}=\frac{1}{2} V_{D} \cos \gamma$, where $\gamma$ is the obliquity angle, as the shear component induces a fundamentally different flow field than the divergence (Montési and Behn, 2007, Figure 2).

Few ridges display an obliquity angle, $\gamma$ (see Figure 2), larger than $30^{\circ}$ : High obliquity is most commonly observed at either ultraslow or ultrafast spreading centres (Figure 3b). This may be an effect of the energy partitioning between spreading centre and transform faults (Stein, 1978). Alternatively, this may reflect the absence of well-developed transform faults in either endmembers: Segmentation at ultraslow ridges is expressed by changes in ridge azimuth (Dick et al., 2003) and at ultrafast ridges by overlapping spreading centres and microplates (Macdonald, 1998), which can accommodate transtension by rotating. In terms of instantaneous kinematics, there is only a semantic difference between a high obliquity ridge and a transtensional transform fault (Taylor et al., 1994), but it may be implied, for the former, that sufficient extension has taken place, so that new lithosphere and oceanic crust is generated.

\subsubsection{Upwelling}

As the plates diverge, material rises from the Earth's interior and fills the otherwise opening gap between the plate (Figure 1). Drawing on the fluid mechanics solution for corner flow (Batchelor, 1967), McKenzie (1969) described the mantle as a fluid driven by the motion of two rigid plates. The solution was later generalized so that the base of the plate can have a slope (Spiegelman and McKenzie, 1987), which approximates the base of the actual plate (Lachenbruch, 1976). Additionally, Montési and Behn (2007) showed that, in the case of an oblique spreading centre, the upwelling rate is controlled solely by the effective spreading rate, $V_{E}$. Solutions for corner flow with a power-law rheology are also available (Fenner, 1975), even though they have been applied principally to subduction zones, not mid-ocean ridges (Tovish et al., 1978). The corner flow problem can be solved analytically for an isoviscous, Newtonian fluid. For a symmetric ridge, the maximum 
upwelling rate is directly underneath the axis and has value of $V_{z}^{0}=V_{E} \frac{1-\cos \beta}{\beta-\sin \beta}$, where $\beta$ is the angle between the base of the lithosphere on either side of the axis. The upwelling rate is less than the spreading rate if the slope of the lithosphere is horizontal $\left(\beta=2 \pi, V_{z}^{0}=2 V_{E} / \pi\right)$ but increases when the slope of the lithosphere is steeper. The upwelling rate, $V_{z}^{0}$, even exceeds the spreading rate, $V_{E}$, if $\beta$ is less than $\sim 138^{\circ}$, that is, if the lithosphere slope is more than $\sim 21^{\circ}$. In truth, the slope of the lithosphere depends on the thermal structure and varies with distance from the axis and with spreading rate (Figure 4). The analytical solution shows the upwelling scales with the effective spreading and is enhanced by the steep lithospheric slopes that may be expected at slow spreading centres.

A separate source of upwelling comes from low-density anomalies, or mantle plumes (Lin et al., 1990; Sparks et al., 1993). Whether thermal or compositional in origin, a low-density region can rise as a plume or a Stokes sphere and can change the thermal regime of the axis (Ruedas et al., 2004). The slope of the lithosphere (Ribe, 1996; Ito et al., 1997; Albers and Christensen, 2001; Ito et al., 2003; Gassmöller et al., 2016) and the upwelling flow generated by ridge spreading (Jellinek et al., 2003) should focus plumes towards the ridge axis. As a plume can weaken the lithosphere elsewhere and favour the initiation of a new ridge above it (Gerya et al., 2015), ridges can migrate, typically by jumps, to maintain their position above mantle plumes and to maximise plume-ridge interaction (Schilling et al., 1985; Wilson and Hey, 1995; Hardarson et al., 1997; Mittelstaedt et al., 2011; Howell et al., 2014). The clearest indication that mantle plumes can influence a MOR is found in the presence of elevated ridge segments, like Iceland, the Azores, or parts of the Cocos-Nazca spreading centre, indicating increased material flux (Vogt, 1971; Schilling, 1973, 1991; Canales et al., 1997; Gente et al., 2003; Mittelstaedt et al., 2012; Graham et al., 2014). Geophysical evidence for onaxis plumes at the East Pacific Rise includes a narrow electrical conductivity anomaly below the axis (Baba et al., 2006) and rapid near-axis thickening of the lithosphere (Harmon et al., 2009). However, this upwelling may not have a deep origin, and could be driven by the buoyancy of the melt present in the upwelling mantle (Eilon and Abers, 2017). As the divergence-related flow field scales with spreading rate but the plume-related upwelling scales with density anomaly, independent of spreading rate, it stands to reason that slow-spreading ridges should be more sensitive to plume influence than fastspreading ridges (Lin and Morgan, 1992), even though fast-spreading ridges may be more effective at attractive plumes. 
The thermal structure of the oceanic plate is controlled principally by its age (Stein and Stein, 1994; McKenzie et al., 2005). At the ridge axis, however, the upwelling of warm mantle introduces heat into the MOR system. The thermal structure at the MOR is therefore controlled by a balance between advection, especially upwelling, and conduction, with additional contributions from the latent heat released upon melting (e.g., Sleep, 1975). The thermal length scale $L_{T}=\kappa / V_{z}^{0}$, where $\kappa$ is the thermal diffusivity, describes the transition from conduction-dominated to advection-dominated heat transfer. It can be used to provide a quick estimate of the lithosphere thickness on-axis $z_{L} \approx 5 L_{T}$ (Montési and Behn, 2007). For an isoviscous ridge, the on-axis lithosphere thickness is inversely proportional to the effective spreading rate, and varies from $\sim 1 \mathrm{~km}$ to $30 \mathrm{~km}$ between ultrafast and ultraslow spreading centres, respectively. However, precise values must take into account many complicating and often competing factors (Braun et al., 2000; Sleep and Warren, 2014) including the effects of temperatureand strain-rate-dependent viscosity, near-surface cooling from hydrothermal circulation, the cooling effects of melting, and heat advection with melt transport (Figures 4 and 5).

At fast and intermediate spreading rates $\left(V_{E} \geq 33 \mathrm{~mm} / \mathrm{yr}\right)$, this estimate perhaps surprisingly places the base of the lithosphere within the crust (e.g., Hebert and Montési, 2010). The additional heat flux from the melt input makes the lithosphere thinner than this value. The lithosphere at a fast spreading centre is therefore better regarded as the top of a crustal magma chamber, only $\sim 1 \mathrm{~km}$ below the seafloor (Detrick et al., 1993).

At the slowest ridges, this estimate places the base of the lithosphere to $\sim 30 \mathrm{~km}$. The slope of the lithosphere increases the upwelling rate, which would thin the lithosphere. However, hydrothermal circulation increases heat loss in the first few kilometres near the surface (Behn et al., 2004; Sinha and Evans, 2004). This effect may be especially important at ultraslow spreading centres, where brittle failure reaches significant depths (Schlindwein and Schmid, 2016), and would thicken the lithosphere. These processes counteract each other so that precise value for on-axis lithosphere thickness requires a fully coupled model, but eventually may not be too different from the analytical estimate to $5 \kappa / L_{T} \approx 30 \mathrm{~km}$ : seismic activity reaches depths of at least $31 \mathrm{~km}$ at the ultraslow Southwest Indian Ridge (Schmid and Schlindwein, 2016). 


\subsection{Melting processes}

\subsubsection{Melt generation}

The main cause of melting at a MOR is decompression in the upwelling mantle. For a "typical" mantle potential temperature of $1350^{\circ} \mathrm{C}$ (Putirka et al., 2007; Dalton et al., 2014), the dry solidus is reached at about $80 \mathrm{~km}$ depth (Figures 4 and 5). As mantle progressively decompresses, up to about $20 \%$ of it melts (Langmuir et al., 1993). How much and how fast melt is produced remains poorly understood, as both the solidus (Hirschmann, 2000; Sarafian et al., 2017) and the rate at which melt is produced are still debated. Early models have assumed a linear variation between solidus and liquidus (Reid and Jackson, 1981), while a nonlinear function, in which melting may become more effective as it proceeds, was favoured by Katz et al. (2003). Detailed petrology-based models have also been developed (Niu and Batiza, 1991; Kinzler and Grove, 1992; Asimow et al., 2001; Behn and Grove, 2015) but often assume a melt production rate. Although it is possible to draw conclusions regarding mantle temperature, melting regime and other similar aspects by modelling geochemical data (McKenzie and Bickle, 1988; Shaw et al., 2010; Gale et al., 2013), caution is required in interpreting these results as long as the laws that govern melting at MORs are not better understood.

Several aspects of melting at MORs are well known, though. For example, melting is eutectic: The principal minerals present in the upper mantle, olivine and pyroxene, start to melt at much lower temperatures when combined than when separated (Langmuir et al., 1993). However, as clinopyroxene is preferentially incorporated into the melt, the solid composition changes as melting proceeds (Walter et al., 1995; Longhi, 2002). Eventually, after $\sim 15 \%$ to $20 \%$ melting clinopyroxene is exhausted and melting rate decreases dramatically (Katz et al., 2003, Figure 5).

One major difference between melting in the laboratory and melting in a natural MOR environment is that experiments are conducted as a closed system, whereas in nature melt rapidly separates from the solid residuum (Spiegelman, 1993). Although $15 \%$ melting is expected in most calculations due to decompression alone, geophysical methods detect only 1 to $2 \%$ melt (Team, 1998; Evans et al., 1999; Eilon and Abers, 2017). The rest is extracted quickly, so that the actually melt content, or porosity $\phi$, is much smaller than the degree of melting, $F$.

Two factors allow this rapid melt transport. First, melt appears to efficiently wet solid grains, leading to an effective microscopic channel network 
(Zhu et al., 2011; Miller et al., 2014). Second, melt is likely to be distributed in subvertical melt channels due to one of several mechanisms. For example, as melt rises and encounters lower and lower pressures, it should react with the surrounding solid grains, dissolving orthopyroxene and precipitating olivine, and increasing porosity (Kelemen et al., 1995). As this increases permeability and melt transport rate, the process becomes unstable, leading to localised channels, the size of which is controlled by the balance between reaction and horizontal melt transport into the channel (Spiegelman et al., 2001). These melt channels are easily triggered by unavoidable compositional heterogeneities in the upwelling mantle (Keller and Katz, 2016) and are able to form despite the disrupting effect of the solid mantle flow (Keller et al., 2017). Melt-rich channels may also develop using feedbacks between melt contents and viscosity, buoyancy, and temperature (Stevenson, 1989; Butler, 2009; Hewitt and Fowler, 2009). How all of these phenomena interact remains to be studied, but it is clear that melt is very effectively extracted from the upwelling, decompressing mantle. The effect of melt influx at the base of the on-axis lithosphere also remains to be understood, but it will likely thin the lithosphere due to the heat accompanying the melt (Sleep and Warren, 2014). This effect would be most important at slow and ultraslow ridges where the lithosphere is thicker than the crust.

\subsubsection{Melt focusing}

With such uncertainties on the melting process, it is not surprising that the actual volume of melt produced at a mid-ocean ridge also remains uncertain. The issue is compounded by uncertainties regarding the mode of melt extraction. If only the vertical transport described above were active, melt would be delivered on the seafloor over distances of several hundred kilometres. Instead, crustal thickness reaches its final value within 1 or 2 $\mathrm{km}$ distance from the ridge axis (e.g., Vera et al., 1990), implying intense focusing of the melt towards the axis (Kelemen et al., 1997).

Many ways of focusing melt towards the axis have been proposed over the years. Divergence at the axis is, for example, associated with a pressure low, which might suck melt towards the axis (Spiegelman and McKenzie, 1987; Morgan, 1987). However, this effect depends on mantle viscosity and is probably effective only over $10 \mathrm{~km}$ or so. The buoyancy of melt-rich material near the axis may generate a dynamic upwelling (Buck and Su, 1989). However, the efficiency of melt transport precludes the accumulation of enough melt to generate a strong diapir (Barnouin-Jha et al., 1997). Hart (1993) suggested 
that melt channels might coalesce and form a fractal tree that delivers melt only to the ridge axis, but numerical experiments and field observations suggest that the rate at which channels merge is not high enough (Braun and Kelemen, 2002). One possibly successful way to focus melt towards the ridge axis is to take advantage of the shear experienced by the mantle as it rises and turns following corner flow stream lines. Laboratory and numerical experiments have shown that melt can collect in melt-rich bands at an angle from the shear direction (Holtzman et al., 2003; Kohlstedt and Holtzman, 2009). These melt bands may be oriented in the MOR mantle in such a way that melt moves preferentially towards the ridge axis (Katz et al., 2006).

A particularly successful model of melt focusing was proposed by Sparks and Parmentier (1991): They argued that melt actually rises predominantly vertically but that, as it enters the lithosphere far from the axis, it crystallises fast enough to form an impermeable barrier. Such a barrier is likely associated with crystallisation of pyroxene \pm plagioclase (Kelemen and Aharonov, 1998) and nearly follows an isotherm along the base of the lithosphere (Hebert and Montési, 2010). Thus, melt can travel in a decompaction channel immediately below the barrier and be guided towards the ridge axis. Although direct evidence of the permeability barrier and decompaction channel is scant, this model predicts variations in crustal thickness related to ridge segmentation that compare well with observations (Montési et al., 2011; Hebert and Montési, 2011; Bai and Montési, 2015). Finally, it is possible that a deeper barrier exists at greater depth, where permeability is reduced because the shear associated with corner flow reduces grain size (Turner et al., 2015) or because of variations in compaction pressure when the mantle is treated as a non-Newtonian fluid (Turner et al., 2017). The melt content distribution predicted by these last two studies matches well electromagnetic images of melt distribution at the East Pacific Rise (Key et al., 2013): They show accumulation of melt along horizons dipping roughly at $45^{\circ}$ with melt contents reaching $10 \%$.

These processes, focusing melt towards the ridge axis, work against the flow of mantle. As they are all more effective close to the axis, whether because more melt is produced or the decompaction channel has a steeper slope, there is a critical distance from the axis where melt focusing is possible. In the models of Keller et al. (2017), that distance is roughly $120 \mathrm{~km}$ for a spreading rate of $3 \mathrm{~cm} / \mathrm{yr}$. The focusing distance may decrease as spreading rate increases due to stronger mantle flow and flatter isotherms. It may, for example, reach $75 \mathrm{~km}$ at the fast spreading East Pacific Rise (Gregg et al., 
2009) and only $20 \mathrm{~km}$ at the ultraslow spreading Gakkel ridge (Wanless et al., 2014). The assumptions behind each of these numbers are so different, though, that it is difficult to know how compatible these estimates may be.

Figure 6 compares the crustal thickness predicted at MOR to the measurements compiled by White et al. (2001). A melt extraction distance of $50 \mathrm{~km}$ matches the observations well, with crustal thicknesses around $7 \mathrm{~km}$ except for slow effective spreading rates of $V_{E} \leq 10 \mathrm{~mm} / \mathrm{yr}$. Longer extraction widths produce excessive crust, which could be compensated with lower mantle temperature or taking into consideration melt lost by crystallisation during melt extraction (Ghods and Arkani-Hamed, 2000). However, modelling the chemistry of mid-ocean ridge basalts favours temperatures as in this calculation or higher (Behn and Grove, 2015). The scatter in the data may be related to local variations in mantle temperature, which may reach $\pm 200^{\circ}$ (Dalton et al., 2014). Increasing the mantle potential temperature by $200^{\circ} \mathrm{C}$, as may be appropriate for the Hadean or Archean Earth (Sleep and Windley, 1982; Bickle, 1986; Abbott et al., 1994; Herzberg et al., 2010), increases the predicted crustal thickness to $25 \mathrm{~km}$ (Figure 6). Such a thick crust would be quite buoyant and difficult to subduct, potentially explaining the difference of geodynamic regime between the Archean and the present (Korenaga, 2006; Korenaga and Korenaga, 2008). In particular, it may be impossible to maintain a plate-tectonics regime on a hotter Earth, with thick oceanic crust: The planet may enter a stagnant-lid mantle convection mode (Sleep, 2000, and see Section 5.2). But even on present-day Earth the uppermantle temperature underneath the MOR system varies significantly. On the one hand, high temperatures approaching $1500^{\circ} \mathrm{C}$ have been deduced underneath certain locations along the MOR system, especially at the hotspots of Saint Paul/Amsterdam and Iceland (Dalton et al., 2014), where indeed the oceanic crust is several kilometres thicker that the reference value of $7 \mathrm{~km}$. On the other hand, an anomalously cold mantle generating thin crust may explain the anomalously deep seafloor of the Antarctica-Australia Discordance (Klein et al., 1991; Holmes et al., 2008).

\subsection{Preparing the plate: Near-axis modification}

Melting leaves behind a solid residuum that is compositionally different from the original mantle (Workman and Hart, 2005; Warren, 2016). This depletion will be important for the more mature oceanic plate as it provides an initial stratification that does not depend on age. There are several aspects to this depletion. First, as we have seen, the residuum is olivine-rich 
compared to "standard" mantle. This makes it harder to melt and perhaps slightly more viscous than regular mantle (Farla et al., 2013; Hansen and Warren, 2015). In addition, volatiles, such as water and carbon dioxide, are preferentially incorporated into the melt. Even though the volatile content of Depleted MORB-source Mantle (DMM) is low (Hirth and Kohlstedt, 1996; Warren and Hauri, 2014), there are clear chemical traces of a small amount of melting under hydrous condition in MOR basalts (Asimow and Langmuir, 2003). The amount of such hydrous melt is limited by the associated drying of the mantle upon melting. Even though this melt is not volumetrically dominant at MORs over dry melting, it causes the resulting mantle to become progressively dried between 100 and $60 \mathrm{~km}$ depth. Such a dry, 80-km thick lithosphere has, for example, been detected near the axis of the East Pacific Rise (Evans et al., 2005) and at the NoMelt-experiment site in the central Pacific Ocean (Sarafian et al., 2015).

Carbon dioxide is also likely to induce melting at even greater depth, around $200 \mathrm{~km}$ (Dasgupta et al., 2013). This carbonatite melt produced at such depth is very low-volume (Dasgupta and Hirschmann, 2006) and should have a strong effect on mantle properties only if its dihedral angle is close to zero (Dasgupta et al., 2013; Yoshino et al., 2009). Even though carbonatite melt facilitates the development of melt extraction channels (Keller and Katz, 2016), most of it is likely present far enough from the axis that it will not be extracted at the MOR.

If melt does rise to the level of a shallow permeability barrier, the crystallisation products locally modify the composition of the lithosphere. Crystallisation products have been identified in oceanic and ophiolitic peridotites, whether in the form of pyroxenite veins (Dantas et al., 2007; Warren, 2016) or more diffuse refertilisation (Johnson and Dick, 1992; Hellebrand et al., 2002; Le Roux et al., 2007; Müntener et al., 2009). Therefore, the oceanic lithosphere is not simply the residual of melting, but has been metasomatised by the time it exits the MOR system. Metasomatised lithosphere has, as an example, been called for to explain the origin of the mantle reservoir dubbed EM2 (Workman et al., 2004). In addition, Lizarralde et al. (2004) found that the seismic velocity of the top $30 \mathrm{~km}$ of the oceanic lithosphere far off the ridge axis is consistent with gabbro being mixed with mantle peridotite. The amount of gabbro is apparently higher where the lithosphere was formed at a slow spreading centre than at a fast spreading centre. It can be equivalent to $1.5 \mathrm{~km}$ of crustal material spread over approximately $30 \mathrm{~km}$.

As water is an incompatible element, refertilisation by melt crystallisation 
does not increase the water content of the lithosphere until crystallisation is nearly complete. By contrast, hydrothermal circulation has the potential of hydrating the lithosphere; whether it can reach significant depths at a MOR remains a matter of debate. Seawater circulates in the upper reaches of the oceanic crust in convection cells driven by on-axis magmatic activity (e.g., Alt, 1995; German and Lin, 2004) and has important implications: Fluidrock interaction generates valuable mineral deposits (Tivey, 2007), modifies the chemistry of the oceans (Von Damm et al., 1985; Kump, 2008; German et al., 2016), and changes the thermal state of the growing oceanic plate (Sleep, 1975; Morgan and Chen, 1993; Cherkaoui et al., 2003; Iyer et al., 2010; Roland et al., 2010). If hydrothermal circulation were not included in the results of Figure 6, the predicted crust would be one or two kilometres thicker.

Most studies of hydrothermal circulation at MORs have focused on the near-axis environment (e.g., Theissen-Krah et al., 2016), where it is most intense and carries most heat. Circulation there is limited to depths shallower than magma chambers, and therefore has a limited effect on the composition of the lithosphere. However, there is chemical and geological evidence of near-axis hydrothermal circulation throughout the crust (McCollom and Shock, 1998; Bosch et al., 2004; Gillis et al., 2005; Hasenclever et al., 2014; Harris et al., 2017) and shallow circulation over older lithosphere (Fisher et al., 2003; Fisher and Von Herzen, 2005). Hydrothermal circulation requires relatively high permeability rocks. Where the crust is sedimented, this requires passageways, often provided by seamounts or basement highs, through the low-permeability sediment layer (Hutnak et al., 2006; Winslow and Fisher, 2015). Likewise, to reach the bottom of the crust, sufficient permeability is required. Nicolas et al. (2003) argue that a network of microcracks parallel to the ridge plane enables fluid circulation to the lower crust. However, deep hydrothermal circulation is not present in every MOR (Faak and Gillis, 2016) and what controls its occurrence is not yet well understood.

If fracturing is key to enable hydrothermal circulation, active faulting, detected both by structural analysis and by seismic activity, may be associated with the presence of fluids. At slow spreading centres, long-lived detachment at the axis can reach the middle crust and provide fluid pathways (Tucholke et al., 1998; deMartin et al., 2007; Cannat et al., 2009). Serpentine produced by interaction between mafic rocks has been recovered from the detachment surface (Karson et al., 2006). At ultraslow spreading centres, microearthquakes can reach into the mantle (Schmid and Schlindwein, 2016), 
and hydrothermal activity is surprisingly high (Edmonds et al., 2003; Pedersen et al., 2010). Serpentinisation is exothermic and the heat release may drive hydrothermal circulation at ultraslow spreading centres (Baker et al., 2004; Cannat et al., 2010), as in the famous "Lost City" vent site (Kelley et al., 2001). Most earthquakes in other locations are related to transform faults. Therefore, transform faults may serve as conduits of fluids into the lithosphere. Seismic moment release implies that an aseismic material, likely serpentine, coats much of the fault surface (Boettcher and Jordan, 2004). As earthquakes at transform faults can reach several tens of kilometres depth, it is likely that fluid can penetrate well into the mantle.

The consequence of hydrothermal circulation is that the young oceanic plate is probably hydrated at least to the depth of magma chambers at fast spreading centres, and likely throughout the crust at slow to ultraslow spreading centres. The mantle can also be hydrated, but this hydration is likely restricted to transform faults.

\subsection{Spreading-ridge inheritance}

While on the continents, rifts typically retain at least a fraction of the original lithosphere, extension at MORs has proceeded to the extent that all preexisting lithosphere is now far from the ridge. The oceanic lithosphere created at MORs is a blank slate on which the thermal, mechanical, and chemical processes described in the previous section leave their imprint until the plate is recycled at a subduction zone.

Or is it? While extension stretches the lithosphere to its breaking point and crust is formed by melting of the mantle underneath the ridge, traces of preexisting lithosphere have been found. First, the segmentation of the ridge axis can often be followed to the rifted margin. Second, there is mounting evidence for continental crust or lithospheric materials involved in a MOR (as we describe in detail below).

Young spreading centres like the Red Sea, the Gulf of Aden, or the Gulf of California clearly follow the shape of surrounding continental margins (Leroy et al., 2010), whether this segmentation is the result of preexisting zones of weakness in the continent (Taylor et al., 2009; Bellahsen et al., 2013) or deeper thermal or compositional heterogeneities in the nascent spreading centre (Bonatti, 1985; Lizarralde et al., 2007; D'Acremont et al., 2010; Almalki et al., 2016). Transform fault initiation has been modelled in analogue (Oldenburg and Brune, 1972; Katz et al., 2005) and in numerical experiments (Hieronymus, 2004; Choi et al., 2008; Gerya, 2010, 2012; Püthe and Gerya, 
2014). In these models, transform faults appear as rotated ridge segments sheared by along-strike variations in spreading-centre asymmetry accompanied by weakening of the sheared lithosphere. While, locally, there is evidence of segmentation linked to spreading asymmetry (Gernigon et al., 2015), it has been ruled out in other locations (Parson et al., 1990) and it remains to be seen if this view of segmentation is compatible with the limited spreading asymmetry observed globally (Müller et al., 2008, see Figure 3). The circumstances under which segmentation is controlled by this dynamic instability or by preexisting conditions also remain to be determined.

What is clear is that, at least in some cases, segmentation can be stable over very long duration. For example, the St. Paul and Romanche fracture zones in the Atlantic Ocean can be followed all the way to prominent offsets in the coasts of Western Africa and South America (e.g., Müller and Roest, 1992). Smaller offsets can be perturbed by ridge jumps or changes in plate motions (Scemundsson, 1974; Wilson et al., 1984; Wilson and Hey, 1995; Hardarson et al., 1997; Müller et al., 2001), but even so, they can be preserved for tens of millions of years (Briais and Rabinowicz, 2002). The sinuosity of the Gakkel ridge, for example, follows closely the shape of the Siberian margin and the conjugate Lomonosov Ridge, $40 \mathrm{Myr}$ after spreading started (Vogt et al., 1979; Michael et al., 2003).

How well segmentation is preserved in the long-term likely depends on strength heterogeneities in the lithosphere. Transform faults are both weak when sheared (Morgan and Parmentier, 1984; Behn et al., 2002) and, as the lithosphere is thicker at the transform boundary than in the adjacent ridge (Morgan and Forsyth, 1988; Shen and Forsyth, 1992; Roland et al., 2010), strong when compressed. Also, as the lithosphere is thinner at the ridge axis than in the older plate, stress is focused to the ridge axis. In addition, the lithospheric thickness gradient generates a ridge "push" that further drives extension at the preexisting axis (Forsyth and Uyeda, 1975).

Materials older than the ocean basin have occasionally been identified in the MOR system, showing that the ridge has not completely reset the preexisting lithosphere. Bonatti et al. (1996) documented sediments in the Romanche transform fault zone that are $20 \mathrm{Myr}$ older than the opening of the Atlantic Ocean. In this case, it is possible that the extreme length of the transform boundary produces a lithosphere that is so thick that faults avoid propagating into this region. Instead, they curve and cut a lens-shaped region in the transform domain that is unaffected by MOR processes (Ligi et al., 2002). Such lenses may be present at the Romanche transform (900- 
km long) and at the Andrew Bain transform (750-km long) at the Southwest Indian Ridge, and their width can exceed $100 \mathrm{~km}$ (Ligi et al., 2002).

Even older or continental material is increasingly being recognised at

MORs. Torsvik et al. (2015) argued that the elevated ${ }^{87} \mathrm{Sr} /{ }^{86} \mathrm{Sr}$ and ${ }^{207} \mathrm{~Pb} /{ }^{204} \mathrm{~Pb}$ of Öræfajökull (Iceland) lava are evidence for assimilation of crustal crust by the rising MOR and plume produced melt. In this case, a continental fragment may have been separated from the Jan Mayen Microcontinent by a ridge jump. Proterozoic and Archean zircons recovered at Mauritius are also evidence for a continental fragment, in this case related to Madagascar, involved in recent MOR and plume activities (Torsvik et al., 2013; Ashwal et al., 2017). Both locations are characterised by plume-ridge interaction and accompanying ridge jumps. It is possible that some rifts are not stable for enough time to completely dissociate trapped continental fragment. Possible evidence for subcontinental lithosphere at the Lena trough has recently been refuted (Lassiter et al., 2014). Therefore, ancient mantle involved in MORs appears to be linked to heterogeneity in the upwelling mantle (Liu et al., 2008) or to ridge jumps (Torsvik et al., 2015).

\section{Ocean-Plate Cooling}

Convection in the Earth's mantle, which drives the motions of the Earth's tectonic plates, occurs because it efficiently transports heat out of the mantle interior (e.g., Turcotte and Oxburgh, 1967). Indeed, most of Earth's heat loss ( $\sim 32$ TW out of a total of $\sim 46$ TW) occurs within the ocean basins (e.g., Jaupart et al., 2015) as the oceanic lithosphere cools and contracts moving away from the mid-ocean ridges. Most of the heat loss through the oceanic lithosphere happens on the flanks of the mid-ocean ridges: For example, $75 \%$ of oceanic heat flow arises from the $60 \%$ of seafloor that is younger than 66.5 Ma (Cenozoic ages; Davies and Davies, 2010). Not only does younger seafloor transfer more heat per unit area than older seafloor (e.g., Parsons and Sclater, 1977), but it also is more abundant in the ocean basins because it is less likely to have been already subducted (e.g., Rowley, 2002). However, the fraction of the seafloor covered by the ridge flanks depends on ridge length and plate speeds, both of which have changed with time as the tectonic configuration of ocean plates has evolved (Becker et al., 2009; Coltice et al., 2012). As a result, the total oceanic heat flow during the Mesozoic and Cenozoic also changes with time (Loyd et al., 2007), which probably leads to mantle temperature changes. Here, we examine how oceanic heat 
flow and other seafloor characteristics are affected by ocean basin tectonics during their lifetime, moving from their birth at mid-ocean ridges to their death at trenches.

\subsection{Heat flow and subsidence of the oceanic plates}

The volcanism of the mid-ocean ridges directly exposes hot mantle rocks to cold seawater. As the ocean plates move away from ridge axes at a few $\mathrm{cm} / \mathrm{yr}$, the plates conduct heat from the mantle interior into the surface environment. This loss of heat from the uppermost mantle has two important consequences. First, the cooling stiffens the rocks of the lithosphere (Kohlstedt et al., 1995), which causes the tectonic plates to behave both rigidly and elastically. Second, as the lithosphere thickens and cools moving away from the ridge, the rocks of the lithosphere thermally contract, producing a net seafloor subsidence of several kilometres between the mid-ocean ridge crest and the abyssal plains. The resulting relationship between heat flow, seafloor depth, and seafloor age moving away from the mid-ocean ridges has become a classic problem in Geodynamics (e.g., Parsons and Sclater, 1977), the details of which are still being debated (e.g., Korenaga and Korenaga, 2016).

For seafloor younger than about $70 \mathrm{Ma}$, the depth of the seafloor depends linearly on the square root of seafloor age (Korenaga and Korenaga, 2008), as expected based on the solution to cooling of a semi-infinite halfspace (e.g., Davis and Lister, 1974). However, the slope of this relationship (rate of subsidence) depends on several parameters including mantle temperature, thermal expansivity, and thermal conductivity, all of which are at least somewhat uncertain for the upper mantle and may vary spatially (Marty and Cazenave, 1989) or with plate age (Korenaga and Korenaga, 2008, 2016; Hasterok, 2013; Adam et al., 2015). Mantle temperature, in particular, has been shown to vary along the ridge axis (Dalton et al., 2014), which should lead to variations in subsidence rate away from the ridge. Given this complexity, the rate of seafloor subsidence is usually constrained empirically from bathymetric observations (Parsons and Sclater, 1977; Stein and Stein, 1992; Crosby and McKenzie, 2009), especially after accounting for topographic variations associated with sedimentation and volcanism (Korenaga and Korenaga, 2008). However, different analysis methods, as well as other poorly constrained contributions to topography, such as crustal thickness (Winterbourne et al., 2014) or dynamic topography (Adam et al., 2015; Hoggard et al., 2016; Watkins and Conrad, 2018) variations, have led to a range of proposed seafloor subsidence rates, varying between $\sim 320 \mathrm{~m} / \mathrm{Myr}^{1 / 2}$ (Korenaga and 
Korenaga, 2008; Crosby and McKenzie, 2009) and $415 \mathrm{~m} / \mathrm{Myr}^{1 / 2}$ (Hasterok, 2013). Regional analyses of specific ridge flanks show an even wider range of variability (e.g., Marty and Cazenave, 1989; Hillier and Watts, 2005; Watkins and Conrad, 2018). The different proposed subsidence curves approximately follow the lower envelope of seafloor depth observations (Figure 7a) because bathymetry is preferentially shallowed by the accumulation of sediments and volcanic debris. These different subsidence curves are associated with different lithospheric cooling models that correspond to a range of possible rates of heat transfer across the oceanic plate (e.g., Figure 7b).

Seafloor older than about 70 Ma continues to subside, although at rates significantly slower than those that apply closer to the ridge. Indeed, the wide variability among the proposed subsidence curves for seafloor ages greater than $\sim 100 \mathrm{Ma}$ (Figure 7a) partly reflects the challenge of assigning average behaviour to older seafloor, which is significantly less prevalent in the ocean basins, and generally more obscured by volcanism and sediments, compared to younger seafloor. The "flattening" of the seafloor depth curves beyond $\sim 70$ Ma (Colin and Fleitout, 1990) may reflect deviations from halfspace cooling induced by the introduction of additional heat to the lithospheric base once the lithosphere reaches a thickness of about $\sim 100 \mathrm{~km}$ (e.g., Stein and Stein, 1992). This added heat prevents the plate from thickening further, and may result from small-scale convection beneath the plate that initiates once the lithosphere becomes convectively unstable (e.g., Davaille and Jaupart, 1994; Huang et al., 2003; Doin and Fleitout, 1996, 2000; Hillier, 2010). Because this additional heat is eventually conducted through the plate, thermal models that include a maximum plate thickness (e.g., Stein and Stein, 1992; Hasterok, 2013) also predict higher heat flow for older seafloor ages compared to those that allow plates to grow thicker (e.g., Parsons and Sclater, 1977, Figure 7b). On the other hand, Korenaga and Korenaga (2008) noted that the littering of older seafloor by volcanic debris makes it difficult to statistically confirm seafloor flattening, and instead proposed a more gradual subsidence across all seafloor ages, which significantly deepens the oldest seafloor (Figure 7a).

Although the different thermal models of oceanic lithosphere predict varying patterns of seafloor subsidence (Figure 7a), differences between the heatflow curves predicted by these models are relatively smaller (Figure 7b). Indeed, the largest differences are for the oldest lithosphere, which covers only a relatively small portion of seafloor. Therefore, the total heat flow predicted by these models is relatively well-constrained, and indeed Jaupart 
et al. (2015) considered these uncertainties and estimated a total oceanic heat flow (excluding contributions from hotspots) of $\sim 29 \mathrm{TW}$, with a few TW of uncertainty. This range is consistent with the convolution of the heat-flow curves (Figure 7b) with the present-day seafloor age map (Figure 8a), for which we find a range of total seafloor heat flow between 26.5 TW (Parsons and Sclater, 1977), 29 TW (e.g., Stein and Stein, 1992; Hasterok, 2013) and 31 TW (Korenaga and Korenaga, 2008). The older thermal model (Parsons and Sclater, 1977) predicts smaller heat flow (for all ages; Figure 7b) because that model assumes cooler mantle temperatures and smaller thermal conductivity. The Korenaga and Korenaga (2008) model predicts higher heat flow along the ridge flanks compared to other models (Figure 7b) and therefore predicts higher total heat flow. Jaupart et al. (2015) estimate that hotspots add another $2-4 \mathrm{TW}$ of heat flow, and suggest that the present-day seafloor is cooling the mantle at a rate of $32 \pm 2 \mathrm{TW}$.

\subsection{Basin evolution over geologic time}

Because oceanic heat flow is so dependent on seafloor age (Figure 7b), total oceanic heat flow is considerably dependent on the tectonic configuration of the seafloor, which has changed with time. Fortunately, tectonic reconstructions developed during the past decade have included models for past seafloor ages (Xu et al., 2006; Müller et al., 2008, 2016; Seton et al., 2012), which enables us to estimate oceanic heat flow for past times (e.g., Loyd et al., 2007). For this, we have computed the area-age distribution of the seafloor (Figure 8, right column) for the seafloor reconstructions of Müller et al. (2016) for the Mesozoic and Cenozoic (Figure 8, left column). These reconstructions exhibit significant variations during this timeframe as the Atlantic basin grows at the expense of the Pacific. Most importantly, the Pacific basin transitions from having three primary ridges at $200 \mathrm{Ma}$ (Figure 8g), to a central (Pacific) plate surrounded by several other ridges during the Cretaceous (Figure 8e and c), and then to a single dominant ridge system today (Figure 8a) as many of the peripheral ridges are lost to subduction. These trends cause the area of the ridge flanks (seafloor younger than $\sim 60 \mathrm{Ma}$ ) to first increase during the Cretaceous, and then decrease during the Cenozoic toward the present (Figure 8, right column). The proportion of oldest lithosphere (seafloor older than $\sim 120 \mathrm{Ma}$ ) conversely decreased during the Cretaceous, and increased afterwards. Indeed, the present-day seafloor (Figure 8a and b) has less ridge-flank area and more elderly lithosphere than at any point in the previous 200 Myr (Figure 8). 
Tectonic changes of Earth's seafloor (Figure 8) can lead to significant geologic changes on Earth's surface. For example, the younger average age of the seafloor during the second half of the Cretaceous (Figure 8) should have produced an on-average shallower seafloor, and higher sea level, during that time. We estimated the sea level changes associated with the tectonic evolution of the seafloor by convolving the seafloor age-depth curves (Figure 7a) with the area-age distributions for past times (Figure 8), assuming constant water volume and isostatic compensation. This calculation predicts, similar to previous studies (e.g., Kominz, 1984; Xu et al., 2006; Müller et al., 2008; Conrad, 2013; Dutkiewicz et al., 2017), that sea level during the mid-Cretaceous was several hundred meters higher than it is today (Figure $9 a)$. Despite the $\sim 100 \mathrm{~m}$ uncertainty associated with the choice of a seafloor age-depth relationship (Figure 9a), this prediction largely explains global continental transgressions (e.g., Torsvik and Cocks, 2016b) that have been stratigraphically constrained to represent a sea level highstand of up to $\sim 250$ $\mathrm{m}$ during the Cretaceous (Haq, 2014). Indeed, tectonic changes to Earth's ridge system are thought to be the primary driver of Phanerozoic sea-level change, producing fluctuations of hundreds of meters occurring on timescales of hundreds of millions of years (Müller et al., 2008; Conrad, 2013).

Because most of Earth's heat loss occurs through the seafloor, tectonic changes in the ocean plates can drive thermal changes in Earth's convecting mantle. Applying the heat-flow vs. seafloor-age curves (Figure $7 \mathrm{~b}$ ) to the past seafloor (Figure 8), we compute changes in total oceanic heat flow as a function of time (Figure 9b). The different heat-flow vs. seafloor-age curves all yield a similar history, and differ from each other by at most $10 \%$ (up to $\pm 4 \mathrm{TW}$ ). Tests using alternative tectonic models (e.g., Seton et al., 2012) similarly indicate $\sim 10 \%$ uncertainty in magnitude, but not in Cenozoic and Mesozoic trends. In each case, we find that the highest heat flow coincides with the sea level highstand during the mid to late Cretaceous, when the ridge-flank area was greatest (Figure 8c-f) and the smallest heat flow occurs at $200 \mathrm{Ma}$ and today. Indeed, during the mid-Cretaceous, the oceanic heat flow was about $30-40 \%$ larger than it is today (maximum of $\sim 40 \mathrm{TW}$ at 120 Ma, compared to $\sim 30 \mathrm{TW}$ today, Figure $9 \mathrm{~b}$ ), and for much of the Cretaceous, the oceanic heat flow was $\sim 20 \%$ larger than today. Nearly all of this increase is associated with tectonic changes in the Pacific basin, because contributions from the Atlantic and Indian basins are changing only monotonically during this time period (Figure 9b).

Such large variations in heat flow are the natural result of variations in 
the tectonic configuration of the seafloor, and they should result in changes in the temperature of the convecting mantle. Assuming a heat capacity of $1250 \mathrm{~J} \mathrm{~kg}^{-1} \mathrm{~K}^{-1}$ (Jaupart et al., 2015) and an upper mantle mass of $10^{24} \mathrm{~kg}$, we estimate that a $25 \%$ increase in average heat flow above $31 \mathrm{TW}$ that is sustained for $40 \mathrm{Myr}$ should cool the upper mantle by an extra $8^{\circ} \mathrm{C}$ compared to the 31 TW of background cooling. This temperature change may be amplified if it is regionally confined (e.g., within the Pacific basin), and could slow down upper-mantle dynamics if upper mantle rocks become sufficiently stiffened. Such a negative feedback mechanism may limit the lifetime of any period of accelerated heat flow from the tectonic plates, and may be linked to cyclicity associated with supercontinental cycles (Grigné et al., 2005). On the other hand, the mid-Cretaceous was a period of intense Pacific volcanism (Coffin and Eldholm, 2005), which suggests that the amplified heat flow may reflect a tectonic response to a period of elevated mantle temperatures beneath the Pacific basin (Ricciardi and Abbott, 1996). Regardless of whether these temporal changes are driven by seafloor tectonics or mantle dynamics, it is clear that oceanic heat flow may be elevated by at least $25 \%$ during extended periods of several tens of millions of years.

\subsection{Preparation for subduction}

Eventually, all oceanic plates subduct into the mantle, and bring with them the lithospheric thermal structures and surface debris (volcanics and sediments) that they accumulated during their lifetimes. The structures that oceanic plates bring to the subduction zone therefore depend on their tectonic history, which has changed with time as the ocean basins have evolved. To characterise such changes, we have computed rates of subduction, and ages of subducting material, as a function of time since the Mesozoic from the tectonic model of Müller et al. (2016) (Figure 9c). We find that the peak rate of subduction occurred just before the peak in global heat flow $(\sim 150-120$ Ma) (Figure 9c) and involved subduction of a large fraction of seafloor that is older than 80 Myr. Since the late Cretaceous, much younger seafloor has been subducting, with at least one third of subducting seafloor being younger than 40 Myr for much of the Cenozoic (Figure 9c).

Constraints on the relative areas of old and young lithosphere being subducted (Figure 9c) suggest that the Jurassic and early Cretaceous (that is, times before $\sim 120 \mathrm{Ma}$ ) featured ample subduction of old lithosphere and relatively little subduction of young lithosphere. By contrast, the Cenozoic featured subduction of a greater fraction of young lithosphere, which should 
decrease plate-driving forces like slab pull, and perhaps helps to explain the slowdown of global spreading rates since $120 \mathrm{Ma}$ (Figure 9c). Because subduction of old lithosphere also transports more water (e.g., van Keken et al., 2011) and possibly more carbon (Dasgupta and Hirschmann, 2010; Thomson et al., 2016; Clift, 2017) into the deep mantle compared to younger lithosphere, we also expect that the mantle accumulated more of these volatiles before the mid-Cretaceous than it has during the Cenozoic. This modulation of volatile cycling by ocean-basin tectonics should have important consequences for long-term changes in Earth's climate (van der Meer et al., 2014), sea level (Conrad, 2013), and deep mantle dynamics (Crowley et al., 2011; Korenaga, 2011; Sandu et al., 2011).

\section{Ocean-Plate Destruction}

Based on current seafloor age distribution, oceanic plates do not grow older than about 200 Million years (see Section 3.2). The age of the oldest oceanic-plate portions remaining at the surface, however, varies through time and has been less during Earth's most recent history (Figure 8). The destructive process limiting their age is subduction, the surface-plate immersion into the deep planetary interior. Upon arriving at the subduction trench, the thermally contracted plate is at its coldest, thickest and heaviest state (as discussed in Section 3.3). The resulting large buoyancy contrast with its surrounding mantle turns the subducting plate into the dominant dynamic driver of global deformation on our planet (Forsyth and Uyeda, 1975; Davies, 1981; Conrad and Lithgow-Bertelloni, 2002), clearly exceeding contributions from the bottom boundary layer that feed active mantle upwellings (Zhong, 2006), and therefore confining the latter's importance to regional scales (Lithgow-Bertelloni and Silver, 1998; Cande and Stegman, 2011; Becker and Faccenna, 2011) or supportive roles on global scale (Steiner and Conrad, 2007; Faccenna et al., 2013). Subduction of an oceanic plate, slowly evolving over Millions of years, is strongly controlled by deformation mechanisms acting on the tiny spatial scale of crystals and over the fleetingly short temporal scale of earthquakes. Subduction zones are exceptionally diverse, with large variations present between individual subduction zones, and even along lateral portions of individual subducting plates. Indeed, subduction, the fate of an oceanic plate, is intriguingly complex.

Oceanic plates find their way back into the mantle at convergent margins, which span in total around $42000 \mathrm{~km}$ on present-day Earth. Along around 
$40 \%$ of this total length, oceanic plates subduct below other oceanic plates (Leat and Larter, 2003). Along the remaining around $60 \%$ of total trench length, oceanic plates subduct below a lighter, thicker continental plate. A subduction zone is often conceptualised in a vertical, two-dimensional crosssection: A purely trench-perpendicular moving oceanic plate with one given plate age at the trench, one given thickness, one given composition sinks in the mantle with one given polarity and one given dip angle, and it might or might not penetrate directly into the lower mantle. A subduction zone is, however, one of the characteristically three-dimensional large-scale features of the Earth (see e.g., Jadamec, 2016, and references therein). The clear and distinct 3-D structure of the oceanic plate is most-easily observed at the surface, where most subduction trenches are arcuate (e.g., Sdrolias and Müller, 2006).

\subsection{Necessities for subduction}

\subsubsection{Why the plate sinks}

The basaltic rocks making up the upper-most part of the oceanic plate are its lightest part; in fact, even lighter than the hot asthenosphere just underneath the plate. The plate acts, however, as an integral system comprising the light basaltic rocks (i.e., the crust) together with the significantly heavier sub-crustal rocks of the shallow, rigid part of the mantle. Together they form the mechanically cohesive lithosphere, which can become, as a whole, denser than the underlying mantle rocks: Eventually, the cold oceanic plate becomes gravitationally unstable and wants to sink on its own. During the sinking, the cold oceanic plate becomes even denser due to the pressure increase and the compressibility of its rocks and transformation of the crust to eclogite. The oceanic plate remains therefore heavier than the surrounding mantle as long as it is colder; it sinks and sinks.

\subsubsection{Will the plate sink?}

Subduction should be occurring everywhere, given that the cooling oceanic plate becomes quickly (at a plate age of around $20 \mathrm{Myr}$ ) heavier than the underlying mantle (e.g., Davies, 1992). Yet, we have discovered only one single rocky planetary body (Earth) with viable, plate-driving subduction amongst many others at the present day. Even Venus, similar to Earth in many respects, does not have active, plate-shifting tectonics even though it shows signs of short, subducted plate portions (Sandwell and Schubert, 1992; 
Schubert and Sandwell, 1995; Davaille et al., 2017). Also, numerical models applying the rheologic laws suitable for the mantle preferentially yield a stagnant, mostly rigid lid - that does not subduct - above a separately convecting mantle (Nataf and Richter, 1982; Stengel et al., 1982; Moresi and Solomatov, 1995; Solomatov, 1995; Ratcliff et al., 1997). All these reasons suggest that the development of a mobile lid seems indeed to be the special, rather than the normal, case for an Earth-sized, rocky planetary body.

Understanding under what conditions the surface plate becomes mobile (or, in reverse, stagnant) is still not entirely clear. It is, however, clear that starting (or stopping) mobile plate tectonics is strongly linked to the onset (or shut down) of subduction (e.g., Gerya, 2011; van Hunen and Moyen, 2012). One of the most elusive parts of starting subduction is the necessity to initially break it. Many mechanisms have been proposed to facilitate breaking an intact surface plate and subsequent subduction initiation. They all cause, at least, either an additional forcing to the plate, a localisation of the existing forcing, or a weakening of the plate:

- Meteorite impact (Hansen, 2007)

- Sediment loading (Regenauer-Lieb et al., 2001; Nikolaeva et al., 2010)

- Major episode of delamination (Toth and Gurnis, 1998)

- Small-scale convection in the sub-lithospheric mantle (Solomatov, 2004)

- Interaction of thermo-chemical plumes with the lithosphere (Ueda et al., 2008; Burov and Cloetingh, 2010; Burov and Gerya, 2014; Gerya et al., 2015; Crameri and Tackley, 2016; Davaille et al., 2017)

- Plate bending via surface topography variations (Crameri and Tackley, 2016)

- Elasticity of the plate (Toth and Gurnis, 1998; Regenauer-Lieb et al., 2001; Hall et al., 2003; Thielmann and Kaus, 2012)

- Preexisting transform fault (Gurnis et al., 1998; Hall et al., 2003; Nikolaeva et al., 2010)

- Preexisting oceanic plateau (Niu et al., 2003; Nair and Chacko, 2008) 
- Addition of water or melt into the lithosphere (Hirth and Kohlstedt, 2003; Dymkova and Gerya, 2013)

- Grain-size reduction (e.g., Karato et al., 1980, 1986; Bercovici and Ricard, 2005; Rozel et al., 2011; Bercovici and Ricard, 2013, 2014)

- Void generation (Bercovici, 1998; Regenauer-Lieb, 1998)

- Shear-heating (Yuen et al., 1978; Crameri and Kaus, 2010; Thielmann and Kaus, 2012; Lu et al., 2015)

Of the many candidates, none seems to be capable of causing subduction initiation on its own. On the contrary, it seems likely that some sort of combination of the above mechanisms is needed to initiate subduction. It is also worth noting that subduction initiation from a fully intact initial plate might, however, not necessarily have happened on Earth: The sinking surface plates might have evolved continuously from the pre-existing overturn of an initial, shallow magma ocean (as further discussed in Section 5.2). Subduction initiation also becomes less enigmatic once multiple discrete plates have formed. The additional tectonic forces arising from the pull of multiple subduction zones and the presence of continental lithosphere seem to facilitate initiation of new subduction zones (e.g., Rolf and Tackley, 2011). The geologic record therefore hints at multiple initiations during recent geologic times. Most of them have occurred in the intra-oceanic setting of the Pacific basin during the Cenozoic (Gurnis et al., 2004; Arculus et al., 2015). New subduction zones also form by splitting from existing ones either by subduction polarity reversals, as is suggested for the South Sandwich subduction zone (Crameri and Tackley, 2014), or by simple splitting due to lithospheric heterogeneities (e.g., Duarte et al., 2016). In any case this might lead to 'infection' of an intact, neighbouring ocean basin (Waldron et al., 2014; Duarte et al., 2016).

Once the plate is broken apart, one necessity that makes subsequent subduction so apparently difficult is that the oceanic plate has to be both weak and strong at the same time: It has to be weak on the outside (i.e., its outermost parts) to enable the necessary bending at the trench, and strong on the inside (i.e., in its core) to still be able to transfer the slab pull to the trailing surface plate (see e.g., Figure 10). The bending of the plate is facilitated by both its free surface and its weak uppermost crustal layer. The plate surface can deform freely as it is covered only by low-density, lowviscosity water and/or air (Figure 10a). While the free plate surface enables 
a gentler bending by creating a bulge in front of the subduction zone and a deep trench, the weak, brittle nature of the crust is the key part to enable a relatively strong plate bending to a typical bending radius of around 200-400 km (Wu et al., 2008; Buffett and Heuret, 2011). The strong, non-brittle plate core resists bending (Buffett, 2006), but is, on the other hand, the integral part that enables transferring the enormous stresses arising at depth to the surface.

For subduction to occur and be maintained, the net plate driving force must be positive (see Turcotte and Schubert, 2014; Gerya, 2011, and references therein). A net driving force originates from a negative slab-mantle buoyancy contrast (causing slab pull and suction), and the positive ridge topography (causing ridge push). Resistance arises from the deformation work needed for the plate to sink: The oceanic plate is coupled to some degree with the adjacent, colliding upper-plate and the surrounding mantle at depth. Compared to observations on Earth, the depth of the back-arc basin is generally overestimated in numerical models like the one shown in Figure 10 due to overly strong slab suction at the base of the upper plate. Apart from the lubricating crustal layer itself (Lenardic and Kaula, 1994), a lowviscosity mantle wedge caused by dehydration of pulled-down wet sediments is a crucial ingredient to reduce the plate-plate and plate-mantle couplings significantly (e.g., Billen and Gurnis, 2001) and therefore leads to a more shallow back-arc basin (Crameri et al., 2017). Additional resistance to subduction arises due to the fact that some of the slab pull is consumed for plate bending (Buffett, 2006), even though numerical models indicate that the major part of viscous dissipation occurs via shearing in the subduction fault rather than bending (Conrad and Hager, 1999; Crameri et al., 2017).

\subsection{Sinking-plate characteristics}

The actual amount and distribution of forces on the subducting oceanic plate and its structural composition is highly variable in space and time; and so is the way the plate sinks. Based on surface-plate velocities and the dominant seismic activity of the plate interface, it has become clear that the sinking of oceanic plates is always single-sided; only one plate sinks at a time, while the opposite plate remains at the surface. Its single-sidedness is probably the most defining characteristic of a subduction system and it has puzzled

scientists for many decades. In fact, answering the question of why only one plate sinks at a time has been one of the major long-standing open questions of Earth Sciences and when put into words, "one of the greater mysteries in 
geodynamics" (Bercovici et al., 2000) until only recently. During that time, various agents have been proposed to cause the intriguing single-sidedness at subduction zones. Chemically light continents were the most often suggested candidates (e.g., Lenardic and Kaula, 1996), even though it is obvious that ocean-ocean convergent boundaries are typically single-sided too. Others suggested that double-sided plate sinking would be interrupted when, during subduction, one plate has to bend significantly more than $90^{\circ}$ due to variations in surrounding mantle flow (Turcotte and Schubert, 2014). However, dynamically self-consistent global models of mantle convection clearly showed that double-sided subduction is dominant even during phases of increased subduction asymmetry (e.g., Tackley, 2000). A major insight was then given by regional modelling: Gerya et al. (2008) came to the conclusion that high plate strength and the presence of water (with its plate-interface weakening effect) on Earth are major factors controlling a self-sustaining, single-sided subduction processes.

The breakthrough came, however, finally from the combination of a weak plate interface and a free surface. On their own, the two physical complexities were no unknowns: The important effects of the weak plate interface (Gurnis and Hager, 1988; King and Hager, 1990; Zhong and Gurnis, 1995; Lenardic and Kaula, 1994; Moresi and Solomatov, 1998; Tagawa et al., 2007; Gerya et al., 2008) and the free surface (Gurnis et al., 1996; Schmeling et al., 2008; Kaus et al., 2010) had been pointed out already. However, it was their combination that turned out to be the key for a subduction zone's characteristic (self-consistent) single-sidedness (Crameri et al., 2012), with a weak, hydrated crustal layer preventing strong coupling between upper- and lower plate and the free surface relieving some of the plate bending stresses and ensuring an intact, strong plate core (see e.g., Figure 10). Other important factors to support temporally stable single-sided sinking of an oceanic plate are high overall plate strength, a constantly, relatively thin plate, and a relatively strong decoupling from the underlying mantle (Crameri and Tackley, 2015). These conditions are elegantly enabled via small-scale convection (Conrad and Hager, 2001) in a low-viscosity asthenosphere (Richards et al., 2001).

Even though the sinking plate at shallow depth is still rather rigid compared to its weak surroundings, it often breaks and tears. Such plate failure at depth caused, for example, by a state of sudden resistance against the driving forces of subduction, can lead to slab windows (e.g., Guillaume et al., 2010) or even tears (e.g., Wortel and Spakman, 2000) and, in the most 
dramatic scenario, an entire slab-breakoff (Nemcok et al., 1998; Stampfli and Borel, 2002). Such scenarios are suggested to happen on present-day Earth, for example in the Mediterranean region (e.g., Wortel and Spakman, 2000), and are successfully reproduced and examined by laboratory modelling (e.g., Chemenda et al., 2000; Regard et al., 2005) and numerical modelling (e.g., Burkett and Billen, 2010; Duretz et al., 2012).

On its further way, down into the Earth's mantle, the oceanic plate crosses and interacts with multiple boundaries. A prominent boundary is the upperlower mantle transition zone at approximately $660 \mathrm{~km}$ depth (see e.g., Goes et al., 2017, and references therein). The shallow sinking plate (300-350 $\mathrm{km}$ ) is usually characterised by extensional focal mechanisms that indicate low slab-sinking resistance at these depths. In contrast, focal mechanisms at larger depth $(500-700 \mathrm{~km})$ indicate general plate compression (Isacks and Molnar, 1971; Richter, 1979; Apperson and Frohlich, 1987). This indicates an increase in slab-sinking resistance at these depths; and is commonly attributed to the upper-lower mantle transition zone. While some of Earth's sinking plates directly penetrate the transition zone and continue to sink into the lower mantle, others are seen to initially "stagnate" vertically above the transition zone or above around $1000 \mathrm{~km}$ depth (van der Hilst et al., 1991; Li and Romanowicz, 1996; Bijwaard et al., 1998; Grand, 2002; Fukao and Obayashi, 2013; Rudolph et al., 2015, and Figure 10). However, it is important to keep in mind that, even though they sometimes slow down significantly and even stall sinking, slabs never truly stagnate (Richard et al., 2006). The propensity of a sinking plate to directly enter the lower mantle depends on multiple factors. Direct penetration is fostered by a steep impinging angle of the slab at the transition zone (Kincaid and Olson, 1987) and, somewhat related, large negative slab buoyancy and low mobility of the overriding-plate and associated trench (Zhong and Gurnis, 1995; Christensen, 1996; Zhong and Gurnis, 1997). The metastability of pyroxene (Agrusta et al., 2014) and/or olivine (Schmeling et al., 1999) in cold slab cores might additionally prevent the slab from entering the lower mantle directly.

It is quite clear, and we have established it in Section 2, where the oceanic plate starts. It is, however, less obvious to define where an oceanic plate, that made its way all down into the lower mantle, ends. When an oceanic plate portion enters the high-viscosity lower mantle, it is forced to slow down dramatically. This causes, as mentioned above, a huge compression inside the slab in between its quickly sinking shallower and its slowly sinking deeper part. The slab reacts with buckling and compressional thickening (Gurnis 
and Hager, 1988; Ribe et al., 2007; Běhounková and Čǐžková, 2008; Lee and King, 2011). The resulting overall thickening upon arrival in the lower mantle is inferred from seismic observations on Earth and amounts to a factor between $2-5$. This corresponds to actual slab widths of around $400 \mathrm{~km}$ (Hafkenscheid et al., 2006; Ribe et al., 2007; Loiselet et al., 2010), but can possibly reach up to $700 \mathrm{~km}$ (Sigloch and Mihalynuk, 2013).

In the deep mantle lies the slab graveyard. The detailed structures of dying plates are not clearly visible anymore due to the inhibited or strongly reduced capabilities of seismic imaging techniques at these depths (see e.g., Figure 11 and Shephard et al., 2017). Yet, these deep slab remnants are believed to lose heat to the surrounding mantle, which widens the slab's profile in the mantle and weakens it. They are, however, still negatively buoyant and sink through the lower mantle at around $1-2 \mathrm{~cm} / \mathrm{yr}$ (Domeier et al., 2016). It appears, as if the dying, weak plate often separates into discrete, relatively smooth patches or slablets; likely a result of the ongoing diffusive heat exchange between slab and mantle and subsequent slab-weakening, but also due to eroding mantle flow, and the dynamic impact of the viscosity stratification in the mantle. If still intact, the asymmetry of the compositional stratification of the oceanic plate itself (high-density basalt on top of low-density harzburgite) would result in a significant torque to such sinking slablets, causing them to flip over and sink with the basalt-side facing downwards (Tackley, 2011). Finally, the basalt layer of the plate would likely segregate from the rest of the plate, especially after it has transformed to eclogite, and might, or might not, accumulate at the core-mantle boundary (CMB) as part of a bigger blob-like structure (e.g., Tackley, 1998, 2002; McNamara and Zhong, 2004, 2005; Deschamps and Tackley, 2008, 2009; Bull et al., 2009), visible as a Large-Low-Shear-Velocity-Province (LLSVP) (Kennett et al., 1998; Ishii and Tromp, 1999; Bolton and Masters, 2001; Ni et al., 2002; Trampert et al., 2004; Deschamps et al., 2007).

\subsection{The dynamic diversity of subduction}

Due to the structural heterogeneities described above, as well as other variables such as plate age during subduction, we observe an incredible diversity of forcing in a subduction system, which affects its overall dynamics. Indeed, this diversity is probably the major characteristic of a subducting plate: Subduction zones come in all shapes and forms, which additionally radically evolve over time. Here, we outline some of the most dominant variations within the subduction system. The dynamics in and around a sinking 
plate is controlled by many diverse physical aspects (see e.g., Billen, 2008; Gerya, 2011, and references therein). All these diverse aspects are here discussed as part of one of the three overarching aspects: geometry, forcing, and rheology.

The geometric variability of a subducting plate is highlighted in tomographic images of the sinking plates all around our planet (e.g., Fukao et al., 2001) and here visualised in Figure 11. The variable slab geometries that are observed (see e.g., the compilation of Lallemand et al., 2005, and Figure 12) have, for example, different slab lengths ranging from almost 0 (subduction of spreading ridges) up to around $1600 \mathrm{~km}$ length. Some slabs appear to directly penetrate into the lower mantle, while others are strongly deflected at the upper-mantle transition zone (see Section 4.2). In addition, dips of sinking plates are extremely diverse already near the Earth's surface (at around $125 \mathrm{~km}$ depth) with angles between 20 and 90 degrees. Continental upper plates seem thereby to foster shallow plate sinking at lower angles, possibly by active over-thrusting. Low shallow-slab dip might, however, also be due to a younger average subducting-plate age at the trench (see Figure 12), as younger plates are less negatively buoyant, or the weaker slab suction forces that go along with a thick (continental) upper plate and thinner mantle wedge (Tovish et al., 1978; van Hunen et al., 2004).

Plate bending, from the horizontal to a certain shallow-slab dip, is characterised by a strongly variable minimum bending radius of the plate at the trench. The (minimum) plate bending radii observed on present-day Earth have mean values of $390 \mathrm{~km}$ (Wu et al., 2008) or $175-191 \mathrm{~km}$ (Buffett and Heuret, 2011, and Figure 12) depending on the exact parameters of the spline that is fitted to the observed earthquake hypocentres, and seem to be uncorrelated with plate age (Buffett and Heuret, 2011), even though systematic analogue and numerical modelling suggests the opposite for steady-state plate subduction (Bellahsen et al., 2005; Capitanio et al., 2009).

The buoyancy variability of a subducting plate is somewhat controlled by variations in geometry (e.g., slab thickness and length; Conrad and LithgowBertelloni, 2002) but also by thermal and compositional aspects, some of which are outlined in Figure 12. Subduction is only self-maintaining, and hence viable, if the slab, or at least the largest part of it, is negatively buoyant relative to its surrounding mantle (as outlined in Section 4.1). The slab's buoyancy, however, varies strongly with plate age and structure. The plate age during subduction varies between nearly 0 (i.e., subduction of spreading ridges) and up to about 200 Ma (Becker et al., 2009; Coltice et al., 2012), 
while the plate structure varies, for example, significantly in terms of variable thicknesses of the light crustal layer inside the plate (see below). The negative slab buoyancy is the key ingredient to cause a resulting net slab pull. This excess weight of the slab is, however, also counteracted by, for example, the mantle viscosity (Conrad and Lithgow-Bertelloni, 2002, 2004); this is most obvious for parts of a slab interacting with the lower mantle. The resulting, net slab pull varies finally more than $60 \times 10^{12} \mathrm{~N} / \mathrm{m}$ (after the definition of Carlson et al., 1983).

Variations in net slab pull crucially affect the trailing-plate velocity $\left(v_{S U B}\right.$; see Figure 13), which ranges between $-4 \mathrm{~cm} / \mathrm{yr}$ and $12 \mathrm{~cm} / \mathrm{yr}$, and trench velocity $\left(v_{T R}\right)$, which ranges between $-9 \mathrm{~cm} / \mathrm{yr}$ and $15 \mathrm{~cm} / \mathrm{yr}$. High platevelocities and, even more clearly, trench-velocities are hampered by the presence of a continental upper plate (Figure 12). This is possibly due to the anchoring effect of deep continental roots extending the low-viscosity asthenosphere (Conrad and Lithgow-Bertelloni, 2006; Crameri and LithgowBertelloni, 2017). Moreover, buoyancy variations induce strong variations in (shallow and deep) slab dip angles (Vlaar and Wortel, 1976), slab bending radius (Buffett and Heuret, 2011), induced mantle-flow strength (Conrad and Lithgow-Bertelloni, 2002; Király et al., 2017), upper-plate deformation (Molnar and Atwater, 1978, see Figure 13) and long-wavelength surface topography (Crameri et al., 2017).

The rheological variability of a subducting plate strongly affects its strength, its weight, and its ability to transmit the slab pull force to the trailing plate, and thus ultimately exerts a key control on the plate dynamics. A stronger plate is, for example, generally harder to bend, which inhibits subduction, but at the same time may cause less dynamical coupling with the overriding plate and the surrounding mantle supporting subduction (e.g., Crameri and Tackley, 2015). The actual strength of the sinking plate itself depends on dominant deformation mechanisms, which are primarily controlled by the plate temperature, stress and strain rate. Whether plastic (i.e., brittle deformation), visco-plastic, or nonlinear viscous deformation becomes the dominant for plate deformation strongly depends therefore on the actual location of a certain plate portion within the plate-mantle system (e.g., Billen, 2008, and references therein). Brittle-plastic yielding is generally important in low temperature and confining-pressure environments, such as in regions of the plate that are at or close to Earth's surface. Brittle-plastic yielding in the upper part of the oceanic plate crucially facilitates bending during early subduction. At the same time, visco-plastic yielding is supporting and facil- 
itating the bending there as it is the main stress limiter in the lower parts of the plate (see e.g., Garel et al., 2014) and can even lead to shallow slab break-offs (Duretz et al., 2011).

On top of the plate, the weak crustal layer is a key rheological complexity (Cloos and Shreve, 1988). In a subduction zone, the crustal layer, or at least its upper-most part, is strongly deformed, hydrated, and surrounded by stronger crustal and other rocks (Bebout and Penniston-Dorland, 2016). As we already pointed out at various occasions in previous paragraphs, the crustal layer of the plate takes over multiple defining roles for the sinking of the plate: It is light and so resists plate sinking; it is weak and so facilitates plate bending; it is lubricating and so enables self-sustaining and single-sided plate subduction. Given that its thickness varies strongly spatially, the weak crustal layer contributes therefore also significantly to the high subduction variability.

Given a certain plate rheology, the subducting plate is still dependent on another important rheologic complexity, which involves its surrounding medium: A subducting plate does not sink into an empty space but is instead part of a bigger system that is the convecting mantle. As the subducting plate interacts strongly with the medium into which it is sinking, the rheologic properties of the surrounding mantle represent another crucial aspect of the dynamics of a subduction zone. Analogue and numerical experiments as well as observations of seismic anisotropy show that apart from Newtonian diffusion creep, other diverse flow mechanisms such as dislocation and Peierls creep could dominate deformation at pressure, temperature and strain-rate conditions of the upper mantle (Hirth and Kohlstedt, 1995; Kameyama et al., 1999; Kneller et al., 2005; van Hunen et al., 2005; Long and Silver, 2008). Non-Newtonian dislocation creep is likely dominant around the slab where the mantle is strongly sheared (e.g., Billen, 2008). This significantly reduces the resistance against plate sinking and so leads to faster sinking and also larger plate velocities (e.g., Crameri and Tackley, 2015), but reduced trenchretreat rates and steeper shallow-depth slab-dip angles (Holt and Becker, 2017).

Moreover, the dynamics of the sinking plate are strongly affected by the horizontal rheologic layering of the mantle. The upper-lower mantle transition zone, and in particular the $660-\mathrm{km}$ discontinuity, dramatically affects the forcing and geometry of a subduction system (see e.g., Goes et al., 2017, and references therein). This transition is characterised by both a sudden increase in radial viscosity and density, both of which hamper the sinking 
of the oceanic plate (see Section 4.2). The density contrast (between slab and lower mantle) can be so strong that the sinking plate slowly bounces off the transition zone and interrupts its vertical sinking temporally. At what depths and by how much these mantle properties change exactly is still not entirely clear (e.g., Rudolph et al., 2015).

Considering all of the above variabilities in geometry, buoyancy and rheology, it becomes clear - and it is important to remind us of it repeatedly - that the sinking plate is one of the most geometrically variable large-scale features of our planet. It bends, twists, thins, tears, thickens and buckles throughout all three spatial dimensions. Characterising a subduction zone on the basis of a vertical cross-section can therefore be rather meaningless without incorporating the huge variations along its strike direction. And as if the above varieties were not enough, all of these properties change over time too; the strong time-dependence of subduction is another crucial complexity. But despite all of this incredible dynamic variation, one aspect is universal to all subduction zones: The sinking plate portion is the locomotive of the trailing oceanic plate (Forsyth and Uyeda, 1975; Conrad and Lithgow-Bertelloni, 2002), and as such, also the main driver of mobile-lid mantle convection.

\subsection{Consequences of the sinking plate}

Downward bending and sinking into the mantle is probably most dramatic and most influential stage of the oceanic plate: The process of subduction is accompanied by unprecedented mechanical, thermal - and if it were not enough - compositional events. Much like a last effort, the deforming and warming oceanic plate reacts with intense seismic and magmatic activities while driving itself unstoppable further down into the hot and mixing depths of the planet. Before the oceanic plate is heated and stirred back into the mantle, the sinking oceanic plate has important consequences for its surroundings, and indeed the whole planet.

\subsubsection{Consequences of the shallow slab}

At the surface, the plate collision zone is clearly outlined by a characteristic, asymmetric topographic scar (e.g., Figure 10a). When the subducting plate approaches the convergent boundary, the first topographic appearance of the convergent boundary is the viscous fore-bulge (or outer rise); the transient, viscous uplift outboard of the trench caused by the downward bending of the subducting plate that floats on a low-viscosity mantle (de Bremaecker, 1977). Its height is mostly controlled by the shallow-slab dip (Crameri et al., 
2017). The fore-bulge is directly followed by a deep subduction trench that marks the interface between the upper- and lower plate. It can reach up to $11 \mathrm{~km}$ depth below sea level (e.g., Nakanishi and Hashimoto, 2011). The trench is a direct consequence of the downward pull of the subducted plate portion and influenced therefore by slab length and plate age at the trench, but also by the subduction-fault dip and shallow-slab dip angles (e.g., Zhong and Gurnis, 1994). Amongst all of these, the two key controls are the dip angle of the oceanic plate at shallow depth followed by the regional net slab pull (Jarrard, 1986; Crameri et al., 2017). At an ocean-ocean collision zone, the trench is followed by the island-arc (or volcanic arc), which is a high on the upper plate that is caused by local horizontal compression resulting from the collisional plate interface. As such it is mostly controlled by the local plate strength (Crameri et al., 2017). Apart from its dynamic origin, the island-arc can also be strongly affected by volcanism (Karig, 1971) and focusing of melt by the thermal structure of the upper plate (England and Katz, 2010; Rondenay et al., 2010). Following the island-arc, and marking the end of the topographic scar, is the back-arc depression (or basin). It is the downward deflection of the upper plate above the sinking slab. This regional deflection is mainly caused by upper plate extension, but also due to the dynamic coupling with the sinking slab below. Near-surface slab dip and buoyancy, and mantle wedge viscosity are therefore the three major agents controlling the depth of the depression (Billen and Gurnis, 2001; Crameri et al., 2017). Back-arcs do not only deflect vertically but can also be under compression or extension laterally. The latter case can even lead to episodic back-arc spreading, where the upper plate is torn apart (Karig, 1971; Uyeda and Kanamori, 1979; Carlson and Melia, 1984; Heuret and Lallemand, 2005). This state, with the two upper-plate parts moving away from each other, is mostly controlled by horizontal tectonic stresses arising at the subduction zone (Ruff and Kanamori, 1980; Heuret et al., 2012; Magni et al., 2014).

Apart from deflecting the surface, the old oceanic plate portion causes, during its downward travel into the Earth, huge earthquakes, fluid release and - despite its cold nature - lava-spitting volcanoes. In fact, the largest earthquakes ever recorded took place along the plate boundary at subduction zones. The internal deformation of the oceanic plate during subduction is another important source of earthquakes. The bending and unbending involved in subducting an oceanic plate exerts enormous stresses on the plate, especially on its upper-most, brittle part (see e.g., Figure 10d). It is therefore not surprising that earthquakes steadily originate in a narrow band inside 
the upper part of the sinking plate. This seismically active band outlines the internal plate deformation along the slab and is called the Wadati Benioff Zone (Wadati, 1935; Benioff, 1949). This zone can reach down to $660 \mathrm{~km}$ depth and its detection was one of the first indicators for the characteristic, single-sided geometry of sinking oceanic plates.

Subduction-induced flow in the mantle is a crucial consequence of the sinking plate and comes with different strengths and patterns (see Figure 1 and e.g., Jadamec, 2016, and references therein). One way the sinking plate induces flow in the surrounding mantle is through viscous coupling (Garfunkel et al., 1986). As the sinking plate motion is predominantly downdip in slabparallel direction and involves little horizontal rotation, the flow induced by viscous coupling is mostly poloidal; one convection cell in the back, and one cell in the front of the slab. The latter causes a "trench suction", a drag on the upper plate induced by the shallow mantle return flow that originates from the sinking of the plate (Garfunkel et al., 1986). When an inclined plate sinks, as is usually the case in the upper mantle, it creates a pressure gradient between the back and the front of the slab that influences slab dip (McKenzie, 1969; Tovish et al., 1978). This pressure difference is also the cause of both an additionally induced, toroidal flow of mantle material, mostly around the slab's edges (e.g., Funiciello et al., 2003, 2004; Schellart, 2004; Piromallo et al., 2006; Stegman et al., 2010a; Jadamec and Billen, 2010; Capitanio and Faccenda, 2012), and a trench-parallel flow in the back of the slab (Russo and Silver, 1994; Kneller and van Keken, 2007; Long and Silver, 2009; Paczkowski et al., 2014). The combination of the latter, trench-parallel flow and the poloidal component then actually causes a 3-D flow spiral in the back of sinking plates (Crameri and Tackley, 2014, and highlighted in Figure 1).

Why the cold sinking plate causes hot surface volcanism is still not quite clear. However, apart from possible triggers like the fluid release from the plate that lowers the melting point of the surrounding mantle rocks (e.g., Anderson et al., 1976) or the additional heat produced by the deformation along the plate interface (e.g., Yuen et al., 1978), subduction-induced mantle flow seems to be a likely important candidate (e.g., Marsh, 1979): The subduction-induced mantle flow draws, in particular, low-viscosity, hot material to the shallow mantle wedge (e.g., Schellart, 2004; Piromallo et al., 2006; Faccenna et al., 2010; Jadamec and Billen, 2010). A toroidal flow cell around a sinking-plate edge even has the potential to significantly influence its neighbouring plate, if they are less than around $600 \mathrm{~km}$ away from each 
other (Király et al., 2016).

The most influential impact of the subduction-induced toroidal flow comes, however, from a dynamic feedback on the sinking plate portion itself: The mantle flow causes the slab to deform. Most sinking portions of oceanic plates have a characteristic arcuate shape (concave towards the mantle wedge), which is even visible at the surface where the subduction trench displays the similar, translated geometry of the slab (see e.g., Sdrolias and Müller, 2006). Even though it is still widely believed, and still the common explanation given in textbooks, subduction zones are not arcuate because of what has been named the "ping-pong ball effect" (Frank, 1968). The ping-pong ball analogy describes the presumed geometric similarity between a subducting plate and a circular indentation on a dented ping-pong ball. Even though it is an elegant analogy, its geometrical attribute, a specific relationship between arc-radius and slab-dip (i.e., the steeper the dip, the larger the bending radius of the arc), is not matched at all by the majority of Earth's subduction zones (e.g., Tovish and Gerald, 1978; Morra et al., 2006). The observed curvature of oceanic trenches can, in contrast, be fully explained by the combination of plate-internal heterogeneities and external feedback from the induced flow in the surrounding mantle (Morra et al., 2006). Indeed, it has been shown that subduction zones are arcuate due to the induced mantle flow in their surrounding: Subduction models run in Cartesian boxes indicate the arcuate shape to be the natural state of a dynamically evolving subducting plate, even in a flat (i.e., non-spherical) Earth (Crameri and Tackley, 2014).

The feedback with the subduction-induced mantle flow does also explain the observation of multiple-arc geometry of wide subducting plates. In the case of a wide slab, the mantle in the back-slab region cannot be displaced efficiently anymore laterally along the slab strike and around the edges (as outlined in detail above). Instead, it forms a stagnation zone somewhere near the central part of the slab (e.g., Russo and Silver, 1994; Schellart et al., 2007). Such a stagnation zone can cause the retreating slab to tightly deflect around it, which then ultimately leads to a typical narrow convex kink in between two otherwise concavely arcuate slab portions (Crameri and Tackley, 2014). The wide, multi-arcuate South America subduction system is a classic example (e.g., Russo and Silver, 1994; Schellart et al., 2008). If the stagnation zone persists and the intact slab continues to retreat, it can tear, or, if it stays intact, even lead to a 'slab tunnel' (Crameri and Tackley, 2014). Either way opens a door for the trapped mantle material to finally escape the high-pressure region in the back of the slab as is, for example, 
observed for the Nazca slab (e.g., Lynner et al., 2017).

Even though the plate is bent strongly (in vertical and horizontal direction), it can usually maintain its structural integrity during its sinking through the upper mantle. This enables the transmission of stress along the sinking slab. The stress transmission along the slab and the slab's body force are the two crucial dynamic ingredients for plate tectonics like on Earth. The sinking portions of oceanic plates are steadily rearranging the tectonic puzzle on the surface, merging continents and divorcing them again.

\subsubsection{Consequences of the deep slab}

In the deeper parts of subduction zones, the oceanic plate undergoes various crystallographic mutations. The transformation of light crustal basalt to denser eclogite at depth greater than around $60 \mathrm{~km}$, for example, provides an additional pull to the trailing oceanic plate (Ringwood and Green, 1966). In contrast, the delayed transformation of ringwoodite to bridgmanite and ferropericlase (e.g., Bina, 1991) in the cold sinking-plate core compared to the hot surrounding mantle provides crucial resistance against the plate sinking beyond $660 \mathrm{~km}$ depth, because it temporarily reverses the density contrast between sinking plate and surrounding mantle. In fact, the resistance is so strong that some slabs are strongly deflected and might even pause for a while before they further sink into the deep mantle (van der Hilst et al., 1991; Li and Romanowicz, 1996; Bijwaard et al., 1998; Grand, 2002; Fukao and Obayashi, 2013; Goes et al., 2017, and Section 4.2). The physics involved in the slab-transition zone collision has been studied extensively for slab tongue deformation (i.e., the bending, buckling and thickening of the leading slab-tip portion Ribe et al., 2007; Běhounková and Č́žková, 2008; Ribe, 2010; Stegman et al., 2010b; Lee and King, 2011; Li and Ribe, 2012) and the dynamic consequences of intermediate slab stagnation (Kincaid and Olson, 1987; Griffiths et al., 1995; Zhong and Gurnis, 1995; Christensen, 1996; Zhong and Gurnis, 1997; Funiciello et al., 2003; Čížová and Bina, 2013; Garel et al., 2014; Agrusta et al., 2014, 2017; Crameri and LithgowBertelloni, 2017). Crameri and Lithgow-Bertelloni (2017) showed that the interaction of the sinking plate with the upper-mantle transition zone can even lead to an abrupt continental-wide tilt at the surface above.

Even though some slabs stagnate for a while at the upper-lower mantle transition zone, this is not a stable state of the deep oceanic plate. The instability process bringing temporarily stagnant slabs deeper into the lower mantle is commonly referred to as slab- or mantle avalanches (e.g., Nakakuki 
et al., 2010). Slab avalanches have, for example, been suggested to have caused the significant transitions in mantle-flow patterns and and deformation styles in the Southwest Pacific (Pysklywec et al., 2003) and in Southeast Asia (Yang et al., 2016).

Such crucial interaction of the slab with the surface is a late, but not yet the last signal of the old, descending oceanic plate from the deep mantle. Even though the deep sinking slab and any broken-apart slablets are constantly getting warmer, widened, and weakened (see Section 4.2), they remain negatively buoyant (e.g., Conrad and Hager, 1999) and eventually come to rest in "slab graveyards" in the deepest mantle (Spasojevic et al., 2010, and Figure 11). These negatively buoyant last remnants of the oceanic plate are therefore still part of the primary energy source that drives globalscale mantle flow and the associated surface plate motions (e.g., Becker and O'Connell, 2001; Conrad and Lithgow-Bertelloni, 2002, 2004). The impact of this global flow can be felt at all depths, ranging from the interaction with the LLSVPs at the base of the mantle (e.g., Burke et al., 2008; Dziewonski et al., 2010; Steinberger and Torsvik, 2012; Conrad et al., 2013) to $\sim 1 \mathrm{~km}$ dynamic topography at the Earth's surface (e.g., Flament et al., 2013). The core-mantle boundary is, then eventually, the final ocean-plate graveyard: It is where slabs become finally reheated and their materials recycled back into the rest of the mantle system (Torsvik et al., 2016).

\section{Ocean-Plate Tectonics}

\subsection{A more specific, more integral concept}

Oceanic plates are operational at space and time scales beyond the regular range of human experience. Tiny defects in micrometer-sized crystals enable the movement of plates that are, in contrast, thousands of kilometres wide. The fleetingly short slips happening over a few seconds at seismogenic, convergent plate boundaries are an expression of the sluggish plate drift that happens over millions of years. Because such deformations are not easily observed on human time scales, and because they mostly occur beneath seawater and sediments, the discovery of the ocean plates took an unusually long time, despite their planetary importance. Indeed, their behaviour is still not fully understood.

The dynamic life of the oceanic plate, outlined in detail above, from its formation through cooling to its destruction (Figure 1), is at the centre of Plate Tectonics, the fundamental theory developed around fifty years 
ago (Hess, 1962). Back then, the theory of Plate Tectonics described the horizontal dynamics of the outermost shell of the solid, convecting Earth (Holmes, 1931) and explained the motions of continents (Wegener, 1912) and the symmetrically undulating paleo-magnetic striping of the seafloor at mid-ocean ridges (e.g., Mason, 1958; Vine and Matthews, 1963). 'Plate Tectonics' was - and still is - simply and solely defining the horizontal kinematics of multiple discrete, mostly rigid surface plates, while necessitating the three end-members of weak and narrow plate boundaries that allow for divergence, convergence and shearing. As such, the concept of plate tectonics captures neither the crucial differences between the oceanic and continental plates, nor the forcing behind their horizontal movement across the surface. Missing also from the traditional definition is the integral role that oceanic plates play within the framework of mantle convection on Earth.

Since plate tectonics was originally defined, our knowledge of the underlying processes of plate tectonics has, however, been greatly enhanced by more detailed observations on Earth (plates are not entirely rigid and plate boundaries can be diffuse (Gordon, 1998); plates are not always entirely oceanic or continental; some oceanic plates may be lacking either subducting or spreading boundaries), through comparisons with similar and contrasting surface behaviours of other planetary bodies (mantle convection with mobile surface plates is only one of many possible ways for a silicate planet to cool), and via analogue and numerical modelling (slabs drive the plates; continuously mobile plates appear only in a narrow range of parameter space). Given these advances, the tectonics of the oceanic plate therefore needs a more focused (distinguishing between continental and oceanic plate nature), a more complete (including framework and forcing), and indeed a more sophisticated description than that was possible 50 years ago.

The oceanic plate, as we understand it today, is not merely characterised by an autonomous, isolated horizontal movement at the planet's surface, but is instead intimately linked to the drift of its continental counterparts (Wilson, 1966; Burke, 2011), mantle convection (Turcotte and Oxburgh, 1972), and indeed to the whole system Earth (see e.g., Torsvik and Cocks, 2016b, and references therein). The oceanic plate is not only part of the cold thermal boundary layer of the hot convecting mantle bridging the solid interior with the oceans and atmosphere above (see Bercovici, 2003; Coltice et al., 2017, and references therein) but, moreover, it is an integral and active part of the convective mantle overturn: It is formed from upwelling mantle material (see Section 2) and pulled horizontally across the surface (see Section 3) mainly 
by its own subducted portion that is eventually destroyed in the deep mantle again (see Section 4). Such additional insights gained from more than fifty years of research allow for a new, more refined and more integral definition. This definition should not only recognise the recent "revolution" in the Geosciences that casts plate tectonics within the framework of mantle convection (Torsvik and Steinberger, 2006, 2008), but also pave the way for future advances by bringing currently diverging perceptions of 'Plate Tectonics' back to a common ground:

Definition. 'Ocean-Plate Tectonics' is a mode of mantle convection characterised by the autonomous relative movement of multiple discrete, mostly rigid, portions of oceanic plates at the surface, driven and maintained principally by subducted parts of these same plates that are sinking gravitationally back into Earth's interior and deforming the mantle interior in the process.

\subsection{Emergence}

Strongly linked to how we define 'Ocean-Plate Tectonics' is also the question of whether Ocean-Plate Tectonics was always present on Earth, or, if not, when it started (see e.g., Stern, 2007; Condie and Pease, 2008). One unavoidable outcome of the dynamic life of the oceanic plate is that it is always erasing its traces efficiently and continuously (see Section 4). Yet, tiny bits and traces of past plates are remaining today and provide at least some constraints on the beginnings of plate tectonics: Tiny parts of the oceanic plate (i.e., ophiolites) have, for example, been emplaced on continents, the more enduring, long-lived parts of Earth's surface, and therefore escaped destruction. These informative ophiolites record both plate formation (see Section 2) and relative plate movement. Convincing ophiolite samples have a maximum age of around $1 \mathrm{Gyr}$, with some less convincing samples dating back further than 2 Ga (e.g., Scott et al., 1992). There is also evidence for deep subduction (which is, per definition, one necessity for Ocean-Plate Tectonics) back to nearly $1 \mathrm{Ga}$ from the oldest blueschists found on Earth, which have ages of around $800-700$ Myr (Maruyama et al., 1996). Samples like these support the operation of Ocean-Plate Tectonics with modern-style subduction for at least the past billion years (Brown, 2006). The absence of similar samples with older ages does not, however, mean that they never existed: They simply might not have been preserved.

But would Ocean-Plate Tectonics be viable at all on the early Earth (see van Hunen et al., 2008, and references therein)? Theoretical considerations 
suggest that this would not be the case at least for the very young, Archean Earth. The Archean mantle at 2.5 - 3.8 Ga was certainly hotter than it is presently due to more heat from early (> $4 \mathrm{Ga}$ ) radioactive decay, accretion, core differentiation, large planetesimal impacts (e.g., moon-forming event), and a hotter sun (during its T Tauri phase; e.g., Bertout, 1989). The resulting lithosphere in between such a hot atmosphere and mantle would also be hotter, and hence thinner and more buoyant while the crust would be thicker than today (Figure 6), making Ocean-Plate Tectonics less viable (see Section 4.1.1). Additionally, a hotter and thinner plate would be weaker and more prone to lithosphere-scale failure, which would create more spreading ridges (see Section 2.1) and inhibit the style of subduction we observe today (see Section 4.1). So, if there were an early plate (i.e., no magma ocean) and relative plate movement (i.e., no rigid stagnant lid), surface deformation might instead result from drip- (Davies, 1992) or blob-like-subduction tectonics (Crameri and Tackley, 2015), ridge-only tectonics (Rozel et al., 2015), or inefficient short-slab tectonics (Davaille et al., 2017) that may currently be operating on Venus (Sandwell and Schubert, 1992; Schubert and Sandwell, 1995) and might have, on Early Earth, been triggered at the edges of collapsing continents (Rey et al., 2014).

When during Earth's history such a different style of tectonics transitioned into the present-day deep-subduction style of Ocean-Plate Tectonics, and whether this happened suddenly or gradually, is not yet clear (Brown, 2008). However, there appear to be two major shifts in the products of Earth's surface tectonics during its evolution: First, a change in net growth rate of continental crust is apparent at around $3 \mathrm{Ga}$ (Dhuime et al., 2015), and second, preservation of ophiolites and ultra-high-pressure rocks are associated with a dramatic change of climate and true-polar wander at around $1-0.5 \mathrm{Ga}$ (see e.g., Torsvik and Cocks, 2016a, and references therein). Both

of these events may (or may not) be associated with the invention of OceanPlate Tectonics.

\subsection{Closing}

It has become clear that comprehending Earth evolution and dynamics requires a fundamental understanding of whole mantle-convection and, indeed, the whole planetary system. This understanding begins with the oceanic plate. After all, it is the most fascinating dynamic earmark of our planet. It is a transporter to the heat, a recycler to volatiles, a mixer to the interior, a 
sculptor to surfaces, a mother to life. It is the oceanic plate, the drumming pyromaniac of the underworld.

\section{Acknowledgment}

The authors thank Grace Shephard for providing Figure 11 and Hailong Bai for compiling the data in Figure 3. The authors also thank three anonymous reviewers for their constructive comments that helped to improve this manuscript. This work was partly supported by the Research Council of Norway Centres of Excellence project 223272. Computation time was provided by the Norwegian computational infrastructure (sigma2) via allocations NN9283K and NS9029K.

\section{Bibliography}

Abbott, D., R. Drury, and W. H. F. Smith (1994), Flat to steep transition in subduction style, Geology, 22(10), 937-940.

Adam, C., S. King, V. Vidal, M. Rabinowicz, A. Jalobeanu, and M. Yoshida (2015), Variation of the subsidence parameters, effective thermal conductivity, and mantle dynamics, Earth and Planetary Science Letters, 426, 130-142, doi:10.1016/j.epsl.2015.06.025.

Agrusta, R., J. van Hunen, and S. Goes (2014), The effect of metastable pyroxene on the slab dynamics, Geophys. Res. Lett., 41(24), 8800-8808.

Agrusta, R., S. Goes, and J. van Hunen (2017), Subducting-slab transitionzone interaction: Stagnation, penetration and mode switches, Earth and Planetary Science Letters, 464, 10-23, doi:10.1016/0040-1951(85)90209-4.

Albers, M., and U. R. Christensen (2001), Channeling of plume flow beneath mid-ocean ridges, Earth and Planetary Science Letters, 187(1), 207-220, doi:10.1016/S0012-821X(01)00276-X.

Almalki, K. A., P. G. Betts, and L. Ailleres (2016), Incipient seafloor spreading segments: Insights from the Red Sea, Geophys. Res. Lett., 43(6), 27092715, doi:10.1002/2016GL068069. 
Alt, J. C. (1995), Subseafloor processes in mid-ocean ridge hydrothermal systems, in Seafloor Hydrothermal Systems: Physical, Chemical, Biological, and Geological Interactions, 91, pp. 85-114, American Geophysical Union, doi:10.1029/GM091p0085.

Amante, C., and B. Eakins (2009), ETOPO1 1 arc-minute global relief model: Procedures, data sources and analysis, NOAA Technical Memorandum NESDIS NGDC-24, National Geophysical Data Center, NOAA, Colorado, doi:10.7289/V5C8276M.

Anderson, R. N., S. Uyeda, and A. Miyashiro (1976), Geophysical and geochemical constraints at converging plate boundaries-Part I: Dehydration in the downgoing slab*, Geophysical Journal of the Royal Astronomical Society, 44 (2), 333-357, doi:10.1111/j.1365-246X.1976.tb03660.x.

Apperson, K. D., and C. Frohlich (1987), The relationship between WadatiBenioff Zone geometry and $\mathrm{P}, \mathrm{T}$ and $\mathrm{B}$ axes of intermediate and deep focus earthquakes, J. Geophys. Res., 92(B13), 13,821-13,831, doi: 10.1029/JB092iB13p13821.

Arculus, R. J., O. Ishizuka, K. A. Bogus, M. Gurnis, R. Hickey-Vargas, M. H. Aljahdali, A. N. Bandini-Maeder, A. P. Barth, P. A. Brandl, L. Drab, R. do Monte Guerra, M. Hamada, F. Jiang, K. Kanayama, S. Kender, Y. Kusano, H. Li, L. C. Loudin, M. Maffione, K. M. Marsaglia, A. McCarthy, S. Meffre, A. Morris, M. Neuhaus, I. P. Savov, C. Sena, F. J. Tepley III, C. van der Land, G. M. Yogodzinski, and Z. Zhang (2015), A record of spontaneous subduction initiation in the Izu-Bonin-Mariana arc, Nature Geosci, 8(9), 728-733.

Ashwal, L. D., M. Wiedenbeck, and T. H. Torsvik (2017), Archaean zircons in Miocene oceanic hotspot rocks establish ancient continental crust beneath Mauritius, Nature Communications, 8, 14,086, doi:10.1038/ncomms14086.

Asimow, P. D., and C. Langmuir (2003), The importance of water to oceanic mantle melting regimes, Nature, 421(6925), 815.

Asimow, P. D., M. M. Hirschmann, and E. M. Stolper (2001), Calculation of peridotite partial melting from thermodynamic models of minerals and melts, IV. Adiabatic decompression and the composition and mean properties of mid-ocean ridge basalts, Journal of Petrology, 42(5), 963-998, doi:10.1093/petrology/42.5.963. 
Baba, K., A. D. Chave, R. L. Evans, G. Hirth, and R. L. Mackie (2006), Mantle dynamics beneath the East Pacific Rise at 17S: Insights from the mantle electromagnetic and tomography (MELT) experiment, J. Geophys. Res., 111(B2), n/a-n/a, doi:10.1029/2004JB003598.

Bai, H. (2017), Melt extraction and crustal thickness variations at segmented mid-ocean ridges, Ph.D. thesis, University of Maryland, doi: doi:10.13016/M2GT5FG2S.

Bai, H., and L. G. J. Montési (2015), Slip-rate-dependent melt extraction at oceanic transform faults, Geochem. Geophys. Geosyst., 16(2), 401-419, doi:10.1002/2014GC005579.

Baker, E. T., H. N. Edmonds, P. J. Michael, W. Bach, H. J. B. Dick, J. E. Snow, S. L. Walker, N. R. Banerjee, and C. H. Langmuir (2004), Hydrothermal venting in magma deserts: The ultraslow-spreading Gakkel and Southwest Indian Ridges, Geochem. Geophys. Geosyst., 5(8), doi: 10.1029/2004GC000712.

Barnouin-Jha, K., E. M. Parmentier, and D. W. Sparks (1997), Buoyant mantle upwelling and crustal production at oceanic spreading centers: Onaxis segmentation and off-axis melting, J. Geophys. Res., 102(B6), 11,97911,989, doi:10.1029/96JB03807.

Batchelor, G. K. (1967), An introduction to fluid dynamics, Cambridge University Press.

Bebout, G. E., and S. C. Penniston-Dorland (2016), Fluid and mass transfer at subduction interfaces-The field metamorphic record, Lithos, 240-243, 228-258, doi:10.1016/j.lithos.2015.10.007.

Becker, T. W., and C. Faccenna (2011), Mantle conveyor beneath the Tethyan collisional belt, Earth and Planetary Science Letters, 310 (3), 453461, doi:10.1016/j.epsl.2011.08.021.

Becker, T. W., and R. J. O'Connell (2001), Predicting plate velocities with mantle circulation models, Geochem. Geophys. Geosyst., 2(12), doi: 10.1029/2001GC000171.

Becker, T. W., C. P. Conrad, B. Buffett, and R. D. M'uller (2009), Past and present seafloor age distributions and the temporal evolution of plate 
tectonic heat transport, Earth and Planetary Science Letters, 278(3), 233242.

Behn, M. D., and T. L. Grove (2015), Melting systematics in mid-ocean ridge basalts: Application of a plagioclase-spinel melting model to global variations in major element chemistry and crustal thickness, J. Geophys. Res. Solid Earth, 120(7), 4863-4886, doi:10.1002/2015JB011885.

Behn, M. D., J. Lin, and M. T. Zuber (2002), Evidence for weak oceanic transform faults, Geophys. Res. Lett., 29(24), 60-1-60-4, doi: 10.1029/2002GL015612.

Behn, M. D., J. Lin, and M. T. Zuber (2004), Effects of Hydrothermal Cooling and Magma Injection on Mid-Ocean Ridge Temperature Structure, Deformation, and Axial Morphology, in Mid-Ocean Ridges: Hydrothermal Interactions Between the Lithosphere and Oceans, Geophys. Monogr. Ser., vol. 148, edited by C. German, J. Lin, and L. Parson, pp. 151-165, American Geophysical Union, doi:10.1029/148GM06.

Behn, M. D., M. S. Boettcher, and G. Hirth (2007), Thermal structure of oceanic transform faults, Geology, 35(4), 307-310, doi:10.1130/g23112a.1.

Bellahsen, N., C. Faccenna, and F. Funiciello (2005), Dynamics of subduction and plate motion in laboratory experiments: Insights into the "plate tectonics" behavior of the Earth, J. Geophys. Res., 110(B1), n/a-n/a.

Bellahsen, N., S. Leroy, J. Autin, P. Razin, E. d'Acremont, H. Sloan, R. Pik, A. Ahmed, and K. Khanbari (2013), Pre-existing oblique transfer zones and transfer/transform relationships in continental margins: New insights from the southeastern gulf of aden, socotra island, yemen, The Gulf of Aden rifted margins system: Special Issue dedicated to the YOCMAL project (Young Conjugate Margins Laboratory in the Gulf of Aden), 607(Supplement C), 32-50, doi:10.1016/j.tecto.2013.07.036.

Benioff, H. (1949), Seismic evidence for the fault origin of oceanic deeps, Geological Society of America Bulletin, 60(12), 1837-1856.

Bercovici, D. (1998), Generation of plate tectonics from lithosphere-mantle flow and void-volatile self-lubrication, Earth and Planetary Science Letters, 154(1-4), 139-151. 
Bercovici, D. (2003), The generation of plate tectonics from mantle convection, Earth and Planetary Science Letters, 205(3-4), 107-121, doi: 10.1016/S0012-821X(02)01009-9.

Bercovici, D., and Y. Ricard (2005), Tectonic plate generation and twophase damage: Void growth versus grain size reduction, J. Geophys. Res., 110 (B3), B03,401.

Bercovici, D., and Y. Ricard (2013), Generation of plate tectonics with twophase grain-damage and pinning: Source-sink model and toroidal flow, Earth and Planetary Science Letters, 365(0), 275-288.

Bercovici, D., and Y. Ricard (2014), Plate tectonics, damage and inheritance, Nature, 508(7497), 513-516.

Bercovici, D., Y. Ricard, and M. A. Richards (2000), The relation between mantle dynamics and plate tectonics: A Primer, in Geophys. Monogr. Ser., vol. 121, pp. 5-46, AGU, Washington, DC.

Bertout, C. (1989), T Tauri stars: Wild as dust, Annual Review of Astronomy and Astrophysics, $27(1), 351-395$.

Bickle, M. J. (1986), Implications of melting for stabilisation of the lithosphere and heat loss in the Archaean, Earth and Planetary Science Letters, 80(3), 314-324, doi:10.1016/0012-821X(86)90113-5.

Bijwaard, H., W. Spakman, and E. R. Engdahl (1998), Closing the gap between regional and global travel time tomography, J. Geophys. Res., $103(\mathrm{~B} 12)$, 30,055-30,078.

Billen, M. I. (2008), Modeling the dynamics of subducting slabs, Annu. Rev. Earth Planet. Sci., 36(1), 325-356, doi: 10.1146/annurev.earth.36.031207.124129.

Billen, M. I., and M. Gurnis (2001), A low viscosity wedge in subduction zones, Earth and Planetary Science Letters, 193(1-2), 227-236.

Bina, C. R. (1991), Mantle discontinuities, Reviews of Geophysics Supplement, 29, 783-793. 
Boettcher, M. S., and T. H. Jordan (2004), Earthquake scaling relations for mid-ocean ridge transform faults, J. Geophys. Res., 109(B12), doi: 10.1029/2004JB003110.

Bolton, H., and G. Masters (2001), Travel times of P and S from the global digital seismic networks: Implications for the relative variation of $\mathrm{P}$ and $\mathrm{S}$ velocity in the mantle, J. Geophys. Res., 106(B7), 13,527-13,540, doi: 10.1029/2000JB900378.

Bonatti, E. (1985), Punctiform initiation of seafloor spreading in the Red Sea during transition from a continental to an oceanic rift, Nature, 316(6023), 33-37.

Bonatti, E., M. Ligi, A. M. Borsetti, and L. Gasperini (1996), Lower cretaceous deposits trapped near the equatorial Mid-Atlantic Ridge, Nature, $380(6574), 518$.

Bosch, D., M. Jamais, F. Boudier, A. Nicolas, J.-M. Dautria, and P. Agrinier (2004), Deep and high-temperature hydrothermal circulation in the Oman ophiolite-petrological and isotopic evidence, Journal of Petrology, 45(6), 1181-1208.

Braun, M. G., and P. B. Kelemen (2002), Dunite distribution in the Oman ophiolite: Implications for melt flux through porous dunite conduits, Geochemistry, Geophysics, Geosystems, 3(11), 1-21, doi: 10.1029/2001GC000289.

Braun, M. G., G. Hirth, and E. M. Parmentier (2000), The effects of deep damp melting on mantle flow and melt generation beneath mid-ocean ridges, Earth and Planetary Science Letters, 176(3), 339-356.

Briais, A., and M. Rabinowicz (2002), Temporal variations of the segmentation of slow to intermediate spreading mid-ocean ridges 1. Synoptic observations based on satellite altimetry data, Journal of Geophysical Research: Solid Earth, 107(B5).

Brown, M. (2006), Duality of thermal regimes is the distinctive characteristic of plate tectonics since the Neoarchean, Geology, 34(11), 961-964, doi: 10.1130/G22853A.1. 
Brown, M. (2008), Characteristic thermal regimes of plate tectonics and their metamorphic imprint throughout Earth history: When did Earth first adopt a plate tectonics mode of behavior, in When Did Plate Tectonics Begin on Planet Earth?, edited by K. C. Condie and V. Pease, Geological Society of America, doi:10.1130/2008.2440(05).

Buck, W. R., and W. Su (1989), Focused mantle upwelling below mid-ocean ridges due to feedback between viscosity and melting, Geophysical Research Letters, 16(7), 641-644.

Buffett, B. A. (2006), Plate force due to bending at subduction zones, Journal of Geophysical Research: Solid Earth, 111(B9), doi: 10.1029/2006JB004295, b09405.

Buffett, B. A., and A. Heuret (2011), Curvature of subducted lithosphere from earthquake locations in the Wadati-Benioff zone, Geochem. Geophys. Geosyst., 12(6), doi:10.1029/2011GC003570.

Bull, A. L., A. K. McNamara, and J. Ritsema (2009), Synthetic tomography of plume clusters and thermochemical piles, Earth and Planetary Science Letters, 278(3), 152-162, doi:10.1016/j.epsl.2008.11.018.

Burke, K. (2011), Plate Tectonics, the Wilson Cycle, and Mantle Plumes: Geodynamics from the top, Annu. Rev. Earth Planet. Sci., 39(1), 1-29, doi:10.1146/annurev-earth-040809-152521.

Burke, K., B. Steinberger, T. H. Torsvik, and M. A. Smethurst (2008), Plume Generation Zones at the margins of Large Low Shear Velocity Provinces on the core-mantle boundary, Earth and Planetary Science Letters, 265(1-2), 49-60, doi:10.1016/j.epsl.2007.09.042.

Burkett, E. R., and M. I. Billen (2010), Three-dimensionality of slab detachment due to ridge-trench collision: Laterally simultaneous boudinage versus tear propagation, Geochem. Geophys. Geosyst., $11(11)$, Q11,012.

Burov, E., and S. Cloetingh (2010), Plume-like upper mantle instabilities drive subduction initiation, Geophys. Res. Lett., 37 (3), L03,309.

Burov, E., and T. Gerya (2014), Asymmetric three-dimensional topography over mantle plumes, Nature, 513(7516), 85-89. 
Butler, S. L. (2009), The effects of buoyancy on shear-induced melt bands in a compacting porous medium, Physics of the Earth and Planetary Interiors, $173(1), 51-59$.

Běhounková, M., and H. Čížková (2008), Long-wavelength character of subducted slabs in the lower mantle, Earth and Planetary Science Letters, 275 (1-2), 43-53, doi:10.1016/j.epsl.2008.07.059.

Canales, J. P., J. J. Daobeitia, R. S. Detrick, E. E. E. Hooft, R. Bartolom, and D. F. Naar (1997), Variations in axial morphology along the Galápagos spreading center and the influence of the Galápagos hotspot, Journal of Geophysical Research: Solid Earth, 102(B12), 27,341-27,354.

Cande, S. C., and D. R. Stegman (2011), Indian and African plate motions driven by the push force of the réunion plume head, Nature, 475, 47, doi: $10.1038 /$ nature10174.

Cannat, M., D. Sauter, J. Escartn, L. Lavier, and S. Picazo (2009), Oceanic corrugated surfaces and the strength of the axial lithosphere at slow spreading ridges, Earth and Planetary Science Letters, 288(1), 174-183, doi: 10.1016/j.epsl.2009.09.020.

Cannat, M., F. Fontaine, and J. Escartin (2010), Serpentinization and associated hydrogen and methane fluxes at slow spreading ridges, Diversity of hydrothermal systems on slow spreading ocean ridges, pp. 241-264, doi: 10.1029/2008GM000760.

Capitanio, F. A., and M. Faccenda (2012), Complex mantle flow around heterogeneous subducting oceanic plates, Earth and Planetary Science Letters, 353, 29-37, doi:10.1016/j.epsl.2012.07.042.

Capitanio, F. A., G. Morra, and S. Goes (2009), Dynamics of plate bending at the trench and slab-plate coupling, Geochem. Geophys. Geosyst., 10(4), Q04,002.

Carlson, R. L., and P. J. Melia (1984), Subduction hinge migration, Tectonophysics, 102(1), 399-411, doi:10.1016/0040-1951(84)90024-6.

Carlson, R. L., T. W. C. Hilde, and S. Uyeda (1983), The driving mechanism of plate tectonics: Relation to age of the lithosphere at trenches, Geophys. Res. Lett, 10(4), 297-300. 
Chemenda, A. I., J.-P. Burg, and M. Mattauer (2000), Evolutionary model of the Himalaya-Tibet system: geopoem: based on new modelling, geological and geophysical data, Earth and Planetary Science Letters, 174(3-4), 397409 .

Cherkaoui, A. S. M., W. S. D. Wilcock, R. A. Dunn, and D. R. Toomey (2003), A numerical model of hydrothermal cooling and crustal accretion at a fast spreading mid-ocean ridge, Geochemistry, Geophysics, Geosystems, $4(9)$.

Choi, E.-s., L. Lavier, and M. Gurnis (2008), Thermomechanics of mid-ocean ridge segmentation, Physics of the Earth and Planetary Interiors, 171(1), $374-386$.

Christensen, U. R. (1996), The influence of trench migration on slab penetration into the lower mantle, Earth and Planetary Science Letters, 140(1-4), 27-39.

Clift, P. D. (2017), A revised budget for Cenozoic sedimentary carbon subduction, Rev. Geophys., 55(1), 97-125, doi:10.1002/2016RG000531.

Cloos, M., and R. L. Shreve (1988), Subduction-channel model of prism accretion, melange formation, sediment subduction, and subduction erosion at convergent plate margins: 1. Background and description, pure and applied geophysics, 128(3-4), 455-500, doi:10.1007/BF00874548.

Coffin, M., and O. Eldholm (2005), Large igneous provinces, in Encyclopedia of Geology, edited by R. C. Seiley, R. Cocks, and I. R. Plimer, pp. 315-325, Elsevier, Oxford.

Colin, P., and L. Fleitout (1990), Topography of the ocean floor: Thermal evolution of the lithosphere and interaction of deep mantle heterogeneities with the lithosphere, Geophys. Res. Lett., 17(11), 1961-1964.

Coltice, N., T. Rolf, P. J. Tackley, and S. Labrosse (2012), Dynamic causes of the relation between area and age of the ocean floor, Science, 336(6079), $335-338$.

Coltice, N., M. Gérault, and M. Ulvrová (2017), A mantle convection perspective on global tectonics, Earth-Science Reviews, 165, 120-150, doi: 10.1016/j.earscirev.2016.11.006. 
Condie, K. C., and V. Pease (2008), When did plate tectonics begin on planet Earth?, vol. 440, Geological Society of America.

Conrad, C. P. (2013), The solid Earth's influence on sea level, GSA Bulletin, 125(7-8), 1027-1052, doi:10.1130/b30764.1.

Conrad, C. P., and B. H. Hager (1999), Effects of plate bending and fault strength at subduction zones on plate dynamics, Journal of Geophysical Research: Solid Earth, 104(B8), 17,551-17,571, doi: 10.1029/1999JB900149.

Conrad, C. P., and B. H. Hager (2001), Mantle convection with strong subduction zones, Geophysical Journal International, 144(2), 271-288, doi: 10.1046/j.1365-246x.2001.00321.x.

Conrad, C. P., and C. Lithgow-Bertelloni (2002), How mantle slabs drive plate tectonics, Science, 298(5591), 207-209, doi:10.1126/science.1074161.

Conrad, C. P., and C. Lithgow-Bertelloni (2004), The temporal evolution of plate driving forces: Importance of slab suction versus slab pull during the Cenozoic, J. Geophys. Res., 109(B10), doi:10.1029/2004JB002991.

Conrad, C. P., and C. Lithgow-Bertelloni (2006), Influence of continental roots and asthenosphere on plate-mantle coupling, Geophys. Res. Lett., 33(5), L05,312, doi:10.1029/2005GL025621.

Conrad, C. P., B. Steinberger, and T. H. Torsvik (2013), Stability of active mantle upwelling revealed by net characteristics of plate tectonics, Nature, 498(7455), 479, doi:10.1038/nature12203.

Crameri, F., and B. J. P. Kaus (2010), Parameters that control lithosphericscale thermal localization on terrestrial planets, Geophys. Res. Lett., 37(9), L09,308, doi:10.1029/2010GL042921.

Crameri, F., and C. Lithgow-Bertelloni (2017), Abrupt upper-plate tilting during slab-transition-zone collision, Tectonophysics, doi: 10.1016/j.tecto.2017.09.013.

Crameri, F., and P. Tackley (2014), Spontaneous development of arcuate single-sided subduction in global 3-D mantle convection models with a free surface, J. Geophys. Res. Solid Earth, 119(7), 5921-5942, doi: 10.1002/2014JB010939. 
Crameri, F., and P. Tackley (2015), Parameters controlling dynamically selfconsistent plate tectonics and single-sided subduction in global models of mantle convection, J. Geophys. Res. Solid Earth, 120(5), 3680-3706.

Crameri, F., and P. Tackley (2016), Subduction initiation from a stagnant lid and global overturn: New insights from numerical models with a free surface, Progress in Earth and Planetary Science, 3(1), 1-19, doi: 10.1186/s40645-016-0103-8.

Crameri, F., P. Tackley, I. Meilick, T. Gerya, and B. Kaus (2012), A free plate surface and weak oceanic crust produce single-sided subduction on Earth, Geophys. Res. Lett., 39(3), L03,306, doi:10.1029/2011GL050046.

Crameri, F., C. R. Lithgow-Bertelloni, and P. J. Tackley (2017), The dynamical control of subduction parameters on surface topography, Geochem. Geophys. Geosyst., 18(4), 1661-1687, doi:10.1002/2017GC006821.

Crosby, A., and D. McKenzie (2009), An analysis of young ocean depth, gravity and global residual topography, Geophysical Journal International, 178(3), 1198-1219, doi:10.1111/j.1365-246X.2009.04224.x.

Crowley, J. W., M. Gérault, and R. J. O'Connell (2011), On the relative influence of heat and water transport on planetary dynamics, Earth and Planetary Science Letters, 310(3), 380-388, doi:10.1016/j.epsl.2011.08.035.

D' Acremont, E., S. Leroy, M. Maia, P. Gente, and J. Autin (2010), Volcanism, jump and propagation on the Sheba ridge, eastern Gulf of Aden: segmentation evolution and implications for oceanic accretion processes, Geophysical Journal International, 180(2), 535-551, doi:10.1111/j.1365246x.2009.04448.x.

Dalton, C. A., C. H. Langmuir, and A. Gale (2014), Geophysical and geochemical evidence for deep temperature variations beneath mid-ocean ridges, Science, 344 (6179), 80, doi:10.1126/science.1249466.

Dantas, C., G. Ceuleneer, M. Gregoire, M. Python, R. Freydier, J. Warren, and H. J. B. Dick (2007), Pyroxenites from the Southwest Indian Ridge, 9-16 E: cumulates from incremental melt fractions produced at the top of a cold melting regime, Journal of Petrology, 48(4), 647-660. 
Dasgupta, R., and M. M. Hirschmann (2006), Melting in the Earth's deep upper mantle caused by carbon dioxide, Nature, 440(7084), 659, doi: 10.1038/nature04612.

Dasgupta, R., and M. M. Hirschmann (2010), The deep carbon cycle and melting in Earth's interior, Earth and Planetary Science Letters, 298(1), 1-13, doi:http://dx.doi.org/10.1016/j.epsl.2010.06.039.

Dasgupta, R., A. Mallik, K. Tsuno, A. C. Withers, G. Hirth, and M. M. Hirschmann (2013), Carbon-dioxide-rich silicate melt in the Earth's upper mantle, Nature, 493(7431), 211, doi:10.1038/nature11731.

Davaille, A., and C. Jaupart (1994), Onset of thermal convection in fluids with temperature-dependent viscosity: Application to the oceanic mantle, J. Geophys. Res., 99(B10), 19,853-19,866, doi:10.1029/94JB01405.

Davaille, A., S. E. Smrekar, and S. Tomlinson (2017), Experimental and observational evidence for plume-induced subduction on Venus, Nature Geosci, advance online publication, doi:10.1038/ngeo2928.

Davies, G. F. (1981), Regional compensation of subducted lithosphere: effects on geoid, gravity and topography from a preliminary model, Earth and Planetary Science Letters, 54(3), 431-441.

Davies, G. F. (1992), On the emergence of plate tectonics, Geology, 20(11), 963-966, doi:10.1130/0091-7613(1992)020<0963:OTEOPT>2.3.CO;2.

Davies, J. H., and D. R. Davies (2010), Earth's surface heat flux, Solid Earth, 1(1), 5-24, doi:10.5194/se-1-5-2010.

Davis, E. E., and C. R. B. Lister (1974), Fundamentals of ridge crest topography, Earth and Planetary Science Letters, 21(4), 405-413, doi: 10.1016/0012-821X(74)90180-0.

de Bremaecker, J.-C. (1977), Is the oceanic lithosphere elastic or viscous?, $J$. Geophys. Res., 82(14), 2001-2004.

deMartin, B. J., R. A. Sohn, J. Pablo Canales, and S. E. Humphris (2007), Kinematics and geometry of active detachment faulting beneath the TransAtlantic Geotraverse (TAG) hydrothermal field on the Mid-Atlantic Ridge, Geology, 35(8), 711, doi:10.1130/G23718A.1. 
Deschamps, F., and P. J. Tackley (2008), Searching for models of thermochemical convection that explain probabilistic tomography, Physics of the Earth and Planetary Interiors: I. Principles and influence of rheological parameters, 171 (1), 357-373, doi:10.1016/j.pepi.2008.04.016.

Deschamps, F., and P. J. Tackley (2009), Searching for models of thermochemical convection that explain probabilistic tomography. II-Influence of physical and compositional parameters, Physics of the Earth and Planetary Interiors, 176 (1), 1-18, doi:10.1016/j.pepi.2009.03.012.

Deschamps, F., J. Trampert, and P. J. Tackley (2007), Thermo-Chemical Structure of the Lower Mantle: Seismological Evidence and Consequences for Geodynamics, pp. 293-320, Springer Netherlands, Dordrecht, doi: 10.1007/978-1-4020-5750-2_11.

Detrick, R. S., A. J. Harding, G. M. Kent, J. A. Orcutt, J. C. Mutter, and P. Buhl (1993), Seismic structure of the southern East Pacific Rise, Science, 259(5094), 499-504.

Dhuime, B., A. Wuestefeld, and C. J. Hawkesworth (2015), Emergence of modern continental crust about 3 billion years ago, Nature Geosci, 8(7), 552-555, doi:10.1038/ngeo2466.

Dick, H. J. B., J. Lin, and H. Schouten (2003), An ultraslow-spreading class of ocean ridge, Nature, 426(6965), 405.

Dietz, R. S. (1961), Continent and ocean basin evolution by spreading of the sea floor, Nature, 190(4779), 854-857.

Doin, M. P., and L. Fleitout (1996), Thermal evolution of the oceanic lithosphere: an alternative view, Earth and Planetary Science Letters, 142(1), 121-136, doi:10.1016/0012-821X(96)00082-9.

Doin, M.-P., and L. Fleitout (2000), Flattening of the oceanic topography and geoid: thermal versus dynamic origin, Geophysical Journal International, 143(3), 582-594, doi:10.1046/j.1365-246x.2000.00229.x.

Domeier, M., P. V. Doubrovine, T. H. Torsvik, W. Spakman, and A. L. Bull (2016), Global correlation of lower mantle structure and past subduction, Geophys. Res. Lett., 43(10), 4945-4953, doi:10.1002/2016GL068827. 
Duarte, J., W. Schellart, and F. Rosas (2016), The future of Earth's oceans: consequences of subduction initiation in the Atlantic and implications for supercontinent formation, Geological Magazine, 17, 1-14, doi:10.1017/s0016756816000716.

Duretz, T., T. V. Gerya, and D. A. May (2011), Numerical modelling of spontaneous slab breakoff and subsequent topographic response, Tectonophysics, 502(1-2), 244-256.

Duretz, T., S. M. Schmalholz, and T. V. Gerya (2012), Dynamics of slab detachment, Geochem. Geophys. Geosyst., 13(3), Q03,020.

Dutkiewicz, A., R. D. Müller, X. Wang, S. O'Callaghan, J. Cannon, and N. M. Wright (2017), Predicting sediment thickness on vanished ocean crust since $200 \mathrm{Ma}$, Geochem. Geophys. Geosyst., 18(12), 4586-4603, doi: $10.1002 / 2017 \mathrm{GC} 007258$.

Dymkova, D., and T. Gerya (2013), Porous fluid flow enables oceanic subduction initiation on Earth, Geophys. Res. Lett., 40(21), 5671-5676.

Dziewonski, A. M., V. Lekic, and B. A. Romanowicz (2010), Mantle anchor structure: An argument for bottom up tectonics, Earth and Planetary Science Letters, 299(1), 69-79, doi:10.1016/j.epsl.2010.08.013.

Edmonds, H. N., P. J. Michael, E. T. Baker, and D. P. Connelly (2003), Discovery of abundant hydrothermal venting on the ultraslow-spreading Gakkel ridge in the Arctic Ocean, Nature, 421(6920), 252.

Eilon, Z. C., and G. A. Abers (2017), High seismic attenuation at a midocean ridge reveals the distribution of deep melt, Science Advances, 3(5), e1602,829, doi:10.1126/sciadv.1602829.

England, P. C., and R. F. Katz (2010), Melting above the anhydrous solidus controls the location of volcanic arcs, Nature, 46r(7316), 700-703, doi: 10.1038/nature09417.

Evans, R., P. Tarits, A. Chave, A. White, G. Heinson, J. Filloux, H. Toh, N. Seama, H. Utada, J. Booker, et al. (1999), Asymmetric electrical structure in the mantle beneath the East Pacific Rise at $17 \mathrm{~S}$, Science, 286(5440), 752-756, doi:10.1126/science.286.5440.752. 
Evans, R. L., G. Hirth, K. Baba, D. Forsyth, A. Chave, and R. Mackie (2005), Geophysical evidence from the MELT area for compositional controls on oceanic plates, Nature, 437(7056), 249-252.

Faak, K., and K. M. Gillis (2016), Slow cooling of the lowermost oceanic crust at the fast-spreading East Pacific Rise, Geology, 44(2), 115-118, doi: 10.1130/G37353.1.

Faccenna, C., T. W. Becker, S. Lallemand, Y. Lagabrielle, F. Funiciello, and C. Piromallo (2010), Subduction-triggered magmatic pulses: A new class of plumes?, Earth and Planetary Science Letters, 299(1), 54-68.

Faccenna, C., T. W. Becker, C. P. Conrad, and L. Husson (2013), Mountain building and mantle dynamics, Tectonics, 32(1), 80-93.

Farla, R. J., S.-i. Karato, and Z. Cai (2013), Role of orthopyroxene in rheological weakening of the lithosphere via dynamic recrystallization, Proceedings of the National Academy of Sciences, 110(41), 16,355-16,360, doi: 10.1073/pnas.1218335110.

Fenner, R. (1975), On local solutions to non-Newtonian slow viscous flows, International Journal of Non-Linear Mechanics, 10(5), 207-214.

Fisher, A., E. Davis, M. Hutnak, V. Spiess, et al. (2003), Hydrothermal recharge and discharge across $50 \mathrm{~km}$ guided by seamounts on a young ridge flank, Nature, 421(6923), 618.

Fisher, A. T., and R. P. Von Herzen (2005), Models of hydrothermal circulation within 106 Ma seafloor: Constraints on the vigor of fluid circulation and crustal properties, below the Madeira Abyssal Plain, Geochemistry, Geophysics, Geosystems, 6(11), doi:10.1029/2005GC001013.

Flament, N., M. Gurnis, and R. D. Müller (2013), A review of observations and models of dynamic topography, Lithosphere, 5(2), 189-210.

Forsyth, D., and S. Uyeda (1975), On the relative importance of the driving forces of plate motion*, Geophysical Journal of the Royal Astronomical Society, 43(1), 163-200, doi:10.1111/j.1365-246X.1975.tb00631.x.

Frank, F. C. (1968), Curvature of Island Arcs, Nature, 220(5165), 363-363. 
Fukao, Y., and M. Obayashi (2013), Subducted slabs stagnant above, penetrating through, and trapped below the $660 \mathrm{~km}$ discontinuity, J. Geophys. Res. Solid Earth, 118(11), 5920-5938.

Fukao, Y., S. Widiyantoro, and M. Obayashi (2001), Stagnant slabs in the upper and lower mantle transition region, Rev. Geophys., 39(3), 291-323.

Funiciello, F., C. Faccenna, D. Giardini, and K. Regenauer-Lieb (2003), Dynamics of retreating slabs: 2. Insights from three-dimensional laboratory experiments, J. Geophys. Res., 108(B4), 2207, doi: doi:10.1029/2001JB000896.

Funiciello, F., C. Faccenna, and D. Giardini (2004), Role of lateral mantle flow in the evolution of subduction systems: insights from laboratory experiments, Geophysical Journal International, 157(3), 1393-1406.

Gale, A., C. A. Dalton, C. H. Langmuir, Y. Su, and J.-G. Schilling (2013), The mean composition of ocean ridge basalts, Geochemistry, Geophysics, Geosystems, 14(3), 489-518, doi:10.1029/2012GC004334.

Garel, F., S. Goes, D. R. Davies, J. H. Davies, S. C. Kramer, and C. R. Wilson (2014), Interaction of subducted slabs with the mantle transition-zone: A regime diagram from $2-\mathrm{D}$ thermo-mechanical models with a mobile trench and an overriding plate, Geochem. Geophys. Geosyst., 15(5), 1739-1765, doi:10.1002/2014GC005257.

Garfunkel, Z., C. A. Anderson, and G. Schubert (1986), Mantle circulation and the lateral migration of subducted slabs, J. Geophys. Res., 91(B7), 7205-7223.

Gassmöller, R., J. Dannberg, E. Bredow, B. Steinberger, and T. H. Torsvik (2016), Major influence of plume-ridge interaction, lithosphere thickness variations, and global mantle flow on hotspot volcanism-the example of Tristan, Geochemistry, Geophysics, Geosystems, 17(4), 1454-1479, doi: 10.1002/2015GC006177.

Gente, P., J. Dyment, M. Maia, and J. Goslin (2003), Interaction between the Mid-Atlantic Ridge and the Azores hot spot during the last $85 \mathrm{Myr}$ : Emplacement and rifting of the hot spot-derived plateaus, Geochemistry, Geophysics, Geosystems, 4(10), doi:10.1029/2003GC000527. 
German, C. R., and J. Lin (2004), The Thermal Structure of the Oceanic Crust, Ridge-Spreading and Hydrothermal Circulation: How Well do we Understand their Inter-Connections?, Mid-Ocean Ridges, pp. 1-18.

German, C. R., K. Casciotti, J.-C. Dutay, L.-E. Heimbürger, W. J. Jenkins, R. A. Mills, H. Obata, R. Schlitzer, A. Tagliabue, D. R. Turner, et al. (2016), Hydrothermal impacts on trace element and isotope ocean biogeochemistry, Phil. Trans. R. Soc. A, $374(2081)$, 20160,035, doi: 10.1098/rsta.2016.0035.

Gernigon, L., A. Blischke, A. Nasuti, and M. Sand (2015), Conjugate volcanic rifted margins, seafloor spreading, and microcontinent: Insights from new high-resolution aeromagnetic surveys in the Norway Basin, Tectonics, 34(5), 907-933, doi:10.1002/2014TC003717.

Gerya, T. (2010), Introduction to numerical geodynamic modelling, Cambridge University Press.

Gerya, T. (2011), Future directions in subduction modeling, Journal of Geodynamics, 52(5), 344-378.

Gerya, T. (2012), Origin and models of oceanic transform faults, Tectonophysics, 522-523(0), 34-54.

Gerya, T. V., J. A. Connolly, and D. A. Yuen (2008), Why is terrestrial subduction one-sided?, Geology, 36(1), 43-46, doi:10.1130/G24060A.1.

Gerya, T. V., R. J. Stern, M. Baes, S. V. Sobolev, and S. A. Whattam (2015), Plate tectonics on the Earth triggered by plume-induced subduction initiation, Nature, 527(7577), 221-225.

Ghods, A., and J. Arkani-Hamed (2000), Melt migration beneath midocean ridges, Geophysical Journal International, 140(3), 687-697, doi: 10.1046/j.1365-246X.2000.00032.x.

Gillis, K. M., L. A. Coogan, and R. Pedersen (2005), Strontium isotope constraints on fluid flow in the upper oceanic crust at the East Pacific Rise, Earth and Planetary Science Letters, 232(1), 83-94.

Goes, S., R. Agrusta, J. van Hunen, and F. Garel (2017), Subductiontransition zone interaction: A review, Geosphere, 13(3), 644-664, doi: 10.1130/ges01476.1. 
Gordon, R. G. (1998), The plate tectonic approximation: Plate nonrigidity, diffuse plate boundaries, and global plate reconstructions, Annu. Rev. Earth Planet. Sci., 26(1), 615-642, doi:10.1146/annurev.earth.26.1.615.

Graham, D. W., B. B. Hanan, J. E. Lupton, K. Hoernle, R. Werner, D. M. Christie, and J. M. Sinton (2014), Helium isotope variations and mantle plume-spreading ridge interactions along the galápagos spreading center, The Galapagos: A Natural Laboratory for the Earth Sciences, Geophys. Monogr. Ser, pp. 393-414.

Grand, S. P. (2002), Mantle shear-wave tomography and the fate of subducted slabs, Philosophical Transactions of the Royal Society of London. Series A:Mathematical, Physical and Engineering Sciences, 360(1800), 2475-2491.

Gregg, P. M., M. D. Behn, J. Lin, and T. L. Grove (2009), Melt generation, crystallization, and extraction beneath segmented oceanic transform faults, Journal of Geophysical Research: Solid Earth, 114(B11), doi: 10.1029/2008JB006100.

Griffiths, R. W., R. I. Hackney, and R. D. van der Hilst (1995), A laboratory investigation of effects of trench migration on the descent of subducted slabs, Earth and Planetary Science Letters, 133(1), 1-17.

Grigné, C., S. Labrosse, and P. J. Tackley (2005), Convective heat transfer as a function of wavelength: Implications for the cooling of the Earth, $J$. Geophys. Res., 110 (B3).

Grindlay, N. R., J. A. Madsen, C. Rommevaux-Jestin, and J. Sclater (1998), A different pattern of ridge segmentation and mantle Bouguer gravity anomalies along the ultra-slow spreading Southwest Indian Ridge (15 30 E to 25 E), Earth and Planetary Science Letters, 161(1), 243-253.

Guillaume, B., M. Moroni, F. Funiciello, J. Martinod, and C. Faccenna (2010), Mantle flow and dynamic topography associated with slab window opening: Insights from laboratory models, Tectonophysics, 496(1), 83-98, doi:10.1016/j.tecto.2010.10.014.

Gurnis, M., and B. H. Hager (1988), Controls of the structure of subducted slabs, Nature, 335, 317-321, doi:10.1038/335317a0. 
Gurnis, M., C. Eloy, and S. Zhong (1996), Free-surface formulation of mantle convection-II. Implication for subduction-zone observables, Geophysical Journal International, 127(3), 719-727.

Gurnis, M., R. D. Müller, and L. Moresi (1998), Cretaceous vertical motion of Australia and the AustralianAntarctic Discordance, Science, 279 (5356), 1499-1504, doi:10.1126/science.279.5356.1499.

Gurnis, M., C. Hall, and L. Lavier (2004), Evolving force balance during incipient subduction, Geochem. Geophys. Geosyst., 5(7), Q07,001.

Hafkenscheid, E., M. J. R. Wortel, and W. Spakman (2006), Subduction history of the Tethyan region derived from seismic tomography and tectonic reconstructions, J. Geophys. Res., 111(B8), doi:10.1029/2005JB003791.

Hall, C. E., M. Gurnis, M. Sdrolias, L. L. Lavier, and R. Müller (2003), Catastrophic initiation of subduction following forced convergence across fracture zones, Earth and Planetary Science Letters, 212(1-2), 15-30.

Hansen, L. N., and J. M. Warren (2015), Quantifying the effect of pyroxene on deformation of peridotite in a natural shear zone, Journal of Geophysical Research: Solid Earth, 120(4), 2717-2738, doi:10.1002/2014JB011584.

Hansen, V. L. (2007), Subduction origin on early Earth: A hypothesis, Geology, 35(12), 1059-1062.

Haq, B. U. (2014), Cretaceous eustasy revisited, Global and Planetary Change, 113, 44-58.

Hardarson, B., J. Fitton, R. Ellam, and M. Pringle (1997), Rift relocation-a geochemical and geochronological investigation of a palaeo-rift in northwest Iceland, Earth and Planetary Science Letters, 153(3), 181-196, doi: 10.1016/S0012-821X(97)00145-3.

Harmon, N., D. W. Forsyth, and D. S. Weeraratne (2009), Thickening of young pacific lithosphere from high-resolution Rayleigh wave tomography: A test of the conductive cooling model, Earth and Planetary Science Letters, $278(1), 96-106$.

Harris, M., R. M. Coggon, M. Wood, C. E. Smith-Duque, T. J. Henstock, and D. A. Teagle (2017), Hydrothermal cooling of 
the ocean crust: Insights from ODP Hole 1256D, Earth and Planetary Science Letters, 462(Supplement C), 110 - 121, doi: https://doi.org/10.1016/j.epsl.2017.01.010.

Hart, S. R. (1993), Equilibration during mantle melting: a fractal tree model, Proceedings of the National Academy of Sciences, 90(24), 11,914-11,918.

Hasenclever, J., S. Theissen-Krah, L. H. Rüpke, J. P. Morgan, K. Iyer, S. Petersen, and C. W. Devey (2014), Hybrid shallow on-axis and deep off-axis hydrothermal circulation at fast-spreading ridges, Nature, 508(7497), 508.

Hasterok, D. (2013), A heat flow based cooling model for tectonic plates, Earth and Planetary Science Letters, 361, 34-43, doi: 10.1016/j.epsl.2012.10.036.

Hebert, L. B., and L. G. Montési (2010), Generation of permeability barriers during melt extraction at mid-ocean ridges, Geochemistry, Geophysics, Geosystems, 11(12), doi:10.1029/2010GC003270.

Hebert, L. B., and L. G. Montési (2011), Melt extraction pathways at segmented oceanic ridges: Application to the East Pacific Rise at the Siqueiros transform, Geophysical Research Letters, 38(11), doi: 10.1029/2011GL047206.

Hellebrand, E., J. E. Snow, P. Hoppe, and A. W. Hofmann (2002), Garnetfield melting and late-stage refertilization in 'residual' abyssal peridotites from the Central Indian Ridge, Journal of Petrology, 43(12), 2305-2338.

Herrendorfer, R., Y. van Dinther, T. Gerya, and L. A. Dalguer (2015), Earthquake supercycle in subduction zones controlled by the width of the seismogenic zone, Nature Geosci, 8(6), 471-474, doi:10.1038/ngeo2427.

Herzberg, C., K. Condie, and J. Korenaga (2010), Thermal history of the earth and its petrological expression, Earth and Planetary Science Letters, 292(1), 79-88.

Hess, H. H. (1962), History of ocean basins, Petrologic studies, 4, 599-620.

Heuret, A., and S. Lallemand (2005), Plate motions, slab dynamics and back-arc deformation, Thermal Structure and Dynamics of Subduction Zones: Insights from Observations and Modeling, 149(1), 31-51, doi: 10.1016/j.pepi.2004.08.022. 
Heuret, A., C. P. Conrad, F. Funiciello, S. Lallemand, and L. Sandri (2012), Relation between subduction megathrust earthquakes, trench sediment thickness and upper plate strain, Geophys. Res. Lett., 39(5), doi: 10.1029/2011GL050712.

Hewitt, I., and A. Fowler (2009), Melt channelization in ascending mantle, Journal of Geophysical Research: Solid Earth, 114(B6), doi: 10.1029/2008JB006185.

Hieronymus, C. F. (2004), Control on seafloor spreading geometries by stressand strain-induced lithospheric weakening, Earth and Planetary Science Letters, 222(1), 177-189.

Hillier, J. K. (2010), Subsidence of 'normal' seafloor: Observations do indicate 'flattening', Journal of Geophysical Research: Solid Earth, 115(B3), doi:10.1029/2008jb005994.

Hillier, J. K., and A. B. Watts (2005), Relationship between depth and age in the North Pacific Ocean, J. Geophys. Res., 110(B2), doi: 10.1029/2004JB003406.

Hirschmann, M. M. (2000), Mantle solidus: Experimental constraints and the effects of peridotite composition, Geochemistry, Geophysics, Geosystems, 1 (10), doi:10.1029/2000GC000070.

Hirth, G., and D. Kohlstedt (2003), Rheology of the upper mantle and the mantle wedge: A view from the experimentalists, in Geophys. Monogr. Ser., vol. 138, pp. 83-105, AGU, Washington, DC.

Hirth, G., and D. L. Kohlstedt (1995), Experimental constraints on the dynamics of the partially molten upper mantle: 2. Deformation in the dislocation creep regime, J. Geophys. Res., 100 (B8), 15,441-15,449, doi: 10.1029/95JB01292.

Hirth, G., and D. L. Kohlstedt (1996), Water in the oceanic upper mantle: implications for rheology, melt extraction and the evolution of the lithosphere, Earth and Planetary Science Letters, 144(12), 93-108.

Hoggard, M. J., N. White, and D. Al-Attar (2016), Global dynamic topography observations reveal limited influence of large-scale mantle flow, Nature Geosci, 9(6), 456-463, doi:10.1038/ngeo2709. 
Holmes, A. (1931), Radioactivity and earth movements, Nature, 128, 496, doi:10.1038/128496e0.

Holmes, R. C., M. Tolstoy, J. R. Cochran, and J. S. Floyd (2008), Crustal thickness variations along the Southeast Indian Ridge (100-116 E) from 2D body wave tomography, Geochemistry, Geophysics, Geosystems, 9(12), doi:10.1029/2008GC002152.

Holt, A. F., and T. W. Becker (2017), The effect of a power-law mantle viscosity on trench retreat rate, Geophysical Journal International, 208(1), 491-507, doi:10.1093/gji/ggw392.

Holtzman, B., D. Kohlstedt, M. Zimmerman, F. Heidelbach, T. Hiraga, and J. Hustoft (2003), Melt segregation and strain partitioning: implications for seismic anisotropy and mantle flow, Science, 301(5637), 1227-1230, doi:10.1126/science.1087132.

Howell, S. M., G. Ito, A. J. Breivik, A. Rai, R. Mjelde, B. Hanan, K. Sayit, and P. Vogt (2014), The origin of the asymmetry in the iceland hotspot along the Mid-Atlantic Ridge from continental breakup to present-day, Earth and Planetary Science Letters, 392, 143-153, doi: 10.1016/j.epsl.2014.02.020.

Huang, J., S. Zhong, and J. van Hunen (2003), Controls on sublithospheric small-scale convection, J. Geophys. Res., 108(B8), doi: 10.1029/2003JB002456.

Humphris, S. E., R. A. Zierenberg, L. S. Mullineaux, and R. E. Thomson (1995), Seafloor hydrothermal systems, Physical, chemical, biological, and geological interactions. American Geophysical Union, Washington DC. USA.

Hutnak, M., A. Fisher, L. Zühlsdorff, V. Spiess, P. Stauffer, and C. Gable (2006), Hydrothermal recharge and discharge guided by basement outcrops on 0.7-3.6 Ma seafloor east of the Juan de Fuca Ridge: Observations and numerical models, Geochemistry, Geophysics, Geosystems, 7(7).

Isacks, B., and P. Molnar (1971), Distribution of stresses in the descending lithosphere from a global survey of focal-mechanism solutions of mantle earthquakes, Rev. Geophys., 9(1), 103-174. 
Ishii, M., and J. Tromp (1999), Normal-mode and free-air gravity constraints on lateral variations in velocity and density of earth's mantle, Science, 285(5431), 1231, doi:10.1126/science.285.5431.1231.

Ito, G., J. Lin, and C. W. Gable (1997), Interaction of mantle plumes and migrating mid-ocean ridges: Implications for the Galápagos plume-ridge system, Journal of Geophysical Research: Solid Earth, 102(B7), 15,40315,417, doi:10.1029/97JB01049.

Ito, G., J. Lin, and D. Graham (2003), Observational and theoretical studies of the dynamics of mantle plume-mid-ocean ridge interaction, Reviews of Geophysics, 41(4), doi:10.1029/2002RG000117.

Iyer, K., L. H. Rüpke, and J. P. Morgan (2010), Feedbacks between mantle hydration and hydrothermal convection at ocean spreading centers, Earth and Planetary Science Letters, 296(1), 34-44.

Jadamec, M. A. (2016), Insights on slab-driven mantle flow from advances in three-dimensional modelling, 200 years of geodynamic modelling, 100, 51-70, doi:10.1016/j.jog.2016.07.004.

Jadamec, M. A., and M. I. Billen (2010), Reconciling surface plate motions with rapid three-dimensional mantle flow around a slab edge, Nature, 465(7296), 338-341.

Jarrard, R. D. (1986), Relations among subduction parameters, Rev. Geophys., $24(2), 217-284$.

Jaupart, C., S. Labrosse, F. Lucazeau, and J. C. Mareschal (2015), Treatise on Geophysics, 2nd edition, chap. 7.06-Temperatures, heat and energy in the mantle of the earth, pp. 223-270, Oxford: Elsevier, doi:10.1016/B9780-444-53802-4.00126-3.

Jellinek, A. M., H. M. Gonnermann, and M. A. Richards (2003), Plume capture by divergent plate motions: implications for the distribution of hotspots, geochemistry of mid-ocean ridge basalts, and estimates of the heat flux at the core-mantle boundary, Earth and Planetary Science Letters, $205(3), 361-378$. 
Johnson, K., and H. J. Dick (1992), Open system melting and temporal and spatial variation of peridotite and basalt at the Atlantis II fracture zone, Journal of Geophysical Research: Solid Earth, 97(B6), 9219-9241.

Kameyama, M., D. A. Yuen, and S.-I. Karato (1999), Thermal-mechanical effects of low-temperature plasticity (the Peierls mechanism) on the deformation of a viscoelastic shear zone, Earth and Planetary Science Letters, 168(1), 159-172, doi:10.1016/S0012-821X(99)00040-0.

Karato, S.-i., and H. Jung (1998), Water, partial melting and the origin of the seismic low velocity and high attenuation zone in the upper mantle, Earth and Planetary Science Letters, 157(3), 193-207.

Karato, S.-I., M. Toriumi, and T. Fujii (1980), Dynamic recrystallization of olivine single crystals during high-temperature creep, Geophysical Research Letters, 7(9), 649-652.

Karato, S.-I., M. S. Paterson, and J. D. FitzGerald (1986), Rheology of synthetic olivine aggregates: Influence of grain size and water, J. Geophys. Res., 91 (B8), 8151-8176.

Karig, D. E. (1971), Origin and development of marginal basins in the western Pacific, J. Geophys. Res., 76(11), 2542-2561.

Karson, J. A., G. Früh-Green, D. S. Kelley, E. Williams, D. R. Yoerger, and M. Jakuba (2006), Detachment shear zone of the Atlantis Massif core complex, Mid-Atlantic Ridge, 30 N, Geochemistry, Geophysics, Geosystems, 7(6), doi:10.1029/2005GC001109, 2006.

Katz, R. F. (2008), Magma dynamics with the enthalpy method: Benchmark solutions and magmatic focusing at mid-ocean ridges, Journal of Petrology, 49(12), 2099-2121, doi:10.1093/petrology/egn058.

Katz, R. F., M. Spiegelman, and C. H. Langmuir (2003), A new parameterization of hydrous mantle melting, Geochemistry, Geophysics, Geosystems, 4 (9), doi:10.1029/2002GC000433.

Katz, R. F., R. Ragnarsson, and E. Bodenschatz (2005), Tectonic microplates in a wax model of sea-floor spreading, New Journal of Physics, 7(1), 37, doi:10.1088/1367-2630/7/1/037. 
Katz, R. F., M. Spiegelman, and B. Holtzman (2006), The dynamics of melt and shear localization in partially molten aggregates, Nature, 442(7103), 676.

Kaus, B. J., H. Mühlhaus, and D. A. May (2010), A stabilization algorithm for geodynamic numerical simulations with a free surface, Physics of the Earth and Planetary Interiors, 181(1-2), 12-20, doi: 10.1016/j.pepi.2010.04.007.

Kelemen, P., G. Hirth, N. Shimizu, M. Spiegelman, and H. Dick (1997), A review of melt migration processes in the adiabatically upwelling mantle beneath oceanic spreading ridges, Philosophical Transactions of the Royal Society of London A: Mathematical, Physical and Engineering Sciences, 355(1723), 283-318, doi:10.1098/rsta.1997.0010.

Kelemen, P. B., and E. Aharonov (1998), Periodic formation of magma fractures and generation of layered gabbros in the lower crust beneath oceanic spreading ridges, Faulting and magmatism at mid-ocean ridges, pp. 267289, doi:10.1029/GM106p0267.

Kelemen, P. B., N. Shimizu, and V. J. Salters (1995), Extraction of midocean-ridge basalt from the upwelling mantle by focused flow of melt in dunite channels, Nature, 375(6534), 747-753, doi:10.1038/375747a0.

Keller, T., and R. F. Katz (2016), The role of volatiles in reactive melt transport in the asthenosphere, Journal of Petrology, 57(6), 1073-1108, doi:10.1093/petrology/egw030.

Keller, T., R. F. Katz, and M. M. Hirschmann (2017), Volatiles beneath mid-ocean ridges: Deep melting, channelised transport, focusing, and metasomatism, Earth and Planetary Science Letters, 464, 55-68, doi: 10.1016/j.epsl.2017.02.006.

Kelley, D. S., J. A. Karson, D. K. Blackman, G. L. Fruh-Green, et al. (2001), An off-axis hydrothermal vent field near the Mid-Atlantic Ridge at 30 degrees N, Nature, 412(6843), 145.

Kennett, B. L. N., S. Widiyantoro, and R. D. van der Hilst (1998), Joint seismic tomography for bulk sound and shear wave speed in the Earth's mantle, J. Geophys. Res., 103(B6), 12,469-12,493, doi:10.1029/98JB00150. 
Key, K., S. Constable, L. Liu, and A. Pommier (2013), Electrical image of passive mantle upwelling beneath the northern East Pacific Rise, Nature, $495(7442), 499$.

Kincaid, C., and P. Olson (1987), An experimental study of subduction and slab migration, J. Geophys. Res., 92(B13), 13,832-13,840.

King, S. D., and B. H. Hager (1990), The relationship between plate velocity and trench viscosity in Newtonian and power-law subduction calculations, Geophysical Research Letters, 17(13), 2409-2412.

Kinzler, R. J., and T. L. Grove (1992), Primary magmas of mid-ocean ridge basalts 1. Experiments and methods, Journal of Geophysical Research: Solid Earth, 97(B5), 6885-6906, doi:10.1029/91JB02840.

Király, A., F. A. Capitanio, F. Funiciello, and C. Faccenna (2016), Subduction zone interaction: Controls on arcuate belts, Geology, 44(9), 715-718, doi:10.1130/g37912.1.

Király, A., F. A. Capitanio, F. Funiciello, and C. Faccenna (2017), Subduction induced mantle flow: Length-scales and orientation of the toroidal cell, Earth and Planetary Science Letters, 479, 284-297, doi: 10.1016/j.epsl.2017.09.017.

Klein, E. M., and C. H. Langmuir (1987), Global correlations of ocean ridge basalt chemistry with axial depth and crustal thickness, J. Geophys. Res., 92(B8), 8089-8115, doi:10.1029/JB092iB08p0808.

Klein, E. M., C. H. Langmuir, and H. Staudigel (1991), Geochemistry of basalts from the Southeast Indian Ridge, 115 E-138 E, Journal of Geophysical Research: Solid Earth, 96(B2), 2089-2107, doi:10.1029/90JB01384.

Kneller, E. A., and P. E. van Keken (2007), Trench-parallel flow and seismic anisotropy in the Mariana and Andean subduction systems, Nature, $450(7173), 1222-1225$.

Kneller, E. A., P. E. van Keken, S.-i. Karato, and J. Park (2005), B-type olivine fabric in the mantle wedge: Insights from high-resolution nonNewtonian subduction zone models, Earth and Planetary Science Letters, 237(3), 781-797, doi:10.1016/j.epsl.2005.06.049. 
Kohlstedt, D. L., and B. K. Holtzman (2009), Shearing melt out of the Earth: An experimentalist's perspective on the influence of deformation on melt extraction, Annual Review of Earth and Planetary Sciences, 37, 561-593, doi:10.1146/annurev.earth.031208.100104.

Kohlstedt, D. L., B. Evans, and S. J. Mackwell (1995), Strength of the lithosphere: Constraints imposed by laboratory experiments, J. Geophys. Res., 100 (B9), 17,587-17,602.

Kominz, M. A. (1984), Oceanic ridge volumes and sea-level change-an error analysis, chap. Interregional Unconformities and Hydrocarbon Accumulation, pp. 109-127, AAPG Special Volumes.

Korenaga, J. (2006), Archean geodynamics and the thermal evolution of Earth, Archean geodynamics and environments, pp. 7-32.

Korenaga, J. (2011), Thermal evolution with a hydrating mantle and the initiation of plate tectonics in the early Earth, J. Geophys. Res., 116(B12), doi:10.1029/2011JB008410.

Korenaga, T., and J. Korenaga (2008), Subsidence of normal oceanic lithosphere, apparent thermal expansivity, and seafloor flattening, Earth and Planetary Science Letters, 268(1), 41-51, doi:10.1016/j.epsl.2007.12.022.

Korenaga, T., and J. Korenaga (2016), Evolution of young oceanic lithosphere and the meaning of seafloor subsidence rate, J. Geophys. Res. Solid Earth, 121 (9), 6315-6332, doi:10.1002/2016JB013395.

Kump, L. R. (2008), The role of seafloor hydrothermal systems in the evolution of seawater composition during the Phanerozoic, Magma to microbe, pp. 275-283.

Lachenbruch, A. H. (1976), Dynamics of a passive spreading center, Journal of Geophysical Research, 81(11), 1883-1902.

Lallemand, S., A. Heuret, and D. Boutelier (2005), On the relationships between slab dip, back-arc stress, upper plate absolute motion, and crustal nature in subduction zones, Geochem. Geophys. Geosyst., 6(9), Q09,006, doi:10.1029/2005GC000917. 
Langmuir, C. H., E. M. Klein, and T. Plank (1993), Petrological systematics of mid-ocean ridge basalts: Constraints on melt generation beneath ocean ridges, Mantle flow and melt generation at mid-ocean ridges, pp. 183-280.

Lassiter, J., B. Byerly, J. Snow, and E. Hellebrand (2014), Constraints from Os-isotope variations on the origin of Lena Trough abyssal peridotites and implications for the composition and evolution of the depleted upper mantle, Earth and Planetary Science Letters, 403, 178-187.

Lay, T., J. Hernlund, and B. A. Buffett (2008), Core-mantle boundary heat flow, Nature Geosci, 1(1), 25-32, doi:10.1038/ngeo.2007.44.

Le Roux, V., J.-L. Bodinier, A. Tommasi, O. Alard, J.-M. Dautria, A. Vauchez, and A. Riches (2007), The Lherz spinel lherzolite: refertilized rather than pristine mantle, Earth and Planetary Science Letters, 259(3), 599-612.

Leat, P. T., and R. D. Larter (2003), Intra-oceanic subduction systems: introduction, Geological Society, London, Special Publications, 219(1), 1, doi:10.1144/GSL.SP.2003.219.01.01.

Lee, C., and S. D. King (2011), Dynamic buckling of subducting slabs reconciles geological and geophysical observations, Earth and Planetary Science Letters, 312(3-4), 360-370, doi:10.1016/j.epsl.2011.10.033.

Lenardic, A., and W. M. Kaula (1994), Self-lubricated mantle convection: Two-dimensional models, Geophys. Res. Lett., 21(16), 1707-1710.

Lenardic, A., and W. M. Kaula (1996), Near-surface thermal/chemical boundary layer convection at infinite Prandtl number: two-dimensional numerical experiments, Geophysical Journal International, 126(3), 689711, doi:10.1111/j.1365-246X.1996.tb04698.x.

Leroy, S., F. Lucazeau, E. d'Acremont, L. Watremez, J. Autin, S. Rouzo, N. Bellahsen, C. Tiberi, C. Ebinger, M.-O. Beslier, et al. (2010), Contrasted styles of rifting in the eastern Gulf of Aden: a combined wide-angle, multichannel seismic, and heat flow survey, Geochemistry, Geophysics, Geosystems, $11(7)$. 
Li, C., R. D. van der Hilst, E. R. Engdahl, and S. Burdick (2008), A new global model for P wave speed variations in Earth's mantle, Geochem. Geophys. Geosyst., 9(5), doi:10.1029/2007GC001806.

Li, X.-D., and B. Romanowicz (1996), Global mantle shear velocity model developed using nonlinear asymptotic coupling theory, J. Geophys. Res., 101 (B10), 22,245-22,272.

Li, Z.-H., and N. M. Ribe (2012), Dynamics of free subduction from 3-D boundary element modeling, J. Geophys. Res., 117(B6), B06,408.

Ligi, M., E. Bonatti, L. Gasperini, and A. N. Poliakov (2002), Oceanic broad multifault transform plate boundaries, Geology, 30(1), 11-14.

Lin, J., and J. P. Morgan (1992), The spreading rate dependence of threedimensional mid-ocean ridge gravity structure, Geophysical Research Letters, 19(1), 13-16, doi:10.1029/91GL03041.

Lin, J., G. Purdy, H. Schouten, J. Sempere, and C. Zervas (1990), Evidence from gravity data for focused magmatic accretion along the Mid-Atlantic Ridge, Nature, 344(6267), 627-632.

Lithgow-Bertelloni, C., and P. G. Silver (1998), Dynamic topography, plate driving forces and the African superswell, Nature, 395 (6699), 269-272.

Liu, L., S. Spasojević, and M. Gurnis (2008), Reconstructing Farallon plate subduction beneath North America back to the Late Cretaceous, Science, 322(5903), 934-938.

Lizarralde, D., J. B. Gaherty, J. A. Collins, G. Hirth, and S. D. Kim (2004), Spreading-rate dependence of melt extraction at mid-ocean ridges from mantle seismic refraction data, Nature, 432(7018), 744, doi: 10.1038/nature03140.

Lizarralde, D., G. J. Axen, H. E. Brown, J. M. Fletcher, A. GonzálezFernández, A. J. Harding, W. S. Holbrook, G. M. Kent, P. Paramo, F. Sutherland, et al. (2007), Variation in styles of rifting in the Gulf of California, Nature, 448(7152), 466, doi:10.1038/nature06035. 
Loiselet, C., J. Braun, L. Husson, C. Le Carlier de Veslud, C. Thieulot, P. Yamato, and D. Grujic (2010), Subducting slabs: Jellyfishes in the Earth's mantle, Geochem. Geophys. Geosyst., 11(8), doi: 10.1029/2010GC003172.

Long, M. D., and P. G. Silver (2008), The subduction zone flow field from seismic anisotropy: A global view, Science, 319(5861), 315-318.

Long, M. D., and P. G. Silver (2009), Mantle flow in subduction systems: The subslab flow field and implications for mantle dynamics, J. Geophys. Res., 114(B10), B10,312.

Longhi, J. (2002), Some phase equilibrium systematics of lherzolite melting: I, Geochemistry, Geophysics, Geosystems, 3(3), 1-33, doi: 10.1029/2001GC000204.

Lowell, R. P., J. S. Seewald, A. Metaxas, and M. R. Perfit (2008), Magma to microbe: modeling hydrothermal processes at oceanic spreading centers, vol. 178, John Wiley \& Sons.

Loyd, S. J., T. W. Becker, C. P. Conrad, C. Lithgow-Bertelloni, and F. A. Corsetti (2007), Time variability in Cenozoic reconstructions of mantle heat flow: Plate tectonic cycles and implications for Earth's thermal evolution, Proceedings of the National Academy of Sciences, $104(36), 14,266-$ 14,271, doi:10.1073/pnas.0706667104.

Lu, G., B. J. Kaus, L. Zhao, and T. Zheng (2015), Self-consistent subduction initiation induced by mantle flow, Terra Nova, 27, 130-138.

Lynner, C., M. L. Anderson, D. E. Portner, S. L. Beck, and H. Gilbert (2017), Mantle flow through a tear in the Nazca slab inferred from shear wave splitting, Geophys. Res. Lett., 44(13), 6735-6742, doi:10.1002/2017GL074312.

Macdonald, K. C. (1998), Linkages between faulting, volcanism, hydrothermal activity and segmentation on fast spreading centers, Faulting and magmatism at mid-ocean ridges, pp. 27-58.

Macdonald, K. C., P. Fox, L. Perram, M. Eisen, R. Haymon, S. Miller, S. M. Carbotte, M.-H. Cormier, and A. Shor (1988), A new view of the mid-ocean ridge from the behaviour of ridge-axis discontinuities, Nature, 335(6187), 217-225. 
Magde, L. S., D. W. Sparks, and R. S. Detrick (1997), The relationship between buoyant mantle flow, melt migration, and gravity bull's eyes at the Mid-Atlantic Ridge between $33 \mathrm{~N}$ and $35 \mathrm{~N}$, Earth and Planetary Science Letters, 148(1-2), 59-67.

Magni, V., C. Faccenna, J. van Hunen, and F. Funiciello (2014), How collision triggers backarc extension: Insight into Mediterranean style of extension from 3-D numerical models, Geology, 42(6), 511-514, doi: $10.1130 / \mathrm{g} 35446.1$.

Marsh, B. D. (1979), Island arc development: Some observations, experiments, and speculations, The Journal of Geology, 87(6), 687-713, doi: $10.1086 / 628460$.

Marty, J. C., and A. Cazenave (1989), Regional variations in subsidence rate of oceanic plates: a global analysis, Earth and Planetary Science Letters, 94 (3), 301-315, doi:10.1016/0012-821X(89)90148-9.

Maruyama, S., J. G. Liou, and M. Terabayashi (1996), Blueschists and Eclogites of the World and their exhumation, International Geology Review, 38 (6), 485-594, doi:10.1080/00206819709465347.

Mason, R. G. (1958), A magnetic survey off the west coast of the United States between $32 \circ \mathrm{N}$ latitude and $42 \circ \mathrm{N}$ latitude, Geophysical Journal of the Royal Astronomical Society, 1(4), 320.

McCollom, T. M., and E. L. Shock (1998), Fluid-rock interactions in the lower oceanic crust: Thermodynamic models of hydrothermal alteration, Journal of Geophysical Research: Solid Earth, 103(B1), 547-575.

McKenzie, D., and M. Bickle (1988), The volume and composition of melt generated by extension of the lithosphere, Journal of petrology, 29(3), 625679 .

McKenzie, D., J. Jackson, and K. Priestley (2005), Thermal structure of oceanic and continental lithosphere, Earth and Planetary Science Letters, 233(3), 337-349, doi:10.1016/j.epsl.2005.02.005.

McKenzie, D. P. (1969), Speculations on the consequences and causes of plate motions, Geophysical Journal International, 18(1), 1-32. 
McNamara, A. K., and S. Zhong (2004), Thermochemical structures within a spherical mantle: Superplumes or piles?, J. Geophys. Res., 109(B7), doi:10.1029/2003JB002847.

McNamara, A. K., and S. Zhong (2005), Thermochemical structures beneath Africa and the Pacific Ocean, Nature, 437(7062), 1136.

Michael, P., C. Langmuir, H. Dick, J. Snow, et al. (2003), Magmatic and amagmatic seafloor generation at the ultraslow-spreading Gakkel Ridge, Arctic Ocean, Nature, 423(6943), 956.

Miller, K. J., W.-l. Zhu, L. G. Montési, and G. A. Gaetani (2014), Experimental quantification of permeability of partially molten mantle rock, Earth and Planetary Science Letters, 388, 273-282.

Mittelstaedt, E., G. Ito, and J. van Hunen (2011), Repeat ridge jumps associated with plume-ridge interaction, melt transport, and ridge migration, Journal of Geophysical Research: Solid Earth, 116(B1), doi: 10.1029/2010JB007504.

Mittelstaedt, E., S. Soule, K. Harpp, D. Fornari, C. McKee, M. Tivey, D. Geist, M. D. Kurz, C. Sinton, and C. Mello (2012), Multiple expressions of plume-ridge interaction in the Galápagos: Volcanic lineaments and ridge jumps, Geochemistry, Geophysics, Geosystems, 13(5), doi:10.1029/2012GC004093.

Molnar, P., and T. Atwater (1978), Interarc spreading and Cordilleran tectonics as alternates related to the age of subducted oceanic lithosphere, Earth and Planetary Science Letters, 41(3), 330-340.

Montési, L. G., and M. D. Behn (2007), Mantle flow and melting underneath oblique and ultraslow mid-ocean ridges, Geophysical Research Letters, 34 (24), doi:10.1029/2007GL031067.

Montési, L. G., M. D. Behn, L. B. Hebert, J. Lin, and J. L. Barry (2011), Controls on melt migration and extraction at the ultraslow Southwest Indian Ridge 10-16 E, Journal of Geophysical Research: Solid Earth, 116(B10), doi:10.1029/2011JB008259.

Moresi, L., and V. Solomatov (1998), Mantle convection with a brittle lithosphere: thoughts on the global tectonic styles of the Earth and Venus, 
Geophysical Journal International, 133(3), 669-682, doi:10.1046/j.1365246X.1998.00521.x.

Moresi, L., and V. S. Solomatov (1995), Numerical investigation of 2D convection with extremely large viscosity variations, Physics of Fluids, 7(9), 2154-2162, doi:http://dx.doi.org/10.1063/1.868465.

Morgan, J. P. (1987), Melt migration beneath mid-ocean spreading centers, Geophysical Research Letters, 14(12), 1238-1241.

Morgan, J. P., and Y. J. Chen (1993), The genesis of oceanic crust: Magma injection, hydrothermal circulation, and crustal flow, Journal of Geophysical Research: Solid Earth, 98(B4), 6283-6297, doi:10.1029/92JB02650.

Morgan, J. P., and D. W. Forsyth (1988), Three-dimensional flow and temperature perturbations due to a transform offset: Effects on oceanic crustal and upper mantle structure, Journal of Geophysical Research: Solid Earth, 93(B4), 2955-2966.

Morgan, J. P., and E. Parmentier (1984), Lithospheric stress near a ridgetransform intersection, Geophysical Research Letters, 11(2), 113-116.

Morra, G., K. Regenauer-Lieb, and D. Giardini (2006), Curvature of oceanic arcs, Geology, 34(10), 877-880, doi:10.1130/G22462.1.

Müller, R. D., and W. R. Roest (1992), Fracture zones in the North Atlantic from combined Geosat and Seasat data, Journal of Geophysical Research: Solid Earth, 97(B3), 3337-3350, doi:10.1029/91JB02605.

Müller, R. D., W. R. Roest, and J.-Y. Royer (1998), Asymmetric sea-floor spreading caused by ridge-plume interactions, Nature, 396(6710), 455, doi: Asymmetric seafloor spreading expresses ridge-plume interactions.

Müller, R. D., C. Gaina, W. R. Roest, and D. L. Hansen (2001), A recipe for microcontinent formation, Geology, 29(3), 203-206, doi:10.1130/00917613(2001)029;0203:ARFMF ¿2.0.CO;2.

Müller, R. D., M. Sdrolias, C. Gaina, and W. R. Roest (2008), Age, spreading rates, and spreading asymmetry of the world's ocean crust, Geochemistry, Geophysics, Geosystems, 9(4), doi:10.1029/2007GC001743. 
Müller, R. D., M. Sdrolias, C. Gaina, B. Steinberger, and C. Heine (2008), Long-term sea-level fluctuations driven by ocean basin dynamics, Science, 319 (5868), 1357, doi:10.1126/science.1151540.

Müller, R. D., M. Seton, S. Zahirovic, S. E. Williams, K. J. Matthews, N. M. Wright, G. E. Shephard, K. T. Maloney, N. Barnett-Moore, M. Hosseinpour, D. J. Bower, and J. Cannon (2016), Ocean basin evolution and global-scale plate reorganization events since Pangea breakup, Annu. Rev. Earth Planet. Sci., 44(1), 107-138, doi:10.1146/annurev-earth-060115012211.

Müntener, O., G. Manatschal, L. Desmurs, and T. Pettke (2009), Plagioclase peridotites in ocean-continent transitions: refertilized mantle domains generated by melt stagnation in the shallow mantle lithosphere, Journal of Petrology, 51(1-2), 255-294.

Nair, R., and T. Chacko (2008), Role of oceanic plateaus in the initiation of subduction and origin of continental crust, Geology, 36(7), 583-586.

Nakakuki, T., M. Tagawa, and Y. Iwase (2010), Dynamical mechanisms controlling formation and avalanche of a stagnant slab, Physics of the Earth and Planetary Interiors, 183(1), 309-320, doi:10.1016/j.pepi.2010.02.003.

Nakanishi, M., and J. Hashimoto (2011), A precise bathymetric map of the world's deepest seafloor, Challenger Deep in the Mariana Trench, Marine Geophysical Research, 32(4), 455-463, doi:10.1007/s11001-011-9134-0.

Nataf, H., and F. Richter (1982), Convection experiments in fluids with highly temperature-dependent viscosity and the thermal evolution of the planets, Physics of the Earth and Planetary Interiors, 29(3-4), 320-329.

Nemcok, M., L. Pospisil, J. Lexa, and R. Donelick (1998), Tertiary subduction and slab break-off model of the Carpathian-Pannonian regions, Tectonophysics, 295(3-4), 307-340.

Ni, S., E. Tan, M. Gurnis, and D. Helmberger (2002), Sharp sides to the African Superplume, Science, 296(5574), 1850, doi: 10.1126/science.1070698.

Nicolas, A., D. Mainprice, and F. Boudier (2003), High-temperature seawater circulation throughout crust of oceanic ridges: A model derived from the 
oman ophiolites, Journal of Geophysical Research: Solid Earth, 108(B8), doi:10.1029/2002JB002094.

Nikolaeva, K., T. V. Gerya, and F. O. Marques (2010), Subduction initiation at passive margins: Numerical modeling, J. Geophys. Res., 115(B3), B03,406.

Niu, Y., and R. Batiza (1991), An empirical method for calculating melt compositions produced beneath mid-ocean ridges: Application for axis and off-axis (seamounts) melting, Journal of Geophysical Research: Solid Earth, 96 (B13), 21,753-21,777, doi:10.1029/91JB01933.

Niu, Y., M. J. O'Hara, and J. A. Pearce (2003), Initiation of subduction zones as a consequence of lateral compositional buoyancy contrast within the lithosphere: a petrological perspective, Journal of Petrology, 44(5), 851-866.

Oldenburg, D. W., and J. N. Brune (1972), Ridge transform fault spreading pattern in freezing wax, Science, 178(4058), 301-304.

Paczkowski, K., L. G. J. Montési, M. D. Long, and C. J. Thissen (2014), Three-dimensional flow in the subslab mantle, Geochem. Geophys. Geosyst., 15(10), 3989-4008, doi:10.1002/2014GC005441.

Parson, L., J. A. Pearce, B. Murton, and R. Hodkinson (1990), Role of ridge jumps and ridge propagation in the tectonic evolution of the Lau backarc basin, southwest Pacific, Geology, 18(5), 470-473, doi:10.1130/00917613(1990)018;0470:RORJAR ¿2.3.CO;2.

Parsons, B. (1981), The rates of plate creation and consumption, Geophysical Journal International, 67(2), 437-448, doi:10.1111/j.1365246X.1981.tb02759.x.

Parsons, B., and J. G. Sclater (1977), An analysis of the variation of ocean floor bathymetry and heat flow with age, J. Geophys. Res., 82(5), 803-827, doi:10.1029/JB082i005p00803.

Pedersen, R. B., I. H. Thorseth, T. E. Nygård, M. D. Lilley, and D. S. Kelley (2010), Hydrothermal activity at the arctic mid-ocean ridges, Diversity of Hydrothermal Systems on Slow Spreading Ocean Ridges, pp. 67-89, doi: 10.1029/2008GM000783. 
Piromallo, C., T. W. Becker, F. Funiciello, and C. Faccenna (2006), Threedimensional instantaneous mantle flow induced by subduction, Geophys. Res. Lett., 33(8), doi:10.1029/2005GL025390.

Püthe, C., and T. Gerya (2014), Dependence of mid-ocean ridge morphology on spreading rate in numerical 3-D models, Gondwana Research, 25(1), 270-283.

Putirka, K. D., M. Perfit, F. Ryerson, and M. G. Jackson (2007), Ambient and excess mantle temperatures, olivine thermometry, and active vs. passive upwelling, Chemical Geology, 241(3), 177-206.

Pysklywec, R. N., J. X. Mitrovica, and M. Ishii (2003), Mantle avalanche as a driving force for tectonic reorganization in the southwest Pacific, Earth and Planetary Science Letters, 209(1-2), 29-38, doi:10.1016/S0012821X(03)00073-6.

Ratcliff, J. T., P. J. Tackley, G. Schubert, and A. Zebib (1997), Transitions in thermal convection with strongly variable viscosity, Physics of the Earth and Planetary Interiors, 102(3-4), 201-212.

Regard, V., C. Faccenna, J. Martinod, and O. Bellier (2005), Slab pull and indentation tectonics: insights from 3D laboratory experiments, Physics of the Earth and Planetary Interiors, 149(1-2), 99-113.

Regenauer-Lieb, K. (1998), Dilatant plasticity applied to Alpine collision: ductile void growth in the intraplate area beneath the Eifel volcanic field, Journal of Geodynamics, 27(1), 1-21.

Regenauer-Lieb, K., D. A. Yuen, and J. Branlund (2001), The initiation of subduction: Criticality by addition of water?, Science, 294(5542), 578580, doi:10.1126/science.1063891.

Reid, I., and H. Jackson (1981), Oceanic spreading rate and crustal thickness, Marine Geophysical Researches, 5(2), 165-172.

Rey, P. F., N. Coltice, and N. Flament (2014), Spreading continents kickstarted plate tectonics, Nature, 513, 405, doi:10.1038/nature13728.

Ribe, N. (1996), The dynamics of plume-ridge interaction: 2. Off-ridge plumes, Journal of Geophysical Research: Solid Earth, 101(B7), 16,19516,204, doi:10.1029/96JB01187. 
Ribe, N. M. (2010), Bending mechanics and mode selection in free subduction: a thin-sheet analysis, Geophysical Journal International, 180(2), $559-576$.

Ribe, N. M., E. Stutzmann, Y. Ren, and R. van der Hilst (2007), Buckling instabilities of subducted lithosphere beneath the transition zone, Earth and Planetary Science Letters, 254(1-2), 173-179, doi: 10.1016/j.epsl.2006.11.028.

Ricciardi, K., and D. Abbott (1996), Increased mantle convection during the mid-Cretaceous: A comparative study of mantle potential temperature, $J$. Geophys. Res., 101(B4), 8673-8684, doi:10.1029/95JB02331.

Richard, G., D. Bercovici, and S.-I. Karato (2006), Slab dehydration in the earth's mantle transition zone, Earth and Planetary Science Letters, 251(1), 156-167, doi:10.1016/j.epsl.2006.09.006.

Richards, M. A., W.-S. Yang, J. R. Baumgardner, and H.-P. Bunge (2001), Role of a low-viscosity zone in stabilizing plate tectonics: Implications for comparative terrestrial planetology, Geochem. Geophys. Geosyst., 2(8), 1026, doi:10.1029/2000GC000115.

Richter, F. M. (1979), Focal mechanisms and seismic energy release of deep and intermediate earthquakes in the Tonga-Kermadec Region and their bearing on the depth extent of mantle flow, J. Geophys. Res., 84(B12), 6783-6795, doi:10.1029/JB084iB12p06783.

Ringwood, A. E., and D. H. Green (1966), An experimental investigation of the Gabbro-Eclogite transformation and some geophysical implications, Tectonophysics, 3(5), 383-427, doi:10.1016/0040-1951(66)90009-6.

Ritsema, J., A. Deuss, H. J. van Heijst, and J. H. Woodhouse (2011), S40RTS: a degree-40 shear-velocity model for the mantle from new Rayleigh wave dispersion, teleseismic traveltime and normal-mode splitting function measurements, Geophysical Journal International, 184(3), 1223-1236, doi:10.1111/j.1365-246x.2010.04884.x.

Roland, E., M. D. Behn, and G. Hirth (2010), Thermal-mechanical behavior of oceanic transform faults: Implications for the spatial distribution of seismicity, Geochemistry, Geophysics, Geosystems, 11(7), doi: 10.1029/2010GC003034. 
Rolf, T., and P. J. Tackley (2011), Focussing of stress by continents in 3D spherical mantle convection with self-consistent plate tectonics, Geophys. Res. Lett., 38(18), L18,301, doi:10.1029/2011GL048677.

Rondenay, S., L. G. J. Montési, and G. A. Abers (2010), New geophysical insight into the origin of the Denali volcanic gap, Geophysical Journal International, 182(2), 613-630, doi:10.1111/j.1365-246x.2010.04659.x.

Rowley, D. B. (2002), Rate of plate creation and destruction: 180 Ma to present, GSA Bulletin, 114(8), 927-933, doi:10.1130/00167606(2002)114;0927:ropcad ¿2.0.co;2.

Royden, L. H., and L. Husson (2006), Trench motion, slab geometry and viscous stresses in subduction systems, Geophysical Journal International, 167(2), 881-905, doi:10.1111/j.1365-246x.2006.03079.x.

Rozel, A., Y. Ricard, and D. Bercovici (2011), A thermodynamically selfconsistent damage equation for grain size evolution during dynamic recrystallization, Geophysical Journal International, 184(2), 719-728.

Rozel, A., G. J. Golabek, R. Nf, and P. J. Tackley (2015), Formation of ridges in a stable lithosphere in mantle convection models with a viscoplastic rheology, Geophys. Res. Lett., 42(12), 4770-4777, doi:10.1002/2015GL063483.

Rudolph, M. L., V. Lekić, and C. Lithgow-Bertelloni (2015), Viscosity jump in Earths mid-mantle, Science, 350(6266), 1349, doi: 10.1126/science.aad1929.

Ruedas, T., H. Schmeling, G. Marquart, A. Kreutzmann, and A. Junge (2004), Temperature and melting of a ridge-centred plume with application to iceland. Part I: Dynamics and crust production, Geophysical Journal International, 158(2), 729-743, doi:10.1111/j.1365-246X.2004.02311.x.

Ruff, L., and H. Kanamori (1980), Seismicity and the subduction process, Physics of the Earth and Planetary Interiors, 23(3), 240-252, doi: 10.1016/0031-9201(80)90117-X.

Russo, R. M., and P. G. Silver (1994), Trench-parallel flow beneath the Nazca plate from seismic anisotropy, Science, 263(5150), 1105-1111, doi: 10.1126/science.263.5150.1105. 
Sæmundsson, K. (1974), Evolution of the axial rifting zone in northern Iceland and the Tjörnes fracture zone, GSA Bulletin, 85(4), 495-504, doi: 10.1130/0016-7606(1974)85¡495:EOTARZ;2.0.CO;2.

Sandu, C., A. Lenardic, and P. McGovern (2011), The effects of deep water cycling on planetary thermal evolution, J. Geophys. Res., 116(B12), doi: 10.1029/2011JB008405.

Sandwell, D. T., and G. Schubert (1992), Evidence for retrograde lithospheric subduction on Venus, Science, 257(5071), 766, doi: 10.1126/science.257.5071.766.

Sarafian, E., R. Evans, J. A. Collins, J. Elsenbeck, G. A. Gaetani, J. B. Gaherty, G. Hirth, D. Lizarralde, et al. (2015), The electrical structure of the central Pacific upper mantle constrained by the NoMelt experiment, Geochemistry, Geophysics, Geosystems, 16(4), 1115-1132, doi: 10.1002/2014GC005709.

Sarafian, E., G. A. Gaetani, E. H. Hauri, and A. R. Sarafian (2017), Experimental constraints on the damp peridotite solidus and oceanic mantle potential temperature, Science, 355(6328), 942-945, doi: 10.1126/science.aaj2165.

Schellart, W., D. Stegman, and J. Freeman (2008), Global trench migration velocities and slab migration induced upper mantle volume fluxes: Constraints to find an Earth reference frame based on minimizing viscous dissipation, Earth-Science Reviews, 88(1-2), 118-144.

Schellart, W. P. (2004), Kinematics of subduction and subduction-induced flow in the upper mantle, J. Geophys. Res., 109(B7), B07,401.

Schellart, W. P., J. Freeman, D. R. Stegman, L. Moresi, and D. May (2007), Evolution and diversity of subduction zones controlled by slab width, $\mathrm{Na}$ ture, 446, 308-311.

Schilling, J., G. Thompson, R. Kingsley, and S. Humphris (1985), Hotspotmigrating ridge interaction in the South Atlantic, Nature, 313(5999), 187191.

Schilling, J.-G. (1973), Iceland mantle plume: geochemical study of Reykjanes Ridge, Nature, 242, 565-571, doi:10.1038/242565a0. 
Schilling, J.-G. (1991), Fluxes and excess temperatures of mantle plumes inferred from their interaction with migrating mid-ocean ridges, Nature, 352, 397-403, doi:10.1038/352397a0.

Schlindwein, V., and F. Schmid (2016), Mid-ocean-ridge seismicity reveals extreme types of ocean lithosphere, Nature, 535(7611), 276-287, doi: 10.1038 /nature18277.

Schmeling, H., R. Monz, and D. C. Rubie (1999), The influence of olivine metastability on the dynamics of subduction, Earth and Planetary Science Letters, 165(1), 55-66, doi:10.1016/S0012-821X(98)00249-0.

Schmeling, H., A. Babeyko, A. Enns, C. Faccenna, F. Funiciello, T. Gerya, G. Golabek, S. Grigull, B. Kaus, G. Morra, S. Schmalholz, and J. van Hunen (2008), A benchmark comparison of spontaneous subduction models-Towards a free surface, Physics of the Earth and Planetary Interiors, 171 (1-4), 198-223, doi:10.1016/j.pepi.2008.06.028.

Schmid, F., and V. Schlindwein (2016), Microearthquake activity, lithospheric structure, and deformation modes at an amagmatic ultraslow spreading Southwest Indian Ridge segment, Geochemistry, Geophysics, Geosystems, 17(7), 2905-2921, doi:10.1002/2016GC006271.

Schouten, H., K. D. Klitgord, and J. A. Whitehead (1985), Segmentation of mid-ocean ridges, Nature, 317 (6034), 225-229.

Schubert, G., and D. T. Sandwell (1995), A global survey of possible subduction sites on Venus, Icarus, 117(1), 173-196, doi:10.1006/icar.1995.1150.

Scott, D. J., H. Helmstaedt, and M. J. Bickle (1992), Purtuniq ophiolite, Cape Smith belt, northern Quebec, Canada: A reconstructed section of Early Proterozoic oceanic crust, Geology, 20(2), 173-176, doi: 10.1130/0091-7613(1992)020;0173:pocsbn¿2.3.co;2.

Sdrolias, M., and R. D. Müller (2006), Controls on back-arc basin formation, Geochem. Geophys. Geosyst., 7(4), Q04,016.

Seton, M., R. D. Müller, S. Zahirovic, C. Gaina, T. Torsvik, G. Shephard, A. Talsma, M. Gurnis, M. Turner, S. Maus, and M. Chandler (2012), Global continental and ocean basin reconstructions since 200Ma, EarthScience Reviews, 113(3), 212-270, doi:10.1016/j.earscirev.2012.03.002. 
Shaw, A. M., M. D. Behn, S. E. Humphris, R. A. Sohn, and P. M. Gregg (2010), Deep pooling of low degree melts and volatile fluxes at the $85 \mathrm{E}$ segment of the Gakkel Ridge: Evidence from olivine-hosted melt inclusions and glasses, Earth and Planetary Science Letters, 289(3), 311-322, doi: 10.1016/j.epsl.2009.11.018.

Shen, Y., and D. W. Forsyth (1992), The effects of temperature-and pressuredependent viscosity on three-dimensional passive flow of the mantle beneath a ridge-transform system, Journal of Geophysical Research: Solid Earth, 97(B13), 19,717-19,728.

Shephard, G. E., K. J. Matthews, K. Hosseini, and M. Domeier (2017), On the consistency of seismically imaged lower mantle slabs, Scientific Reports, 7(1), 10,976, doi:10.1038/s41598-017-11039-w.

Sigloch, K., and M. G. Mihalynuk (2013), Intra-oceanic subduction shaped the assembly of Cordilleran North America, Nature, 496(7443), 50.

Sinha, M. C., and R. L. Evans (2004), Gephysical constraints upon the thermal regime of the ocean crust, Mid-Ocean Ridges, pp. 19-62.

Sleep, N. H. (1975), Formation of oceanic crust: some thermal constraints, Journal of Geophysical Research, 80(29), 4037-4042, doi: 10.1029/JB080i029p04037.

Sleep, N. H. (2000), Evolution of the mode of convection within terrestrial planets, J. Geophys. Res., 105(E7), 17,563-17,578.

Sleep, N. H., and J. M. Warren (2014), Effect of latent heat of freezing on crustal generation at low spreading rates, Geochemistry, Geophysics, Geosystems, 15(8), 3161-3174.

Sleep, N. H., and B. F. Windley (1982), Archean plate tectonics: constraints and inferences, The Journal of Geology, 90(4), 363-379.

Solomatov, V. S. (1995), Scaling of temperature- and stress-dependent viscosity convection, Physics of Fluids, 7, 266.

Solomatov, V. S. (2004), Initiation of subduction by small-scale convection, J. Geophys. Res., $109(\mathrm{~B} 1), \mathrm{B} 01,412$. 
Sparks, D. W., and E. Parmentier (1991), Melt extraction from the mantle beneath spreading centers, Earth and Planetary Science Letters, 105(4), $368-377$.

Sparks, D. W., E. Parmentier, and J. P. Morgan (1993), Three-dimensional mantle convection beneath a segmented spreading center: Implications for along-axis variations in crustal thickness and gravity, Journal of Geophysical Research: Solid Earth, 98(B12), 21,977-21,995.

Spasojevic, S., M. Gurnis, and R. Sutherland (2010), Mantle upwellings above slab graveyards linked to the global geoid lows, Nature Geoscience, 3(6), 435, doi:10.1038/ngeo855.

Spiegelman, M. (1993), Physics of melt extraction: Theory, implications and applications, Philosophical Transactions: Physical Sciences and Engineering, pp. 23-41.

Spiegelman, M., and D. McKenzie (1987), Simple 2-d models for melt extraction at mid-ocean ridges and island arcs, Earth and Planetary Science Letters, 83(1), 137-152.

Spiegelman, M., P. B. Kelemen, and E. Aharonov (2001), Causes and consequences of flow organization during melt transport: The reaction infiltration instability in compactible media, Journal of Geophysical Research: Solid Earth, 106(B2), 2061-2077, doi:10.1029/2000JB900240.

Stampfli, G., and G. Borel (2002), A plate tectonic model for the Paleozoic and Mesozoic constrained by dynamic plate boundaries and restored synthetic oceanic isochrons, Earth and Planetary Science Letters, 196(12), $17-33$.

Stegman, D., W. Schellart, and J. Freeman (2010a), Competing influences of plate width and far-field boundary conditions on trench migration and morphology of subducted slabs in the upper mantle, Tectonophysics, 483(1-2), 46-57.

Stegman, D., R. Farrington, F. Capitanio, and W. Schellart (2010b), A regime diagram for subduction styles from $3-\mathrm{D}$ numerical models of free subduction, Tectonophysics, 483(1-2), 29-45. 
Stein, C. A., and S. Stein (1992), A model for the global variation in oceanic depth and heat flow with lithospheric age, Nature, 359(6391), 123-129.

Stein, C. A., and S. Stein (1994), Comparison of plate and asthenospheric flow models for the thermal evolution of oceanic lithosphere, Geophysical Research Letters, 21(8), 709-712.

Stein, S. (1978), A model for the relation between spreading rate and oblique spreading, Earth and Planetary Science Letters, 39(3), 313-318.

Steinberger, B., and T. H. Torsvik (2012), A geodynamic model of plumes from the margins of Large Low Shear Velocity Provinces, Geochem. Geophys. Geosyst., 13(1), doi:10.1029/2011GC003808.

Steiner, S. A., and C. P. Conrad (2007), Does active mantle upwelling help drive plate motions?, Physics of the Earth and Planetary Interiors, 161 (1), 103-114, doi:10.1016/j.pepi.2007.01.005.

Stengel, K. C., D. S. Oliver, and J. R. Booker (1982), Onset of convection in a variable-viscosity fluid, Journal of Fluid Mechanics, 120, 411-431, doi:10.1017/S0022112082002821.

Stern, R. (2007), When and how did plate tectonics begin? Theoretical and empirical considerations, Chinese Science Bulletin 52, 52(5), 578-591.

Stevenson, D. J. (1989), Spontaneous small-scale melt segregation in partial melts undergoing deformation, Geophysical Research Letters, 16(9), 10671070 .

Tackley, P. J. (1998), Three-dimensional simulations of mantle convection with a thermo-chemical basal boundary layer: D"?, in The CoreMantle Boundary Region, edited by M. Gurnis, M. E. Wysession, E. Knittle, and B. A. Buffett, pp. 231-253, American Geophysical Union, doi: 10.1029/GD028p0231.

Tackley, P. J. (2000), Self-consistent generation of tectonic plates in timedependent, three-dimensional mantle convection simulations - Part 1: Pseudo-plastic yielding, Geochem. Geophys. Geosyst., 1(8), 1-45.

Tackley, P. J. (2002), Strong heterogeneity caused by deep mantle layering, Geochem.-Geophys.-Geosyst., 3(4), 1-22, doi:10.1029/2001GC000167. 
Tackley, P. J. (2008), Modelling compressible mantle convection with large viscosity contrasts in a three-dimensional spherical shell using the yinyang grid, Physics of the Earth and Planetary Interiors, 171(1-4), 7-18, doi:10.1016/j.pepi.2008.08.005.

Tackley, P. J. (2011), Living dead slabs in 3-D: The dynamics of compositionally-stratified slabs entering a "slab graveyard" above the coremantle boundary, Physics of the Earth and Planetary Interiors, 188(3-4), 150-162, doi:10.1016/j.pepi.2011.04.013.

Tagawa, M., T. Nakakuki, M. Kameyama, and F. Tajima (2007), The role of history-dependent rheology in plate boundary lubrication for generating one-sided subduction, Pure and Applied Geophysics, 164(5), 879-907.

Taylor, B., K. Crook, and J. Sinton (1994), Extensional transform zones and oblique spreading centers, Journal of Geophysical Research: Solid Earth, 99(B10), 19,707-19,718, doi:10.1029/94JB01662.

Taylor, B., A. Goodliffe, and F. Martinez (2009), Initiation of transform faults at rifted continental margins, Comptes Rendus Geoscience, 341(5), 428-438.

Team, T. M. S. (1998), Imaging the deep seismic structure beneath a MidOcean Ridge: The MELT Experiment, Science, 280(5367), 1215-1218, doi:10.1126/science.280.5367.1215.

Theissen-Krah, S., L. H. Rüpke, and J. Hasenclever (2016), Modes of crustal accretion and their implications for hydrothermal circulation, Geophysical Research Letters, 43(3), 1124-1131, doi:10.1002/2015GL067335.

Thielmann, M., and B. J. Kaus (2012), Shear heating induced lithosphericscale localization: Does it result in subduction?, Earth and Planetary Science Letters, 359/360(0), 1-13.

Thomson, A. R., M. J. Walter, S. C. Kohn, and R. A. Brooker (2016), Slab melting as a barrier to deep carbon subduction, Nature, 529(7584), 76-79, doi:10.1038/nature16174.

Tivey, M. K. (2007), Generation of seafloor hydrothermal vent fluids and associated mineral deposits, Oceanography, 20(1), 50-65. 
Toomey, D. R., D. Jousselin, R. A. Dunn, W. S. Wilcock, and R. Detrick (2007), Skew of mantle upwelling beneath the East Pacific Rise governs segmentation, Nature, 446(7134), 409.

Torsvik, T., and L. Cocks (2016a), Earths Origins and the Precambrian, in Earth History and Palaeogeography, pp. 38-76, Cambridge University Press, Cambridge, doi:10.1017/9781316225523.005.

Torsvik, T. H., and L. R. M. Cocks (2016b), Earth History and Palaeogeography, Cambridge University Press, Cambridge, doi:10.1017/9781316225523.

Torsvik, T. H., and B. Steinberger (2006), Fra kontinentaldrift til manteldynamikk, Geo, 8, 20-30.

Torsvik, T. H., and B. Steinberger (2008), Geology for Society for 150 Years The legacy after Kjerulf, chap. From continental drift to mantle dynamics, pp. 24-38, Geological Survey of Norway.

Torsvik, T. H., H. Amundsen, E. H. Hartz, F. Corfu, N. Kusznir, C. Gaina, P. V. Doubrovine, B. Steinberger, L. D. Ashwal, and B. Jamtveit (2013), A precambrian microcontinent in the Indian Ocean, Nature geoscience, 6(3), 223.

Torsvik, T. H., R. van der Voo, P. V. Doubrovine, K. Burke, B. Steinberger, L. D. Ashwal, R. G. Trnnes, S. J. Webb, and A. L. Bull (2014), Deep mantle structure as a reference frame for movements in and on the Earth, Proceedings of the National Academy of Sciences, 111(24), 8735-8740.

Torsvik, T. H., H. E. Amundsen, R. G. Trønnes, P. V. Doubrovine, C. Gaina, N. J. Kusznir, B. Steinberger, F. Corfu, L. D. Ashwal, W. L. Griffin, et al. (2015), Continental crust beneath southeast Iceland, Proceedings of the National Academy of Sciences, 112(15), E1818-E1827.

Torsvik, T. H., B. Steinberger, L. D. Ashwal, P. V. Doubrovine, and R. G. Trønnes (2016), Earth evolution and dynamics-a tribute to kevin burke, Canadian Journal of Earth Sciences, 53(11), 1073-1087, doi:10.1139/cjes2015-0228.

Toth, J., and M. Gurnis (1998), Dynamics of subduction initiation at preexisting fault zones, J. Geophys. Res., 103(B8), 18,053-18,067. 
Tovish, A., and S. Gerald (1978), Island arc curvature, velocity of convergence and angle of subduction, Geophys. Res. Lett., 5(5), 329-332.

Tovish, A., G. Schubert, and B. P. Luyendyk (1978), Mantle flow pressure and the angle of subduction: Non-Newtonian corner flows, J. Geophys. Res., 83(B12), 5892-5898.

Trampert, J., F. Deschamps, J. Resovsky, and D. Yuen (2004), Probabilistic tomography maps chemical heterogeneities throughout the lower mantle, Science, 306(5697), 853, doi:10.1126/science.1101996.

Tucholke, B. E., J. Lin, and M. C. Kleinrock (1998), Megamullions and mullion structure defining oceanic metamorphic core complexes on the MidAtlantic Ridge, Journal of Geophysical Research: Solid Earth, 103(B5), 9857-9866.

Turcotte, D. L., and E. Oxburgh (1972), Mantle convection and the new global tectonics, Annual Review of Fluid Mechanics, 4 (1), 33-66.

Turcotte, D. L., and E. R. Oxburgh (1967), Finite amplitude convective cells and continental drift, Journal of Fluid Mechanics, 28(01), 29-42, doi:10.1017/S0022112067001880.

Turcotte, D. L., and G. Schubert (2014), Geodynamics, 3rd ed., Cambridge University Press, New York.

Turner, A. J., R. F. Katz, and M. D. Behn (2015), Grain-size dynamics beneath mid-ocean ridges: Implications for permeability and melt extraction, Geochemistry, Geophysics, Geosystems, 16(3), 925-946, doi: 10.1002/2014GC005692.

Turner, A. J., R. F. Katz, M. D. Behn, and T. Keller (2017), Magmatic focusing to mid-ocean ridges: the role of grain size variability and nonNewtonian viscosity, arXiv preprint arXiv:1706.00609.

Ueda, K., T. Gerya, and S. V. Sobolev (2008), Subduction initiation by thermal-chemical plumes: Numerical studies, Physics of the Earth and Planetary Interiors, 171(1-4), 296-312.

Uyeda, S., and H. Kanamori (1979), Back-arc opening and the mode of subduction, J. Geophys. Res., 84(B3), 1049-1061, doi: 10.1029/JB084iB03p01049. 
Van der Beek, B. P., D. R. Toomey, E. E. Hooft, and W. S. Wilcock (2016), Segmentation of mid-ocean ridges attributed to oblique mantle divergence, Nature Geoscience, 9(8), 636-642, doi:10.1038/ngeo2745.

van der Hilst, R., E. Engdahl, W. Spakman, and G. Nolet (1991), Tomographic imaging of subducted lithosphere below northwest Pacific island arcs, Nature, 353, 37-42.

van der Meer, D. G., G. Douwe, R. E. Zeebe, D. J. J. van Hinsbergen, A. Sluijs, W. Spakman, and T. H. Torsvik (2014), Plate tectonic controls on atmospheric CO2 levels since the Triassic, Proceedings of the National Academy of Sciences, 111(12), 4380-4385, doi:10.1073/pnas.1315657111.

van Hunen, J., and J.-F. Moyen (2012), Archean Subduction: Fact or Fiction?, Annu. Rev. Earth Planet. Sci., 40(1), 195-219, doi: 10.1146/annurev-earth-042711-105255.

van Hunen, J., A. P. van den Berg, and N. J. Vlaar (2004), Various mechanisms to induce present-day shallow flat subduction and implications for the younger Earth: a numerical parameter study, Physics of the Earth and Planetary Interiors, 146(1-2), 179-194.

van Hunen, J., S. Zhong, N. M. Shapiro, and M. H. Ritzwoller (2005), New evidence for dislocation creep from 3-D geodynamic modeling of the Pacific upper mantle structure, Earth and Planetary Science Letters, 238(1), 146155, doi:10.1016/j.epsl.2005.07.006.

van Hunen, J., P. E. van Keken, A. Hynes, and G. F. Davies (2008), Tectonics of early Earth: Some geodynamic considerations, in When Did Plate Tectonics Begin on Planet Earth?, edited by K. C. Condie and V. Pease, Geological Society of America, doi:10.1130/2008.2440(08).

van Keken, E. Peter, B. R. Hacker, E. M. Syracuse, and G. A. Abers (2011), Subduction factory: 4. Depth-dependent flux of $\mathrm{H} 2 \mathrm{O}$ from subducting slabs worldwide, J. Geophys. Res., 116(B1), doi:10.1029/2010JB007922.

Č́źzová, H., and C. R. Bina (2013), Effects of mantle and subductioninterface rheologies on slab stagnation and trench rollback, Earth and Planetary Science Letters, 379, 95-103. 
Vera, E., J. Mutter, P. Buhl, J. Orcutt, A. Harding, M. Kappus, R. Detrick, and T. Brocher (1990), The structure of 0-to 0.2-my-old oceanic crust at $9 \mathrm{~N}$ on the East Pacific Rise from expanded spread profiles, Journal of Geophysical Research: Solid Earth, 95 (B10), 15,529-15,556.

Vine, F. J. (1966), Spreading of the ocean floor: New evidence, Science, 154(3755), 1405-1415, doi:10.1126/science.154.3755.1405.

Vine, F. J., and D. Matthews (1963), Magnetic anomalies over oceanic ridges, Nature, 199(4897), 947-949, doi:10.1038/199947a0.

Vlaar, N., and M. Wortel (1976), Lithospheric aging, instability and subduction, Tectonophysics, 32(3-4), 331-351.

Vogt, P. (1971), Asthenosphere motion recorded by the ocean floor south of Iceland, Earth and Planetary Science Letters, 13(1), 153-160.

Vogt, P., P. Taylor, L. Kovacs, and G. Johnson (1979), Detailed aeromagnetic investigation of the Arctic Basin, Journal of Geophysical Research: Solid Earth, 84(B3), 1071-1089.

Von Damm, K., J. Edmond, B. Grant, C. Measures, B. Walden, and R. Weiss (1985), Chemistry of submarine hydrothermal solutions at 21 N, East Pacific Rise, Geochimica et Cosmochimica Acta, 49(11), 2197-2220.

Wadati, K. (1935), On the activity of deep-focus earthquakes in the Japan Islands and neighbourhoods, Geophys. Mag, 8, 305-326.

Waldron, J. W. F., D. I. Schofield, J. B. Murphy, and C. W. Thomas (2014), How was the Iapetus ocean infected with subduction?, Geology, 42(12), 1095-1098.

Walter, M. J., T. W. Sisson, and D. C. Presnall (1995), A mass proportion method for calculating melting reactions and application to melting of model upper mantle lherzolite, Earth and Planetary Science Letters, 135(1-4), 77-90.

Wanless, V., M. Behn, A. Shaw, and T. Plank (2014), Variations in melting dynamics and mantle compositions along the Eastern Volcanic Zone of the Gakkel Ridge: insights from olivine-hosted melt inclusions, Contributions to Mineralogy and Petrology, 167(5), 1005, doi:10.1007/s00410-014-1005-7. 
Warren, J. M. (2016), Global variations in abyssal peridotite compositions, lithos, 248, 193-219.

Warren, J. M., and E. H. Hauri (2014), Pyroxenes as tracers of mantle water variations, Journal of Geophysical Research: Solid Earth, 119(3), 18511881, doi:10.1002/2013JB010328.

Watkins, C. E., and C. P. Conrad (2018), Constraints on dynamic topography from asymmetric subsidence of the mid-ocean ridges, Earth and Planetary Science Letters, 484, 264-275, doi:10.1016/j.epsl.2017.12.028.

Weatherley, S. M., and R. F. Katz (2010), Plate-driven mantle dynamics and global patterns of mid-ocean ridge bathymetry, Geochemistry, Geophysics, Geosystems, 11(10), doi:10.1029/2010GC003192.

Wegener, A. (1912), Die Entstehung der Kontinente, Geologische Rundschau, 3(4), 276-292, doi:10.1007/BF02202896.

White, R., T. Minshull, M. Bickle, and C. Robinson (2001), Melt generation at very slow-spreading oceanic ridges: Constraints from geochemical and geophysical data, Journal of Petrology, 42(6), 1171-1196.

Williams, D. L., and R. P. Von Herzen (1974), Heat loss from the Earth: new estimate, Geology, 2(7), 327-328.

Wilson, D. S., and R. N. Hey (1995), History of rift propagation and magnetization intensity for the Cocos-Nazca sspreading Center, Journal of Geophysical Research: Solid Earth, 100 (B6), 10,041-10,056.

Wilson, D. S., R. N. Hey, and C. Nishimura (1984), Propagation as a mechanism of reorientation of the Juan de Fuca Ridge, Journal of Geophysical Research: Solid Earth, 89(B11), 9215-9225, doi:10.1029/JB089iB11p09215.

Wilson, T. (1966), Did the Atlantic close and then re-open?, Nature, 211(5050), 676-681, doi:http://dx.doi.org/10.1038/211676a0.

Winslow, D. M., and A. T. Fisher (2015), Sustainability and dynamics of outcrop-to-outcrop hydrothermal circulation, Nature communications, 6, doi:10.1038/ncomms8567. 
Winterbourne, J., N. White, and A. Crosby (2014), Accurate measurements of residual topography from the oceanic realm, Tectonics, 33(6), 982-1015, doi:10.1002/2013TC003372.

Wolery, T. J., and N. H. Sleep (1976), Hydrothermal circulation and geochemical flux at mid-ocean ridges, The Journal of Geology, 84 (3), 249-275.

Workman, R. K., and S. R. Hart (2005), Major and trace element composition of the depleted MORB mantle (DMM), Earth and Planetary Science Letters, 231(1-2), 53-72, doi:10.1016/j.epsl.2004.12.005.

Workman, R. K., S. R. Hart, M. Jackson, M. Regelous, K. Farley, J. Blusztajn, M. Kurz, and H. Staudigel (2004), Recycled metasomatized lithosphere as the origin of the Enriched Mantle II (EM2) end-member: Evidence from the Samoan Volcanic Chain, Geochemistry, Geophysics, Geosystems, 5(4).

Wortel, M. J. R., and W. Spakman (2000), Subduction and slab detachment in the Mediterranean-Carpathian region, Science, 290(5498), 1910-1917, doi:10.1126/science.290.5498.1910.

Wu, B., C. P. Conrad, A. Heuret, C. Lithgow-Bertelloni, and S. Lallemand (2008), Reconciling strong slab pull and weak plate bending: The plate motion constraint on the strength of mantle slabs, Earth and Planetary Science Letters, 272(1-2), 412-421, doi:10.1016/j.epsl.2008.05.009.

Xu, X., C. Lithgow-Bertelloni, and C. P. Conrad (2006), Global reconstructions of Cenozoic seafloor ages: Implications for bathymetry and sea level, Earth and Planetary Science Letters, 243(3), 552-564, doi: 10.1016/j.epsl.2006.01.010.

Yang, T., M. Gurnis, and S. Zahirovic (2016), Slab avalancheinduced tectonics in self-consistent dynamic models, Tectonophysics, doi: 10.1016/j.tecto.2016.12.007.

Yoshino, T., D. Yamazaki, and K. Mibe (2009), Well-wetted olivine grain boundaries in partially molten peridotite in the asthenosphere, Earth and Planetary Science Letters, 283(1), 167-173.

Yuen, D. A., L. Fleitout, G. Schubert, and C. Froidevaux (1978), Shear deformation zones along major transform faults and subducting slabs, 
Geophysical Journal International, 54(1), 93-119, doi:10.1111/j.1365246x.1978.tb06758.x.

Zhong, S. (2006), Constraints on thermochemical convection of the mantle from plume heat flux, plume excess temperature, and upper mantle temperature, J. Geophys. Res., 111(B4), doi:10.1029/2005JB003972.

Zhong, S., and M. Gurnis (1994), Controls on trench topography from dynamic models of subducted slabs, J. Geophys. Res., 99 (B8), 15,683-15,695.

Zhong, S., and M. Gurnis (1995), Mantle convection with plates and mobile, faulted plate margins, Science, 267(5199), 838-843.

Zhong, S., and M. Gurnis (1997), Dynamic interaction between tectonic plates, subducting slabs, and the mantle, Earth Interact., 1(3), 1-18, doi: 10.1175/1087-3562(1997)001;0001:DIBTPS;2.3.CO;2.

Zhu, W., G. A. Gaetani, F. Fusseis, L. G. Montési, and F. De Carlo (2011), Microtomography of partially molten rocks: three-dimensional melt distribution in mantle peridotite, Science, 332(6025), 88-91, doi: 10.1126/science.1202221. 


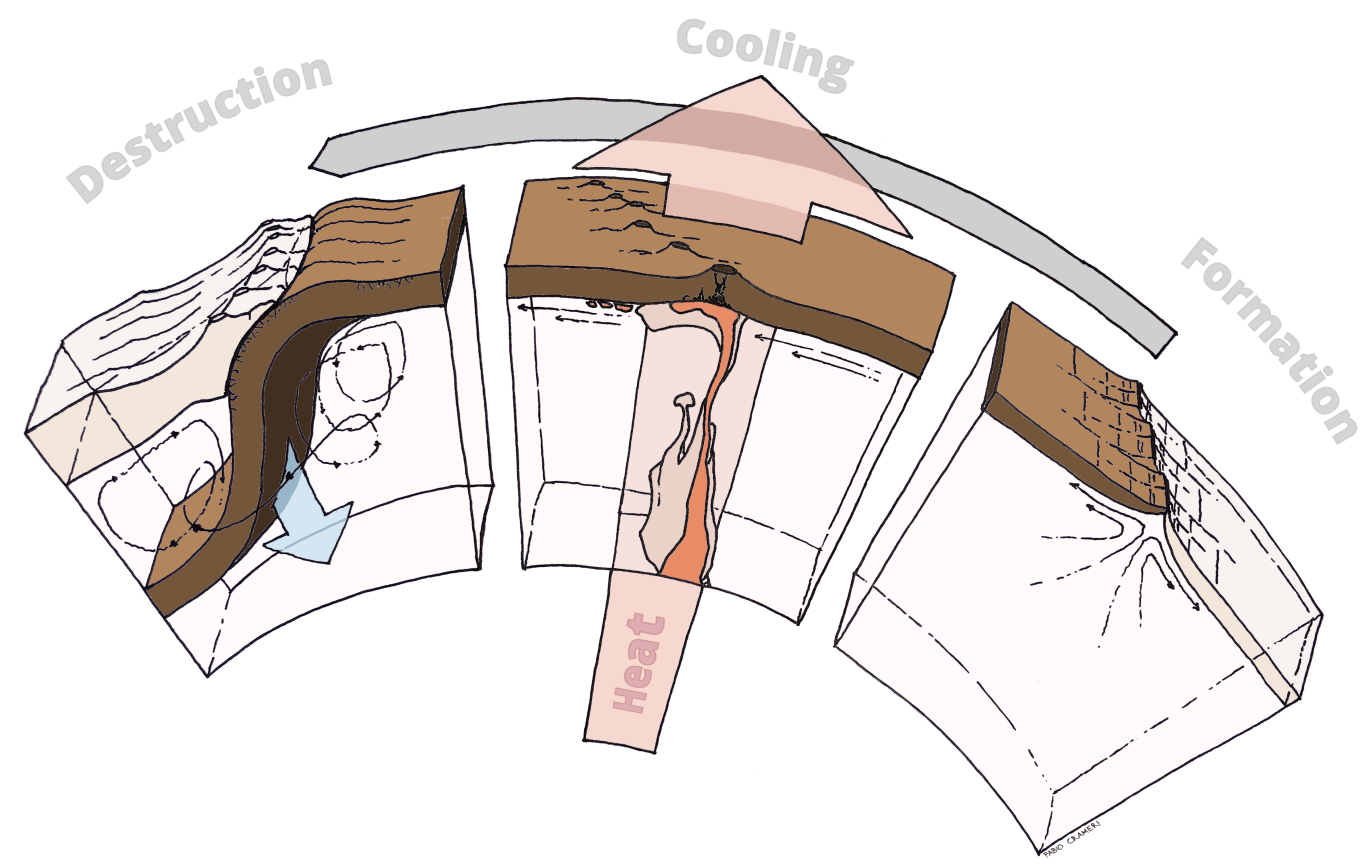

Figure 1: The dynamic life of an oceanic plate. A schematic highlighting the oceanplate formation, cooling and destruction as part of the planet's global mantle convection driven by the temperature gradient between its hot deep interior and the cold surface environment. Ocean-Plate Tectonics is the concept that describes not only the horizontal surface motion of the oceanic plate (grey arrow), but also highlights the pull from its subducted portion as the main driver (blue arrow), distinguishes the oceanic plate (dark brown) from its continental counterpart, acknowledges the plate-mantle coupling that induces characteristic regional mantle-flow patterns (black flow lines), and describes the dynamics of the oceanic plate as part of the larger framework of global mantle convection that transports heat out of the interior (light-red arrow). 


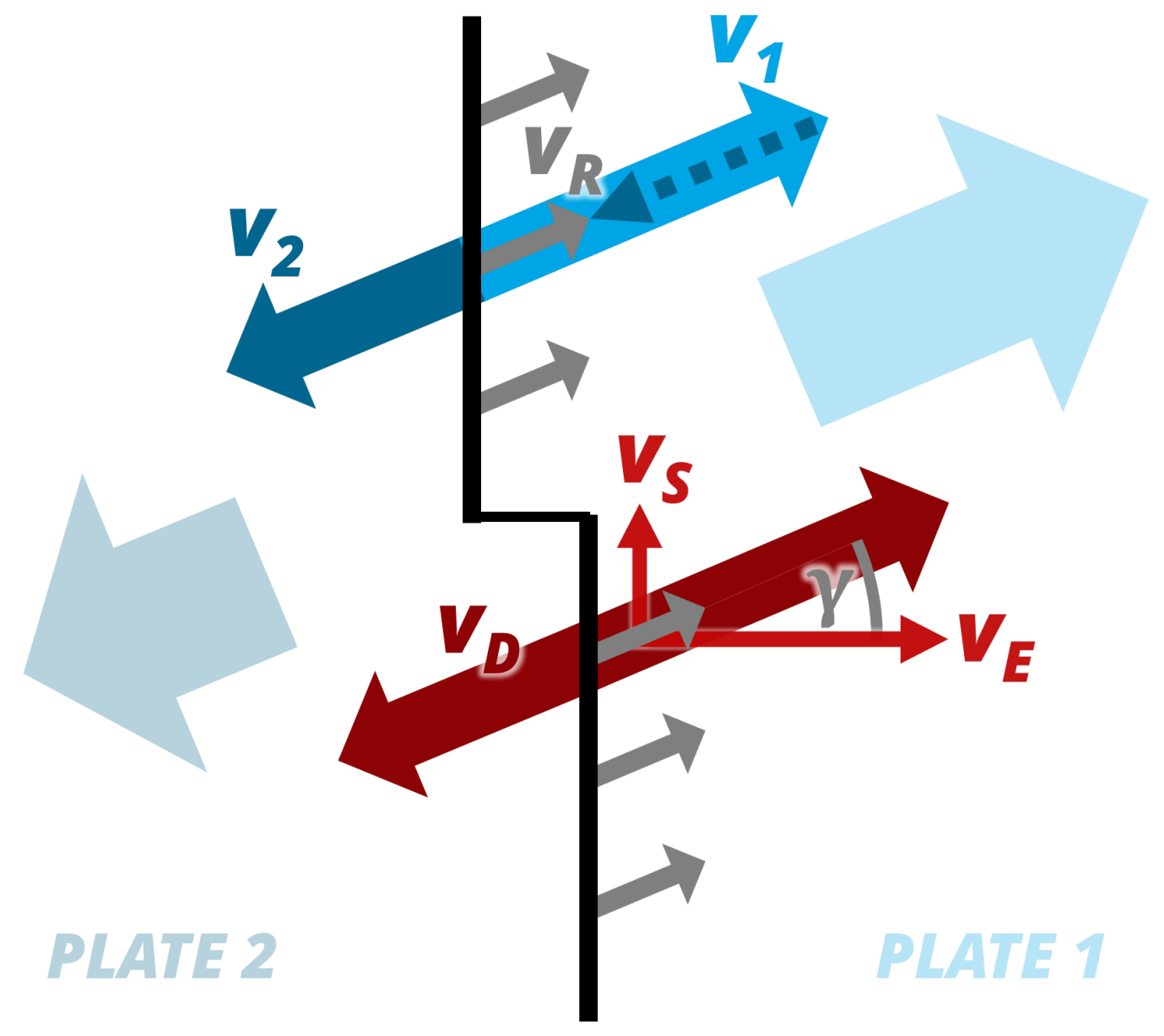

Figure 2: Mid-ocean-ridge spreading definitions. Shown are the top view of a spreading ridge (solid black line) with the asymmetric, diverging-plate velocities ( $V_{1}$ and $\left.V_{2}\right)$, the resulting spreading or plate-divergence rate $\left(V_{D}=V_{1}+V_{2}\right)$, the ridge velocity $\left(V_{R}=\left(V_{1}-V_{2}\right) / 2\right)$ with respect to a fictitious reference point halfway between the two plates, the ridge-normal $\left(V_{E}\right)$ and ridge-parallel $\left(V_{S}\right)$ plate velocity components, and the obliquity angle $\gamma$ (after Montési and Ben, 2007, see text for more details).

97 

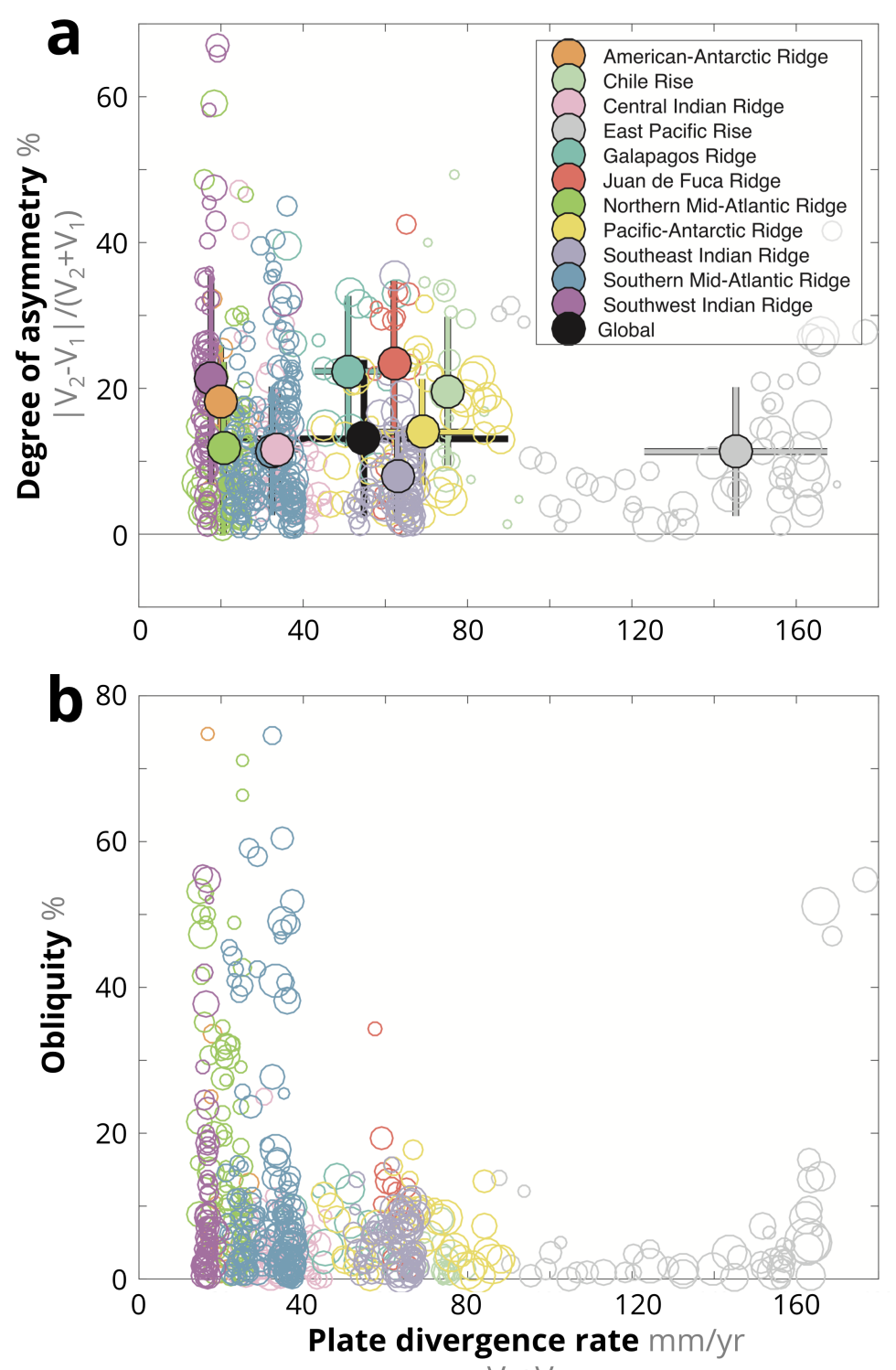

$\mathrm{V}_{2}+\mathrm{V}_{1}$

Figure 3: Mid-ocean-ridge segments asymmetry (a) and obliquity (b). Each open circle represents a single segment and its size is proportional to segment length. Each ridge is associated with a given colour. The solid circles with error bars represent averages over each ridge or a global average (black). The average uses weights proportional to segment length. Data from 600 segments defined by Gale et al. (2013) with kinematics from Müller et al. (2008) compiled by Bai (2017). 

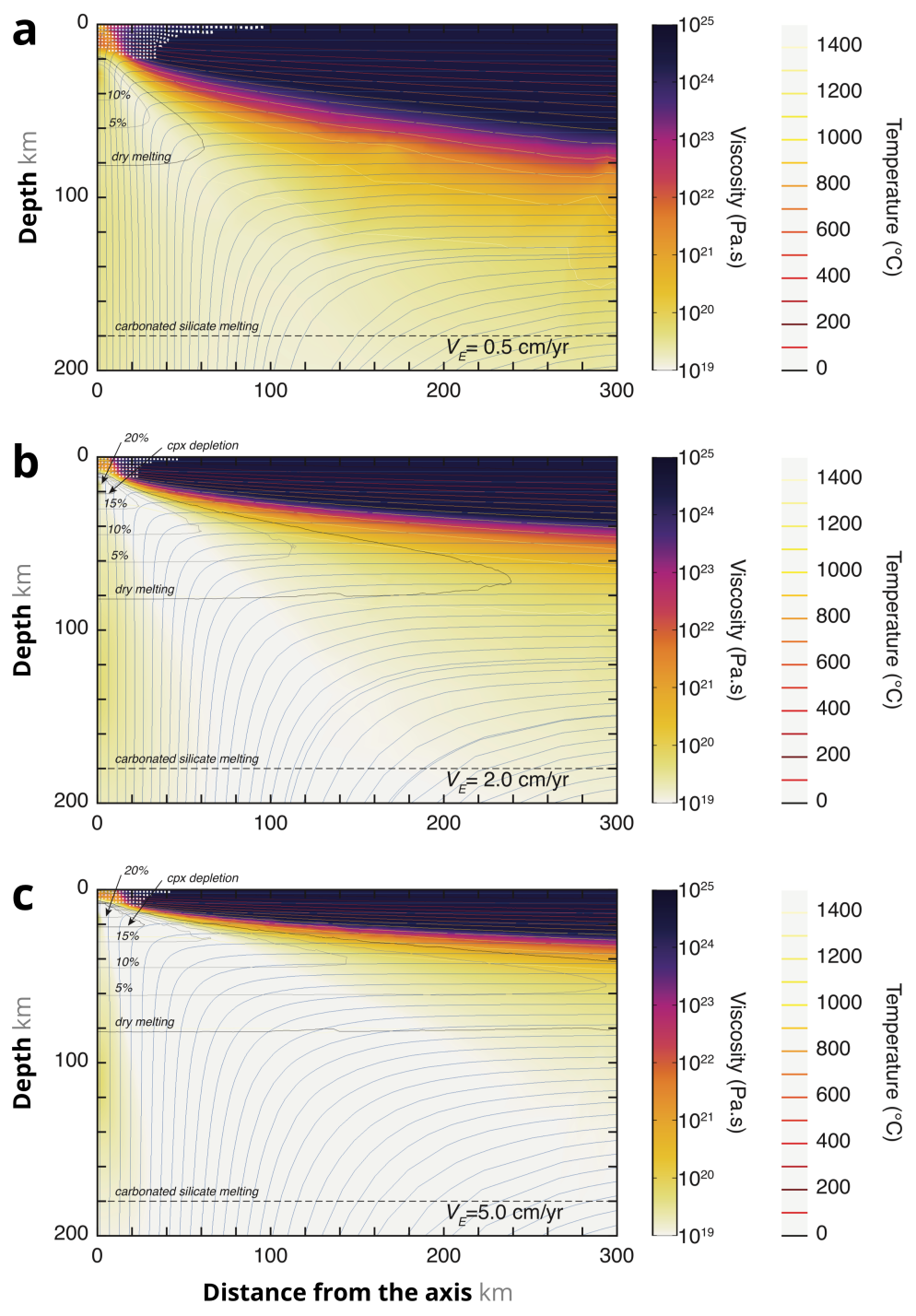

Figure 4: Flow field of a MOR. Flow lines (dark blue), viscosity (coloured field), temperature (coloured contours), and degree of melting (labeled contours) for mid-oceanridge models with spreading rate $\left(V_{E}\right.$, half rate) of (a) $0.5 \mathrm{~cm} / \mathrm{yr}$, (b) $2 \mathrm{~cm} / \mathrm{yr}$, and (c) 5 $\mathrm{cm} / \mathrm{yr}$. The white boxes mark elements where brittle failure takes place. Only the nearaxis part of the model is show. Full model dimensions: $1000-\mathrm{km}$ wide, $300-\mathrm{km}$ tall. Flow is entirely driven by plate divergence (no buoyancy) and the side and bottom boundary conditions are open flow. The viscosity is temperature and strain rate dependent to mimic dislocation creep, diffusion creep, and brittle failure and thermal conductivity is enhanced by a factor up to 8 where brittle failure dominates. Only dry melting is considered, following the description of Katz et al. (2003) with latent heat of fusion $420 \mathrm{~kJ} / \mathrm{kg}$. The effects of melt migration and crystallisation are not included. 


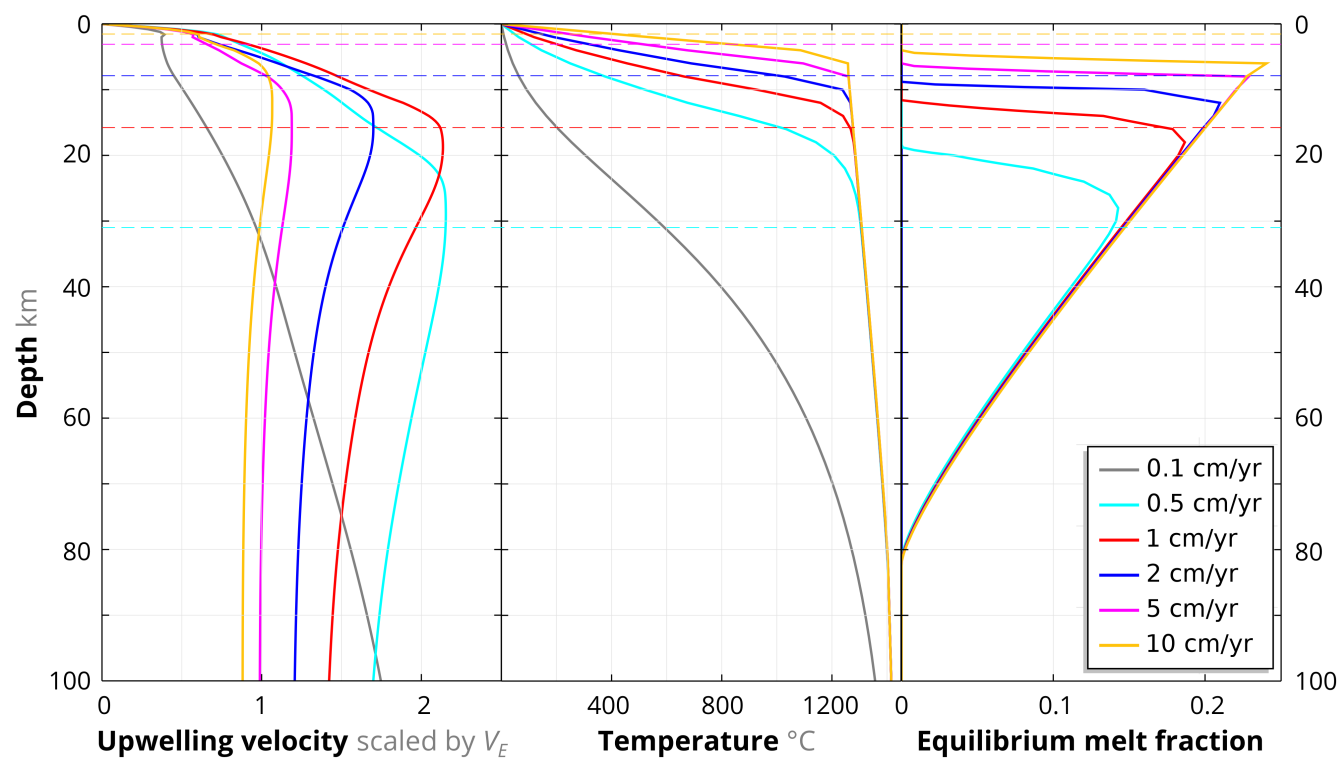

Figure 5: Physical state below a MOR axis. Velocity, temperature, and equilibrium melt fraction taken immediately below the ridge axis from MOR models with different spreading rate $\left(V_{E}\right.$, half rate). No melt is produced at the slower rate of $0.1 \mathrm{~cm} / \mathrm{yr}$. The thin dashed lines mark the base of the lithosphere from the scaling relation in Montési and Behn (2007). Same model setup as in Figure 4. 

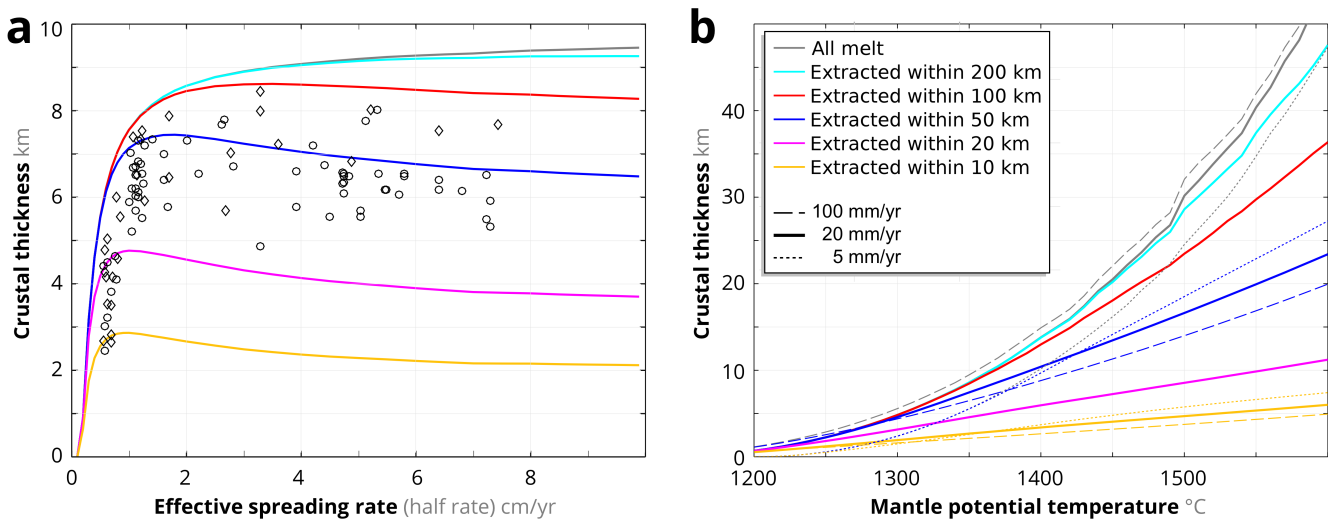

Figure 6: Crustal thickness at a MOR. Prediction of crustal thickness from a numerical model of mid-ocean ridge spreading for (a) different spreading rate and a mantle potential temperature of $1350^{\circ} \mathrm{C}$ and (b) different mantle temperature and an effective spreading rate of $20 \mathrm{~mm} / \mathrm{yr}$ (half rate). Each colour corresponds to a maximum distance to the axis from which the melt can be extracted. Symbols in (a) represent crustal-thickness data from seismic observations (circles) and rare-earth element modelling (diamonds) compiled by White et al. (2001). Same model setup as in Figure 4. 


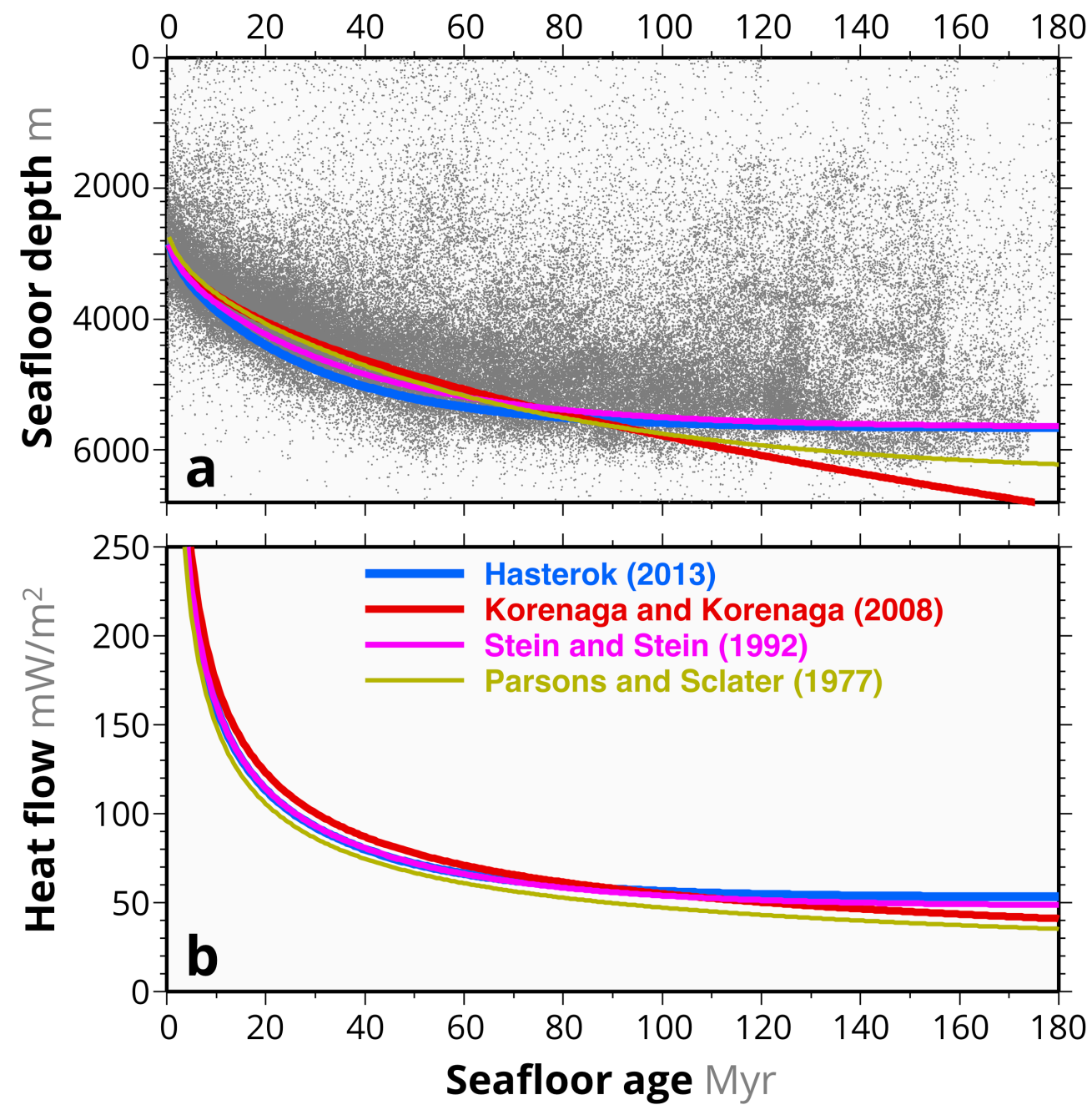

Figure 7: Variation of (a) seafloor depth and (b) mantle heat flow as a function of seafloor age for four different models for the cooling of seafloor away from mid-ocean-ridges, of which three are constrained primarily by seafloor depth observations (Korenaga and Korenaga, 2008; Parsons and Sclater, 1977; Stein and Stein, 1992), and one is primarily constrained by heat-flow observations (Hasterok, 2013) (because heat flow provides no constraint on ridge depth, we assume a value of $2550 \mathrm{~m}$ ). For comparison, we show randomly-selected seafloor depth observations (grey dots, representing $1.65 \%$ of the seafloor) from the 4-minute ETOPO1 topography model (Amante and Eakins, 2009) as a function of seafloor age (Müller et al., 2008). Although the four lithospheric cooling models models predict (a) relatively large differences in the rate of seafloor subsidence away from the ridge, they predict (b) more tightly constrained patterns of decreasing heat flow away from the ridge. 


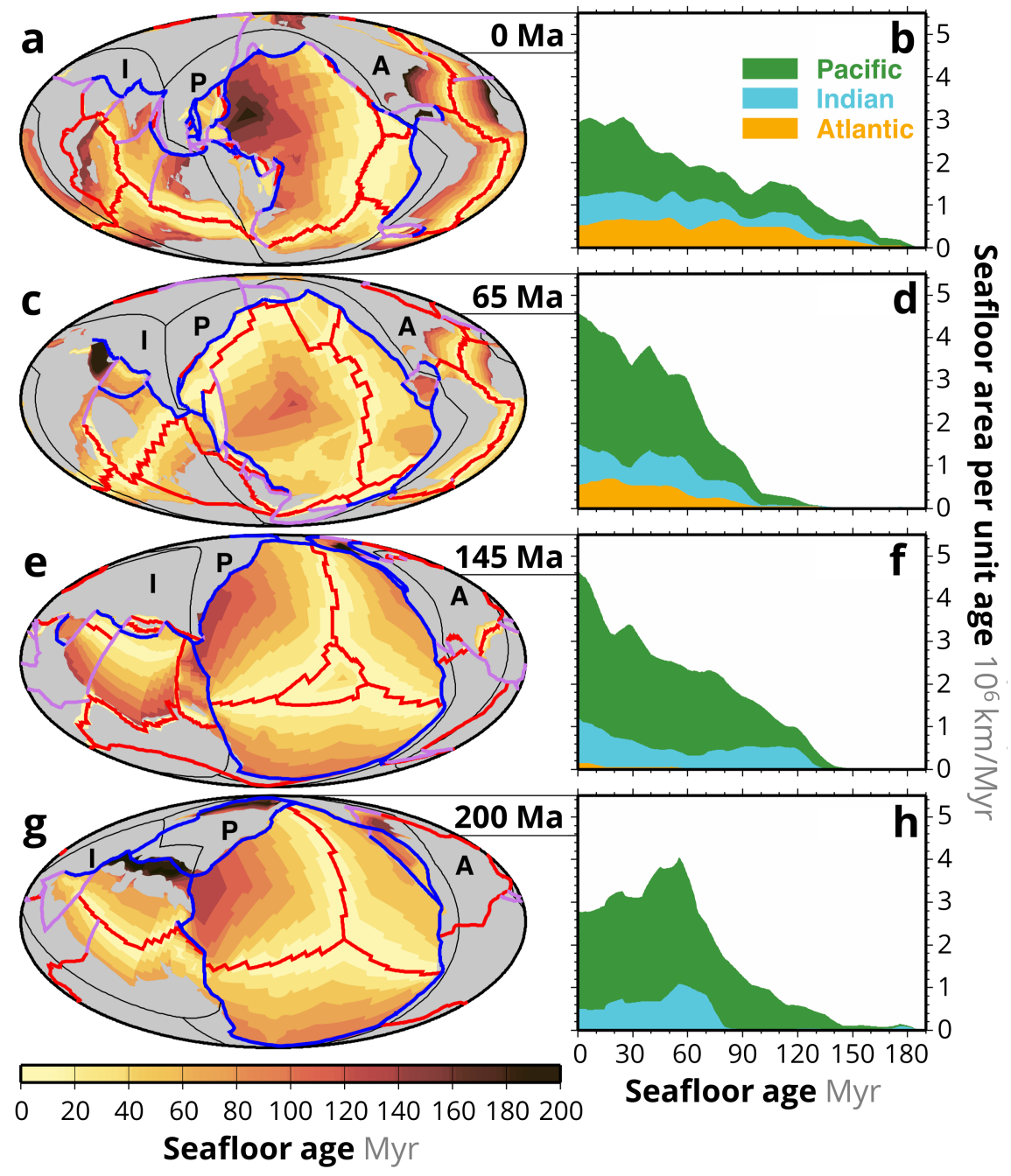

Figure 8: Tectonic reconstructions and seafloor age distributions for (a-b) the present-day (0 Ma), (c-d) the beginning of the Cenozoic (65 Ma), (e-f) the beginning of the Cretaceous (145 Ma), and (g-h) the beginning of the Jurassic (200 Ma), computed using the tectonic reconstruction of Müller et al. (2016). For each age, reconstructed plate boundaries (red, blue, and purple lines refer to divergent, convergent, and transform boundaries, respectively) and seafloor ages (colours in seafloor areas) are shown in map view (left column). Area-age distributions for seafloor areas (right column) reflect changes in seafloor tectonics among the Pacific, Indian, and Atlantic basins, which are denoted in the maps (left column, bounded by thin black lines and labeled as P, I, and A, respectively) and the histograms (right column, cumulative contributions from each basin are denoted by green, blue, and orange colours). 

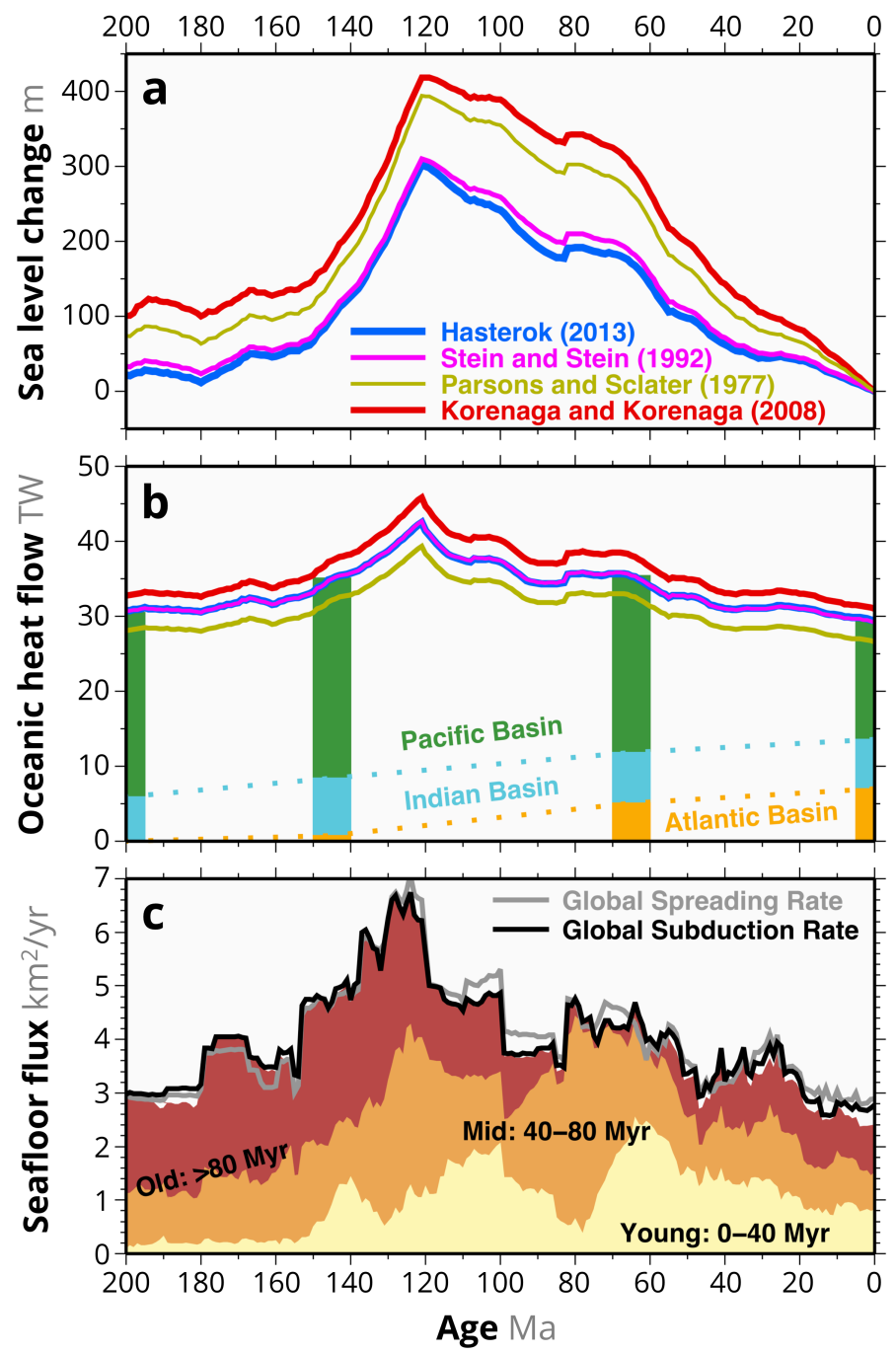

Figure 9: Variations in seafloor characteristics during the past 200 Ma. (a) Changes in average seafloor depth, expressed here as changes in sea level relative to the present-day (assuming isostatic compensation of constant seawater volume) for four lithospheric cooling models (shown in Figure 7) applied to the Müller et al. (2016) seafloor age reconstruction (Figure 8). (b) Oceanic heat flow for the same four models, with the relative contributions of the Pacific, Indian, and Atlantic basins for the four reconstructions shown in Figure 8. (c) Changes in the total area seafloor consumed by subduction, distinguished by the relative contributions from young $(0-40 \mathrm{Myr})$, middle-age $(40-80$ $\mathrm{Myr}$ ), and old (>80 Myr) seafloor. The sum of these contributions is slightly less than the global total (black line) due to some subduction of some seafloor with unassigned ages. The total subduction rate (black line) also differs slightly from the total ridge spreading rate (grey line) because small amounts of continental convergence or divergence offset the seafloor-area budget. 

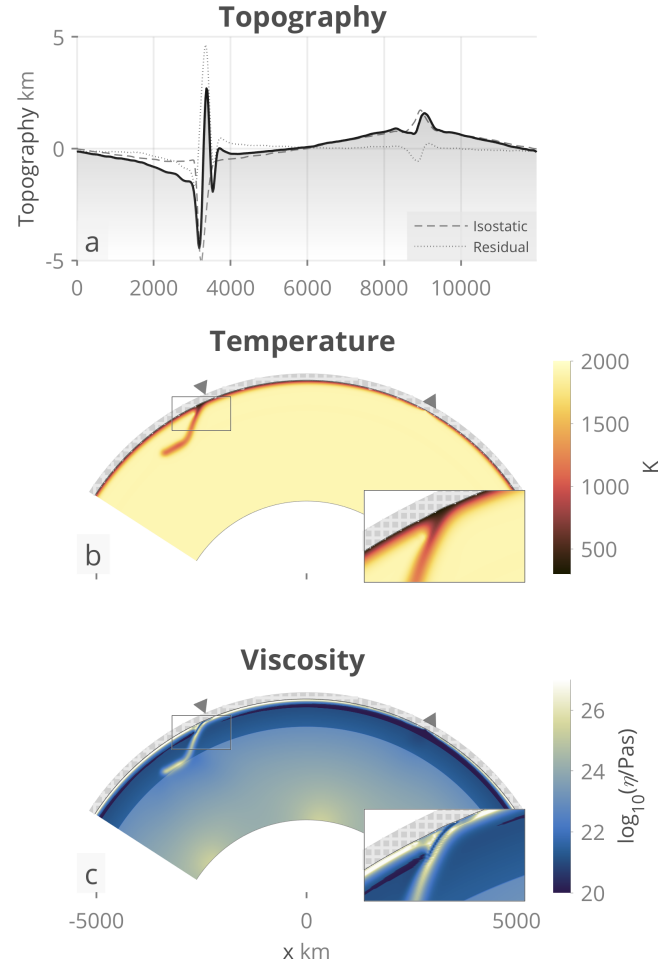
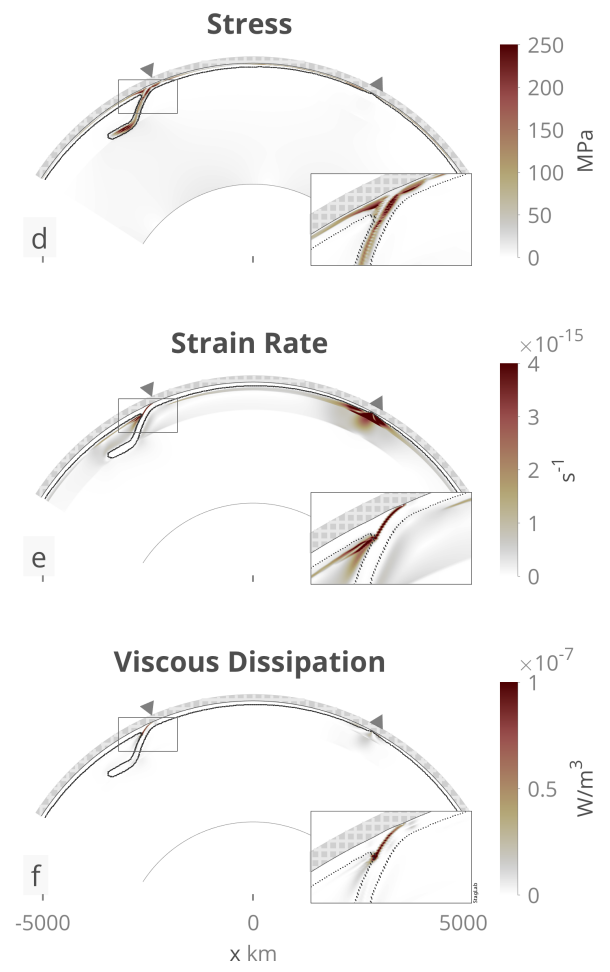

Figure 10: Dynamically self-consistent oceanic-plate model. It includes dynamically self-consistent formation, cooling and destruction. (a) The spreading ridge produces a positive surface topography, while the subduction zone produces a characteristic asymmetric surface topography with regional highs and lows (see Crameri et al. (2017) for more details including model assumptions). (b) While the plate cools gradually at the surface, it will be reheated when sinking back into the mantle. (c) The weak crustal layer is crucial for plate-interface decoupling, allowing for the (d) low-stress, (e) high-deformation zone that enables on-going plate sinking that (f) reduces the resistance from the viscous dissipation. Model performed by the code StagYY (Tackley, 2008) and visualised with StagLab (www.fabiocrameri.ch/software). 

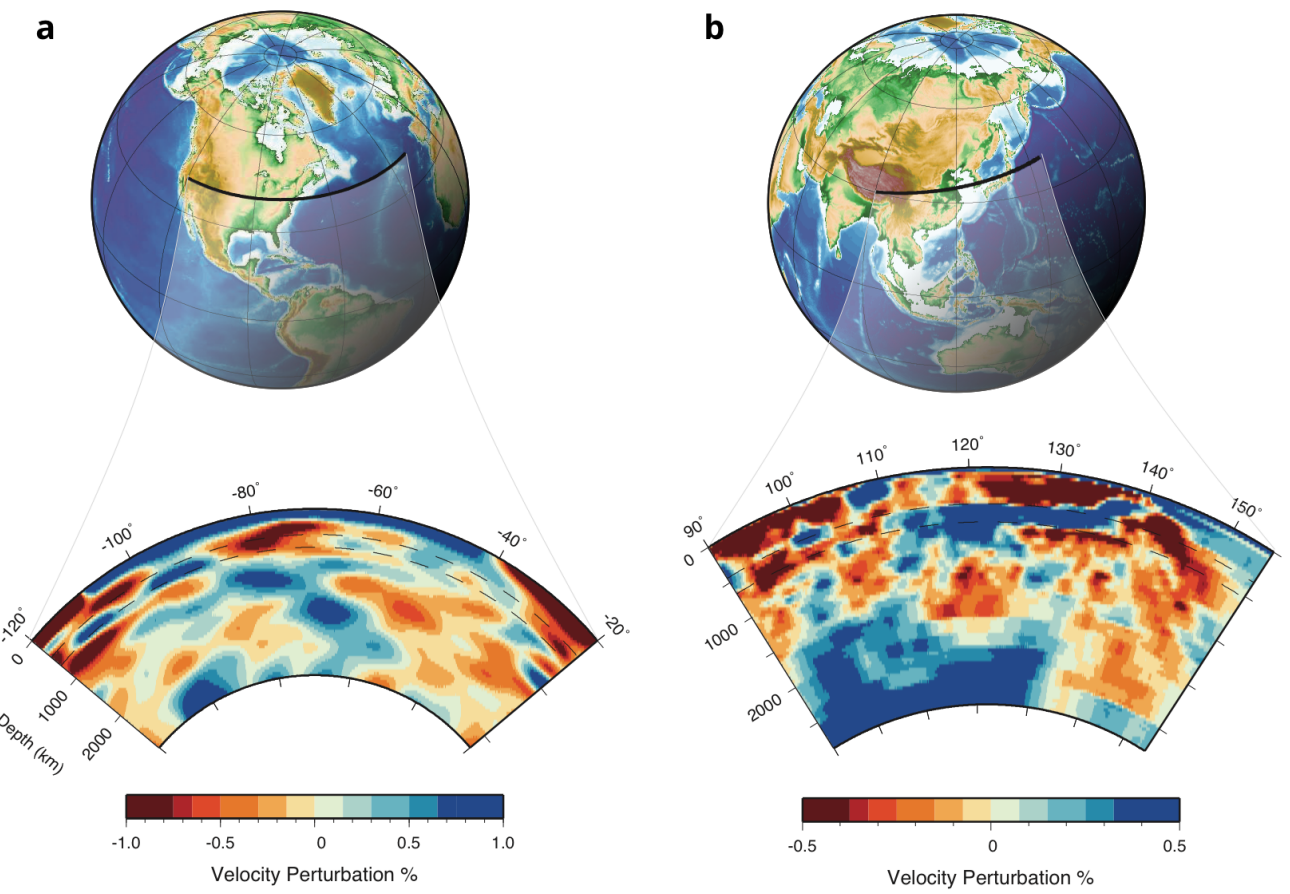

Figure 11: The oceanic-plate graveyard. (a) Farallon slab (blue patches) in the upperand lower mantle as seen through global seismic tomography after Ritsema et al. (2011). (b) Deep subduction near Japan (blue patch) as seen through global seismic tomography indicating intermediate slab stagnation at the upper-mantle transition zone after Li et al. (2008). Note the different colorbar limits. The figure is produced with GMT (www.soest.hawaii.edu/gmt). 


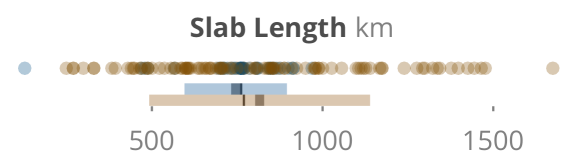

Shallow-Slab Dip ${ }^{\circ}$

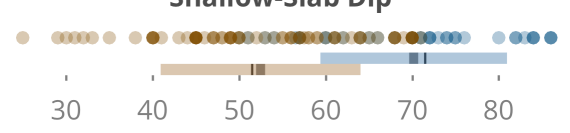

Lower-Plate Velocity $\mathrm{cm} / \mathrm{a}$

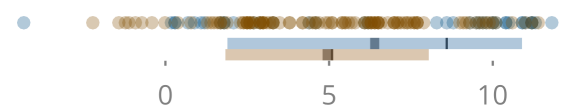

\section{Trench Velocity $\mathrm{cm} / \mathrm{a}$}

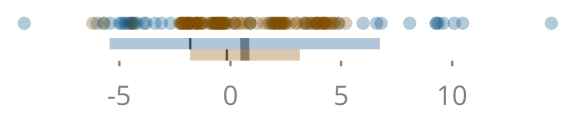

Min. Bending Radius km

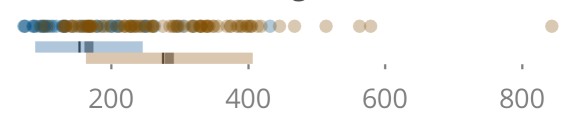

Plate Age Ma
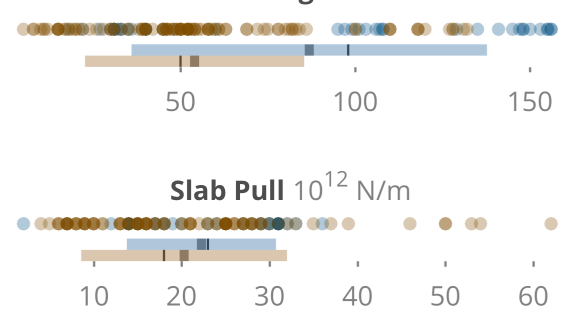

Slab-Descent Rate $\mathrm{cm} / \mathrm{a}$
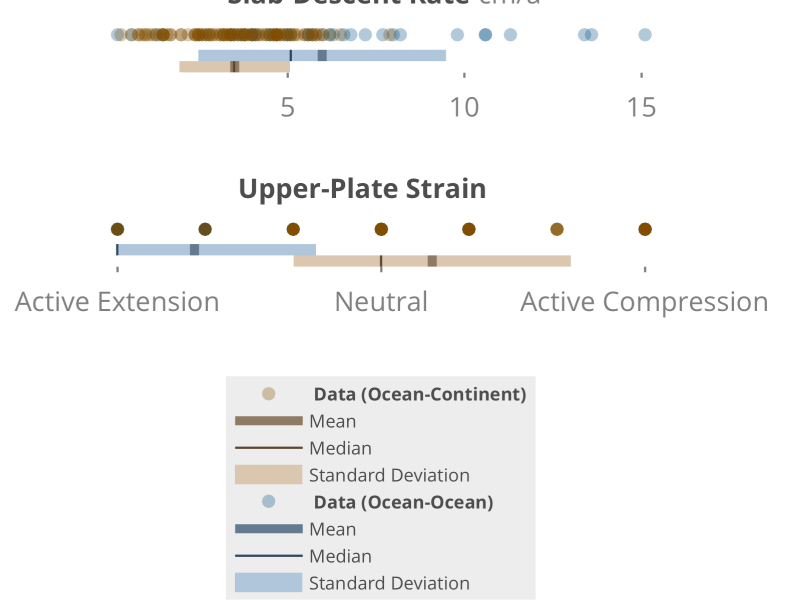

Figure 12: Subduction Diversity on Earth. Shown are individual data points (transparent circles) together with their standard deviation, mean and median for ocean-ocean (blue) and ocean-continent (brown) subduction zones. While the minimum bending radii are compiled from Buffett and Heuret (2011), the remaining data are extracted from the compilation of Lallemand et al. (2005). 


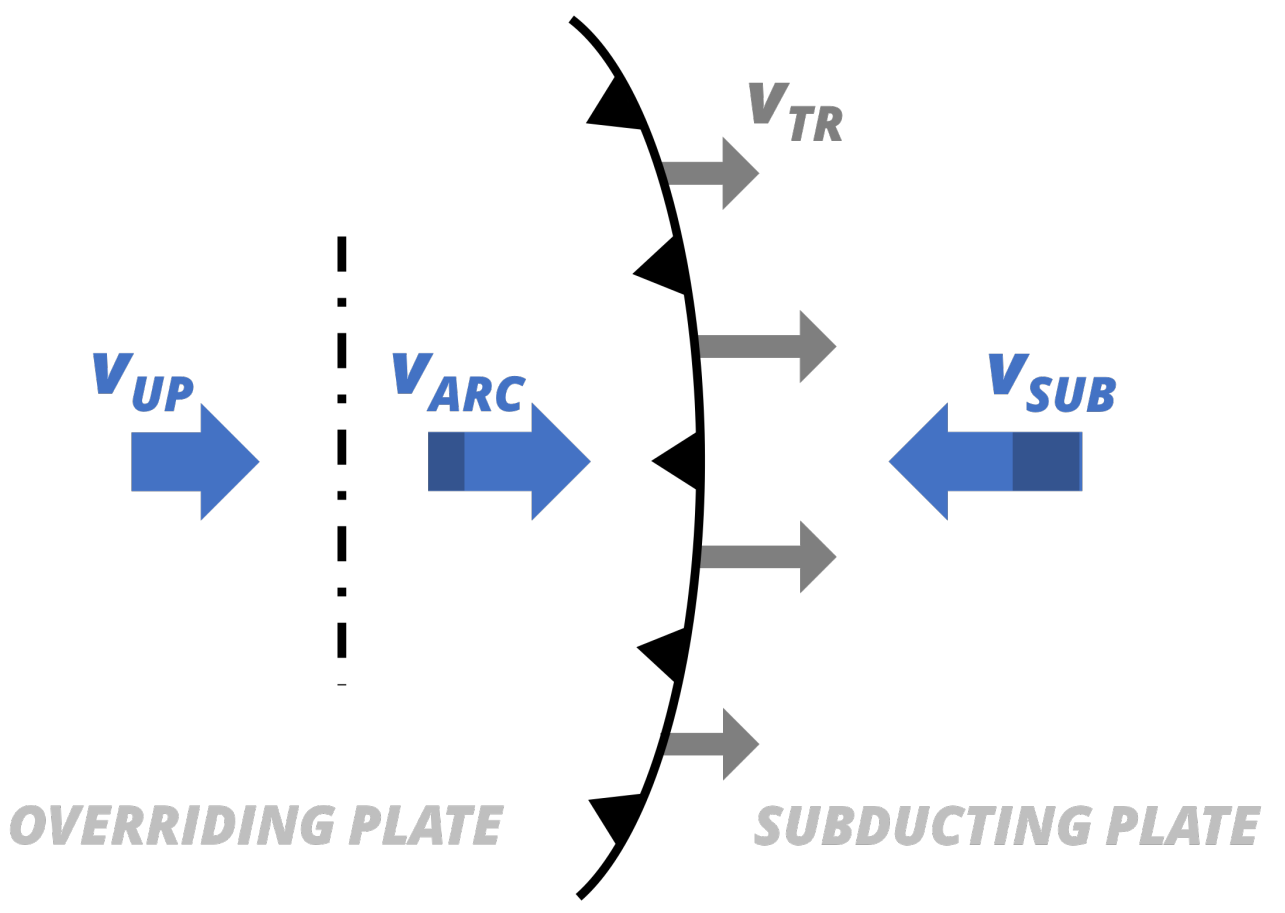

Figure 13: Subduction-zone convergence definitions. Shown are in top view the subducting-plate velocity $\left(v_{S U B}\right)$, the upper-plate $\left(v_{U P}\right)$ and arc velocities $\left(v_{A R C}\right)$ and the trench velocity $\left(v_{T R}\right)$ around a subduction trench (solid black line) and a possible back-arc extension or compression (dashed black line). 